\title{
Revision of European Wormaldia species (Trichoptera, Philopo- tamidae): Chimeric taxa of integrative organisation
}

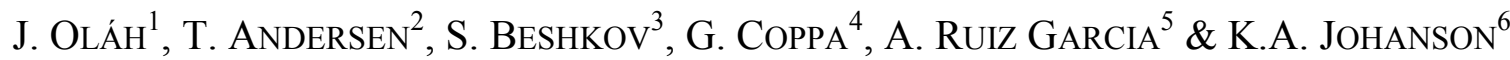 \\ ${ }^{1}$ János Oláh, Residence postal address: Tarján u. 28, H-4032 Debrecen, Hungary,profolah@gmail.com \\ ${ }^{2}$ Trond Andersen, Department of Natural History, University Museum of Bergen, University of Bergen, \\ P.O. Box 7800, N-5020 Bergen, Norway, trond.andersen@um.uib.no \\ ${ }^{3}$ Stoyan Beshkov, National Museum of Natural History, 1 Tsar Osvoboditel Blvd. 1000 Sofia, Bulgaria, \\ beshkov@nmnhs.com \\ ${ }^{4}$ Gennaro Coppa, 1, rue du Courlis, F-08350 Villers-sur-Bar, France, gennaro.coppa@wanadoo.fr \\ ${ }^{5}$ Antonio Ruiz Garcia, Departamento de Sistemas Físicos, Químicos y Naturales (Zoología), Universidad \\ Pablo de Olavide, A-376,Km 1,41013 Sevilla,Spain, aruigar@upo.es \\ ${ }^{6}$ Kjell Arne Johanson, Swedish Museum of Natural History, Department of Zoology, Box 50007, \\ SE-10405 Stockholm, Sweden.E-mail: kjell.arne.johanson@,nrm.se
}

\begin{abstract}
We have recognised significant incongruences among the most commonly used taxonomic characters in the European species of Wormaldia genus of the Philopotamidae caddisfly family. During taxonomical analysis and ranking procedures we have recorded incongruent, discorcordant characters also in the taxa in Rhyacophilidae, Hydropsychidae and Limnephilidae caddisfly families. Based on theoretical background we concluded that taxa of examined caddisflies and probably all living creatures are chimeric entities composed of components of different origin. Genomes and phenomes are tree-like on the surface but more reticulated in the deep. We understand chimerism with universal consequences, expanding well beyond the evolutionary tree-thinking of reductionism and determinism. Taxa are chimeric or at least chimerical in a stochastic universe under the permanent fluxes of the external and internal impacts created by intercourses between entropy and energy gradients. We have surveyed how to create and correct synonymies in the splitter/lumper perspectives along the principles of compositional and specification hierarchies understood as quantitative variability of non-adaptive neutral and qualitative stability of adaptive, non-neutral traits. We outlined how the apophantic (declaratory) hybris creates synonymies and underestimates biodiversity. After redrawing the diverging genitalic structures, particularly the speciation traits we have reinstated species status of eight taxa: $W$. trifida Andersen, 1983 stat.restit, stat. nov., $W$. albanica Oláh, 2010 stat. restit., $W$. bulgarica Novak, 1971 stat. nov., W. daga Oláh, 2014 stat. restit., W. graeca Oláh, 2014 stat. restit., W. busa Oláh, 2014 stat. restit., W. homora Oláh, 2014 stat. restit. W. nielseni Moretti, 1981 stat. nov. Character selection and lineage sorting procedures established the following species groups, species complexes and species clades in the European species of Wormaldia: $W$. occipitalis species group: $W$. occipitalis species complex; $W$. charalambi species group; $W$. copiosa species group; W. triangulifera species group: W. bulgarica species complex, W. khourmai species complex, W. subnigra species complex: $W$. asterusia species clade, $W$. subnigra species clade, $W$. vercorsica species clade; $W$. triangulifera species complex, $W$. variegate species complex. Unplaced species: $W$. ambigua, $W$. algirica, $W$. sarda. In this revision we have described fourteen new species: W. longiseta, W. carpathica, W. kurta, W. parba, W. foslana, W. kumanskii, W. libohova, W. silva, W. gorba, W. kera, W. rona, W. sima, W. granada, W. telva.
\end{abstract}

Keywords. Speciation trait, taxonomic incongruence, chimeric taxa, Wormaldia, new species.

\section{INTRODUCTION}

$\mathrm{T}$ he European representatives of the Wormaldia genus are middle-sized or even smaller species of dull and drab-brown coloured animals, widely populating crenon, hypocrenon and epirithron habitats of headwater streams. They are frequent, therefore important components of the ecological and nature protection studies. But we are unable to identify them reliably to phylo- genetic species level that is to the basic autonomous unit producing and consuming energy in the ecosystems.

Early attempts on fine phenomics in caddisfly taxonomy go back to one of the teachers of the first author in trichopterology, to Dr. Lazare Botosaneanu, and to his studies on the European species of the genus Wormaldia. We dedicate this paper to him. 
We had several stimuli to start a revision on the European Wormaldia species. (1) Evidenced by the very limited knowledge of this so distributed and so abundant genus. (2) Urged by practical need to identify species in environmental samples. (3) Empathized to remember Botosaneanu's first trials in fine phenomics. (4) Scholarly supported by the comprehensive studies and achievement on the endothecal spine patterns of the taxa of "Wormaldia occipitalis" by Neu (2015). (5) Actualised by the outdated atlas of European Trichoptera (Malicky 2004). (6) Provoked by apophantic nature of synonymies created recently on some European Wormaldia species (Malicky 2018).

Our character selecting and analysis in the genus Wormaldia have found significant incongruences among the most commonly used characters. All taxa have mixtures in various rations of ancestral and derived characters (Omland et al. 2008). Endless character trees in a single species tree create radical incongruences between classification and cladistic systems (Grant 2003). Which character tree represents the species tree? We have found various kinds of incongruences in several other caddisfly groups as well. In the Limnephilidae family we have found the speciation trait of paramere to have the most reliable species tree function (Oláh et al. 2018). In Rhyacophilidae family the tree of epiproct shows dissimilar phylogenetic relations compared to gonopod tree. These discordant character trees obscure lineage sorting (Oláh \& Kiss 2018). In a brief survey on character state transformations of the phallic head in the Hydropsychidae family it was confirmed that taxonomic incongruence seems to be a general principle. It is rather a rule, than an exception (Oláh \& deVries 2019).

\section{THEORETICAL DISCOURSE}

According to the Greek myth the chimeric constructs are entities composed of components of different origin. Chimeric living entities have very disparate parts of different origins, like cells, organs, tissues or any structural units from different species. As adjectives the difference between chi- meric and chimerical is that chimeric is like a chimera while chimerical is of or pertaining to a chimera.

Chimerism is supported both by morphological character analysis and by molecular taxonomy. The more we learn about genomes the less treelike we find their evolutionary history due to mosaic pattern of relationships among taxa. They are more network-like expanding well beyond historic tree-thinking (Bapteste et al. 2013). Species are more chimerical than Darwinian, or at least chimeric. Chimerism of incongruences or discordances is created by complex pattern of gene evolution, including incomplete lineage sorting (deep coalescence), gene duplications, gene losses, genom fusion, and lateral gene transfer, admixture of hybridization, introgression and recombination. Incongruence can occur for artefactual reason or for biological reason when gene trees are distinct from each other and from the species tree as well. In prokaryote only a tiny fraction of $1 \%$ of the reconstructed gene trees are congruent with the reconstructed species tree. The same value is roughly $30 \%$ in human genes (Galtier \& Daubin 2008). If chimerism is so common and cannot be dismissed then no any hierarchical universal classification can be taken as natural (Doolittle 1999).

Incongruence between taxonomic and cladistic systems. The dream of taxonomic congruence (Mickevich 1978) that is the similarity in groupings between classifications of the same organisms based on different characters is a naïve wishful byproduct of the evolutionary discourse between phenetics and phylogenetics. The practical consequences of the incongruences between taxonomic versus cladistic systems are deeply frozen in biological systematics (Grant 2003): (1) classification versus cladification; (2) grouping criteria: similarity and differences of taxa versus branching order of clades; (3) paraphyletic groups: accepted versus banned; (4) characters of chromosomal genome versus molecular evidences of cytoplasmatic organelles; (5) empirical versus virtual; (6) hermeneutical character weighting versus overall similarity without hermeneutical 
weighting, especially in molecular cladistics; (7) character state identities versus character state transformations.

Branching versus reticulation. Clonal markers (mtDNA, Y chromosomal DNA) have always shown a high degree of robustness when analysed for hierarchical structures. Contrary, recombining genetic element like the $\mathrm{X}$ chromosome and the autosomes give conflicting information and incongruences from genome region to genome region or from character to character. As a result there is a tension between classifications in terms of nested hierarchies congruent with branching diagrams versus reticulated relations. Genes or characters of organism have different evolutionary history. In bacteria no single gene recovers the same branching pattern. Better to abandon the tree metaphor also in human taxonomy, in reality no such tree exists and theoretically it is useless to strive for one (DeSalle 2016). The tree metaphor of Darwinism, descent with modification, appears only as an apparent virtual tree, the real tree is uprooted, axed, annihilated, trashed or politely buried (Morrison 2014). Incomplete lineage sorting and other 'rogue' data fell the tree of life. There is, however strong belief that reticulation does not invalidate the concept of Tree of Life; in fact it was always reticulate (Mindell 2013). The vertical transfer in combination with speciation creates a tree-like organismal history, while horizontal transfer of hybridization, recombination, introgression, and gene transfer as well as genome fusion create reticulation in that tree. Therefore an emerging alternative metaphor is the network of tree with reticulation (Morrison 2014).

Character trees in species tree. In the persistent evolutionary discourse an inferred phylogeny based on one, more or multitude of characters are taken as given a priori and other neutral or adaptive characters were constrained to follow this branching path as confounding asymmetries of mere passengers (Maddison 2006). These inferred or resolved species trees even with high level of discordance (incongruence) among individual gene trees or trait trees ignore variations in the gene trees used to construct them.
Resolution is realised by assuming that the most common topology represent the species tree applying concatenation or majority-rule methods. Their topology is discordant with the species topology. In hemiplasy the character mapping incorrectly infers the number of times a character has evolved (Hahn \& Nakhleh 2015).

Various internal and external factors affect the vectors and rates of diversification with biases through adaptation and reproductive isolation in the integrative organisation (Oláh et al. 2017). Contrary to our clade constructions, the material organisation is not an inherently selective parsimonious process. Any entity from packages of a few quantums to the human body is composed of multitudes of incongruent trees in an apparent tree. Species trees are built under the permanent constructing/ deconstructing/ reconstructing processes by integrating innumerable and dynamic quantum/gene trees. Character evolution might be correlated with another trait due to shared developmental pathway, pleiotropic effects, linkage disequilibrium and the same trait appears many times in different lineages ( $\mathrm{Ng} \&$ Smith 2014). Discordance between incongruent gene trees and their containing species trees leads to the cloud concept of gene histories (Maddison 1997). It is rather a rule than an exception that the gene trees of gene copies sampled from various species disagree with species phylogeny. This is a direct evidence of chimerism. It seems that any phylogenetic tree is a broad-scale, low resolution view of fuzzy distribution, a cloud of gene histories.

\section{MATERIALS AND METHODS}

We summarize briefly the taxonomic consequences of the apophanticity in creating and supporting synomymies. We detail our principles and applications of the character selection and lineage sorting applying in this revision of the European species of the Wormaldia genus. We have put together our materials and made significant activity to loan type materials available in type depositories listed below. We have organised collecting trips and realised significant sampling field collecting activities to have newly collected specimens available for population studies. 
Depositories. Cantonal Museum of Zoology Lausanne, Switzerland (CMZL); Civic Natural Science Museum "E. Caffi", Bergamo, Italy (CNSMB); Gennaro Coppa Private Collection, France (CPC); Hungarian Natural History Museum, Budapest, Hungary (HNHM); National Museum of Natural History, Sofia, Bulgaria (NMNHS); National Museum, Prague, Czech Republic (NMPC); Naturalis Biodiversity Center, Zoological Museum, Amsterdam, Netherlands (NBCZMAN); Oláh Private Collection, Debrecen, Hungary, under national protection by the Hungarian Natural History Museum, Budapest (OPC); Swedish Museum of Natural History, Stockholm, Sweden (SMNH); The Manchester Museum, University of Manchester, England (MMUE); University Museum of Bergen, University of Bergen, Norway (ZMBN).

\section{Creating and correcting synonymies}

Our new phylogenetic species of incipient caddifly siblings (Oláh et al. 2012, 2013a, b; 2014, 2015, 2016, 2017), delineated by subtle but stable adaptive speciation traits, have inspired a number of papers to synonymize them with unjustified declaratory negation (Malicky 2014, 2018, Sipahiler 2017, 2018). Such ungrounded nomenclatural acts have value as particular personal opinions in science history and might be generated and grounded by various motivations. The resource-depleted and armless taxonomy is still unprepared and fails to realise the resolution power of fine phenomics in searching and recognising speciation traits. These failures feed the pathetic debate of lumpers and frequently accompanied by apophantic synonymies.

Apophanticity. Aristotle's apophantic term is a declaratory statement without examining and evaluating the entities in themselves. This scientific over-reduction in creating synonymies is produced by mixing of scalar compositional hierarchy with vectorial specification hierarchy (Salthe 1991). We revisit the fine phenomics of our synonymised Wormaldia taxa with more comprehensive approach in order to present comparative evidences in more details, badly awaited in this highly neglected genus with unsettled taxa. However, apophanticity is a favourite method of Heidegger against the comparative methods of judging. Comparison obscures the truth, because of placing something in front of something else. His epistemic position is adequate even in the context of our practical problem in creating synonymies among living creatures. If we compare our Wormaldia species in a detailed comparative study to decide about their identity (synonymy) without distinguishing hermeneutically between adaptive and neutral traits we place neutrality in front of adaptability, blinding ourselves in such a way. Therefore, in the present revision we have examined all the available species (mostly types!) of the European Wormaldia genus and clearly distinguished the adaptive traits from the neutral traits that are the head of segment ten together with the endothecal spine pattern as adaptive speciation trait from the neutral traits of the body and other genitalic structures.

Vectorial divergence or scalar variance? Lumpers rely upon similarities and neglect incipient divergences while conflating minor variabilities of vectorial speciation hierarchies with stabilities of scalar hierarchies (Salthe 1991). They are unable to differentiate between adaptive speciation trait of vectorial speciation hierarchy and neutral characters of scalar compositional hierarchy. They rely on gross morphology and looking for similarities of scalar origin rather than for vectorial differences. Our lumper colleagues used to treat the well-discernible contemporary divergences of reproductive barrier building, detected by fine phenomics, routinely, as quantitative variability. Their gross-morphology based inferences are frequently misled and confused in contact zones and clines where various stages of reinforcements are detectable with intermediate forms produced by lateral transfer of crossing and enforced by character displacements. In the disease classification of nosology, the lumpers of psychologists find it easier to recognize similarities than differences, but splitter geneticists encounter with genetic heterogeneity behind. Lumpers in taxonomy focus our attention and provoke the science of fine phenomics and genomics to realise more scientific effort. This is one reason why Darwin wrote: "It is good to have hair-splitters and lumpers" (Burkhardt \& Secord 2016). In a wider and somehow different context 
Sober (2015) exposed the dubious question is the scientific method a myth? Are there principles of scientific reasoning that transcend the boundaries of particular disciplines? Philosophers are mostly normative lumpers with their deductive validity of logical forms. Historians and scientists of various disciplines are more concern about observations, descriptions and conclusions applying different methodologies. Therefore, they are rather splitters, like geneticists as digging deep along particular small topics. But what is the theoretical background behind all of these misunderstandings of complexity?

Lumper/splitter's debate is focused near at the initial splitting point of new emergences. Our new incipient sibling species were delineated mostly by speciation traits of adaptive origin characterized by subtle, but stable divergences enabling us to delineate precise and minute distinctions. Their adaptive shape stability is protected in organised complexes of integrative mechanisms as described in molecular genetics (Oláh \& Oláh 2018). They are reliably detectable by applying the high resolution level of fine phenomics. In contrary, these incipient species have been synonymised just (1) by statements based on inadequate phenomics of gross morphology; (2) by lack of comparative examinations; (3) by declarations of personal opinion; (4) and without studies on type materials. This ungrounded negation is powered more by human hubris and less balanced by scientific devotion to discern the apparently discernibles even by the "lumpers", who give more importance to similarities than to differences in classification.

Human hubris. "Abhimana" (pride, false prestige, selfish conviction) is the function of ahamkara (ego) in Sanscrit. In ancient Greece the "hubris" was one of the greatest human sins. It was understood somehow between overdosed pride and arrogance with abuse, transgression, and the superman attitude of intruding into someone else's sphere, the loss of contact with reality and an overestimation of one's own competence, accomplishments or capabilities. Just opposite to the scientist's attitudes of devotion and humility towards where to cutoff between reality and fantasy. In everydayness of the taxonomy there are few nomenclatural acts creating synonymies without examination of the holotype and without any comparative trait presentations reflecting only simple opinion of unknown grounding. The nomenclatural acts of empty "ex-cathedra" pronouncements are simply declarations without any factual-interpreted (structures, drawings) or without factical-interpreter (hermeneutics) supports. This apophantic (declaratory) assertion, the apophanticity stands blank without aletheia (disclosure, unclosedness, unconcealedness): however there are no facts that exist independent of how scientists perceiving them.

Underestimating biodiversity. Unfortunately this imbalance of lumpers in recognizing the least inclusive taxa, the lower bound of living hierarchy leads to the underestimation of biodiversity. The lumper's attitude and their gross phenomics are not sensitive enough to recognise the most valuable endemic taxa in their homelands. Moreover, the resulted excuse concept of the "widely distributed and highly varying taxa" amplifies a relief background for the wasteful consumption of the biodiversity resources that produces ecosystem services: air, water, soil and food. Humans are accompanied by a biodiversity of over 100 million (Lee 2016), or including prokaryotes one to six billion (Larsen et al. 2017) species and so far we have succeeded to describe only less than two million (Oláh et al. 2015). In the last half century the taxonomy is immobilised and paralysed by the conundrum still dominating between the resolution-limits of DNA molecules and gross morphology. As a result most taxonomists miss to apply the high-tech and high throughput potential of fine phenomics in species delineation. They do not accept and apply in taxonomy the old principle of Liebniz's identity of indiscernibles. Without applying the principles and practices of fine phenomics, we are unable to recognise phylogenetic incipient species; we neglect Liebniz's principle and as a result we underestimate the biodiversity relying simply upon the outdated and overly lumped alpha taxonomy of "adult, "full" or "good" biological species. (Oláh et al. 2015, 2017). We are unable to utilise the adaptive superiority models of the most dynamic and information-rich components of local biodiversity entities. 


\section{Character selection and lineage sorting}

In the common every-day practice of taxonomy the determination and classification of living organisms are based on principles, procedures and methods of semiotics, semiology, semantics and hermeneutics (Oláh et al. 2018). The traditional identification of a single Wormaldia specimen is carried out with arsenals of these sciences, although unconsciously and routinely. In the present taxonomic revision of the European species of the Wormaldia genus we have followed the traditional analytical procedure of character comparison used to delimit species and to delineate higher taxonomical hierarchies.

(1) Character analysis has focused on comparative empirical phenomics of gross and fine structures with simple visual trait matrices, without any statistics, without any modelling algorithms and without any clade computation and construction.

(2) Character selection. For the European species of the Wormaldia genus we have selected six historically studied structures of male genitalia (see below).

(3) Character typing by fixing attributes and recognising its transformational differences.

(4) Character splitting to follow early divergences of initial splits and older divergences of the higher hierarchies with adaptive speciation traits and with non-adaptive neutral traits and with their character combinations.

(5) Character ranking to establish incipient phylogenetic species, species clades, species complexes and species groups applying the principles of commonality, generality, locality, diversity, hierarchy, complexity and parsimony.

Character selection. McLachlan (1865) used the shape of mesal excision on the apical margin of tergite VIII and the form of gonopods as the distinguishing species characters in the Wormaldia genus. Kimmins (1953) has recorded the form of tergite $\mathrm{X}$, cerci and gonopod as well as the armature of the penis as useful characters for the separation of species. In the revision of the Wormaldia occipitalis species group Neu (2015) has used the same characters to delimit species:
(1) excision of tergite VIII, (2) form of tergite X, (3) form of cerci, (4) form of gonopods, (5) endothecal spine pattern. In this revision we have selected six characters to distinguish among taxa.

(1) Dorsal view of the mesoapical excision on tergite VIII, non-adaptive neutral traits with moderate variability. In practice it is difficult to draw the exact profile of the apical margin of the intact three-dimensional tergite VIII. A twodimensional flattening of the entire tergite is difficult to realise.

(2) Lateral view of harpago, the second segment of the gonopod. It is non-adaptive neutral trait with small variability. According to the commonality, generality, diversity, locality, hierarchy and complexity principles the divergences of the gonopods are the oldest among the selected six genital characters. Probably the harpago is the most important ranking criteria to separate the species groups in the European representatives of the Wormaldia genus.

(3) Lateral view of cerci, non-adaptive neutral traits with small variability. Basal and apical region exhibit some limited diversity with basal dilatation and variously shaped rounded or truncated apical head.

(4) Dorsal view of cerci, non-adaptive neutral traits with small variability. Its trait, the extent of the ventromesad turning apex of the cerci is visible reliably in dorsal view.

(5) Lateral view of the head of segment $X$, the "head" is adaptive, non-neutral speciation trait, more diverse and stable than the endothecal spine pattern. The head of segment $X$ is sensitive fine structure and supplied with highly specialised sensory structures of peg and pitted peg sensillae or simply alveoli. The mere presence of these sensory structures indicates the importance of this genital fine structure in sexual integration performing signal function in the development of early stages of reproductive isolation.

(6) Lateral view of the endothecal spine pattern in the phallic organ, adaptive, non-neutral speciation trait, rather stable, but not reliable in routine identification procedure due to the highly variable dispositions of the individual spines. The position of spines is very sensitive to the erection state of the phallic organ. 
Lineage sorting. Due to the theoretically chimeric, reticulated nature of all the living entities any sorting trial in taxonomy is artificial. In reality the nature is chimeric with reticulation in the details, and only apparently diverging in taxonomic hierarchies as a result of the power of integrated organisation. The authonomies of living creatures, maintained by integrative organisation, work against the disintegration of incongruent, discordant stochasticity as they are beingin-the world. Every entity is only an ephemeral structural product of the interaction between disintegration and integration in the course of the accelerating universal expansion and the equilibrating entropy. These apparent divergences, with reticulation behind, create the biodiversity. Therefore in our taxonomical practice we have to continue the tree-like thinking both in classification and in cladistics, but bearing in mind that any trials of classification represent only the surface of reality. The practical solution to stochastic chimerisms is to rely upon various procedures of character combinations with probability perspectives applying majority, supermajority, supramajority or qualified majority rules or total evidence in molecular taxonomy and the old hermeneutics in classical taxonomy with phenomics. The growing interest in the inconsistency in science has reached already our understanding of inconsistent mathematics, paraconsistent logic, metaphysics of science and language (Bueno \& Vickers 2014).

Lineage sorting of the European species of the Wormaldia genus was delineated by character ranking with various character combinations. Applying the selected six characters and their combinations and distinguishing between adaptive and non-adaptive traits, we have found four taxonomical nominal kinds in the the genus.

(1) Incipient phylogenetic species are delimited by the speciation trait that is by the lateral profile of the head of segment $X$.

(2) Species clades in the Wormaldia subnigra species complex of the $W$. triangulifera species group are distinguished by the combination of the lateral shape of the dorsal concavity of the head of segment $\mathrm{X}$ and of the endothecal spine pattern.

(3) Species complexes in the Wormaldia trian- gulifera species group are distinguished by the combination of the lateral profile of the head of segment $\mathrm{X}$ and by the endothecal spine pattern.

(4) Species groups in the European species of the Wormaldia genus are distinguished by the lateral profile of the harpagones.

Established lineages. Based upon the examination of types and freshly collected specimens as well as published drawings we have succeeded to establish the taxonomic position of all European species and included all of them into the linage sorting. However, the placement of some poorly known species without proper drawings is uncertain and, needs future confirmation. Species whose types or freshly collected specimens have been examined directly are indicated by bold letters.

\section{Wormaldia occipitalis SPECIES GROUP}

echinata, joosti, karystia, longiseta sp. nov., taganana.

Wormaldia occipitalis species complex: bosniaca, carpathica sp. nov., cianficconiae, hellenica, juliani, meridionalis, morettii, occipitalis, serratosioi, subterranea, trifida.

\section{Wormaldia charalambi SPECIES GROUP}

charalambi, gardensis, kurta sp. nov., yavuzi.

\section{Wormaldia copiosa SPECIES GROUP}

artillac, botosaneanui, copiosa, corvina, dizkiran, hemsinensis, kakopetros, marlieri, parba sp. nov., pulla, vargai.

\section{Wormaldia triangulifera SPECIES GROUP}

Wormaldia bulgarica species complex: albanica, bulgarica, daga, erzincanica, foslana sp. nov. graeca, kimminsi, kumanskii sp. nov., libohova sp. nov., silva sp. nov.

Wormaldia khourmai species complex: balcanica, busa, gorba sp. nov., kera sp. nov., khourmai, mahiri, rona sp. nov., sima sp. nov.

Wormaldia subnigra species complex:

Wormaldia asterusia species clade: asterusia, homora. 
Wormaldia subnigra species clade: granada sp. nov., mediana, nielseni, subnigra.

Wormaldia vercorsica species clade: gattolliati, ikizdere, malickyi, sukranae, telva sp. nov., vercorsica.

Wormaldia triangulifera species complex: beaumonti, cantabrica, langohri, laticerca, lusitanica, moselyi, saldetica, schmidi, triangulifera.

Wormaldia variegara species complex: arriba, corsicana, maclachlani, mattheyi, numidica, variegata.

Unplaced (incertae sedis): ambigua, algirica, sarda

\section{TAXONOMY}

\section{Wormaldia McLachlan, 1865}

Wormaldia McLachlan, 1865: 140-141: "This genus I have named after Mr. P.C. Wormald, one of the few Entomologists who have paid attention to the Trichoptera. It is allied to Philopotamus, but differs in the form of palpi and in the neuration of the wings, as was pointed out by Dr. Hagen in the Stettin "Entomologische Zeitung" for 1860, p. 279. The species are small and unicolorous."

The Wormaldia genus, a distinctly apomorphic lineage in the ancestral Philopotaminae subfamily has all trace of $2 \mathrm{~A}$ on hindwing almost disappeared and resulted in the appearance of anal veins as a divergent fork (Ross 1956). Its representatives are widespread both in the Old and the New Worlds. In the present survey we have established the lineage position of all the known European species of the Wormaldia genus, except three unplaced species, with brief characterization of the newly established species groups, species complexes and species clades. New drawings were prepared without any further taxonomical evaluation for all the examined species applying identical drawings style and drawing details including (1) left lateral profile of the entire genitalia without phallic organ; (2) left lateral profile of the head of the segment $X$ for several specimens or several drawings from the single specimen; (3) lateral view of the phallic organ with the endothecal spine pattern; (4) dorsal view of the segment $X$ and the cerci; (5) dorsal view of the apical margin of tergite VIII with the mesal excision. Besides the description of new species and taxonomical treatment of little-known ones we have evaluated and treated all the apophantic and invalid synonymies.

\section{Wormaldia occipitalis species group}

This species group is characterized by the combination (1) of the parallel-sided, not tapering harpago with rounded head, (2) of the terminal of segment X with capitate "head" and with pronounced dorsal subapical pointed process and (3) of the endothecal spine pattern with the presence of various clusters of small spines and with variously shaped and sized spines.

\section{Wormaldia echinata Tobias, 1995}

(Figures 1-3)

Material examined. France, Alpes-Maritimes, Moulinet, La Bevera, 9.X.2006, leg. G. Coppa (1 male, OPC).

Remarks. Based on the older divergences of gonopod Wormaldia echinata having parallelsided harpago belongs to the $W$. occipitalis species group. However, the "head" is more elongated compared to $W$. occipitalis species complex, almost similar to the $W$. subnigra complex of the $W$. triangulifera group. There is an elongated, very long cluster of small spines, a character present only in the $W$. bulgarica and $W$. khourmai species complexes of the $W$. triangulifera species group. There are three different incongruent, discordant or chimeric character trees of the harpago, the head and the long small spine cluster. The ranking principles of generality, diversity and locality relate $W$. echinata to the $W$. occipitalis species group by the parallel-sided harpago. 


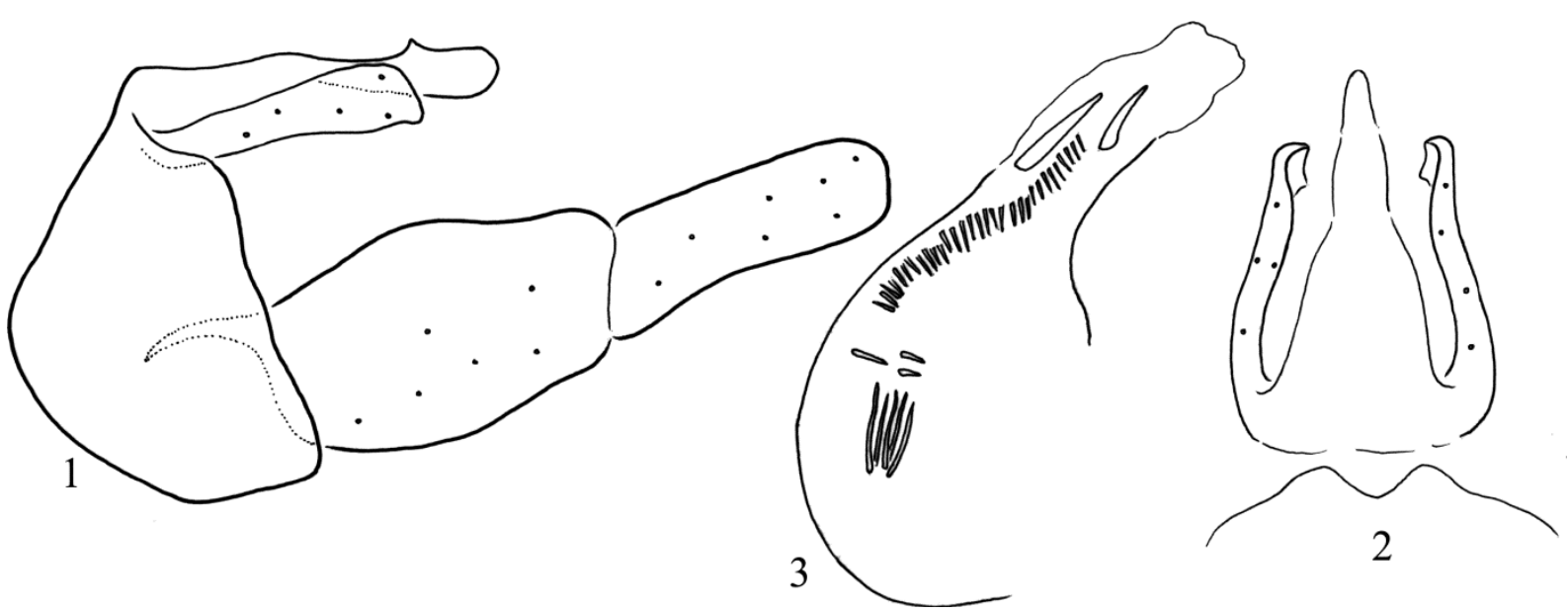

Figures 1-3. Wormaldia echinata Tobias, 1995. 1 = male genitalia in left lateral view, 2 = mesal excision on tergite VIII and segment $\mathrm{X}$ with cerci in dorsal view, 3 = phallic organ with the endothecal spine pattern in left lateral view.

\section{Wormaldia joosti Kumanski, 1980}

(Figures 4-6)

Material examined. Holotype: Russia, Western Caucasus, northern slopes, basin of Teberda river, spring brooklets, tributaries of the Karakel lake, 17.VI.1976, leg. Mrs. and Mr. Wolfgang Joost (1 male, NMNHS). Allotype: same as holotype (1 female, NMNHS). Paratype: same as holotype (1 female, NMNHS). Georgia, Svanetia, brook, left tributary of Mulkhura riv. SE of Mestia, $43^{\circ} 02.5^{\prime} \mathrm{N} 42^{\circ} 45.8^{\prime} \mathrm{E} ; 1500 \mathrm{~m}$, 5.VII.2013, leg. P. Chvojka (1 male, NMPC).

Remarks. Based on the older divergences of gonopod Wormaldia joosti having parallel-sided harpago belongs to the $W$. occipitalis species group. The "head" is elongated, very long and concave dorsad compared to the $W$. occipitalis species complex. The elongate and concave head is similar to the $W$. subnigra complex of the $W$. triangulifera group. There are two different incongruent, discordant or chimeric character trees of the harpago and the head. The ranking principles of generality, diversity and locality relate $W$. joosti to the $W$.occipitalis species group by the parallel-sided harpago.

\section{Wormaldia longiseta Coppa \& Oláh, sp. nov.}

(Figures 7-9)

Material examined. Holotype, France, Lozère department, Cocures, river le Briançon, $3^{\circ} 36^{\prime} 45^{\prime \prime} \mathrm{E} ; 4^{\circ}$
21'28"N, 600 m, 27.V.2017, leg. G. Coppa (1 male, CPC).

Diagnosis. Having parallel-sided harpago $W$. longiseta sp. nov. belongs to the Wormaldia occipitalis species group and having no complex endothecal spine system this new species is not a member of the $W$. occipitalis species cluster. It is a unique species characterized by the elaborated network of small spine clusters composed of thin and long setae.

Distinguishing diagnosis. This species is delineated by the character combination detailed below. Easily delimited and recognised by the unique innovation of the dense and extended clusters of slender, elongated setae in the endothecal spine pattern of the phallic organ.

Description. Male (in alcohol). Medium-sized light brown animal. Sclerites medium brown, setal warts both on head and thorax and legs brown. Maxillary palp formula is I-II-IV-III-V. Forewing length $4 \mathrm{~mm}$. Spur formula is 244 .

Male genitalia. Segment X characterized by narrow parallel-sided apex in dorsal view, and by a dorsal small pointed subapical process visible in lateral view; apex elongated plum-shaped in lateral view; the ending is armed with sensory structures of sensilla basiconica (pegs) or sensilla coeloconica (pitted pegs) both on the very dorsal 
ending of the narrowing apex as well as on the sublateral broadening. Cerci slender with slightly pointed apex. Gonopods very produced, coxopodite and harpago with equal length; harpagones parallel-sided in lateral view. Phallic organ with eversible membranous endotheca containing an elaborated network of clusters composed of very thin and long setae.

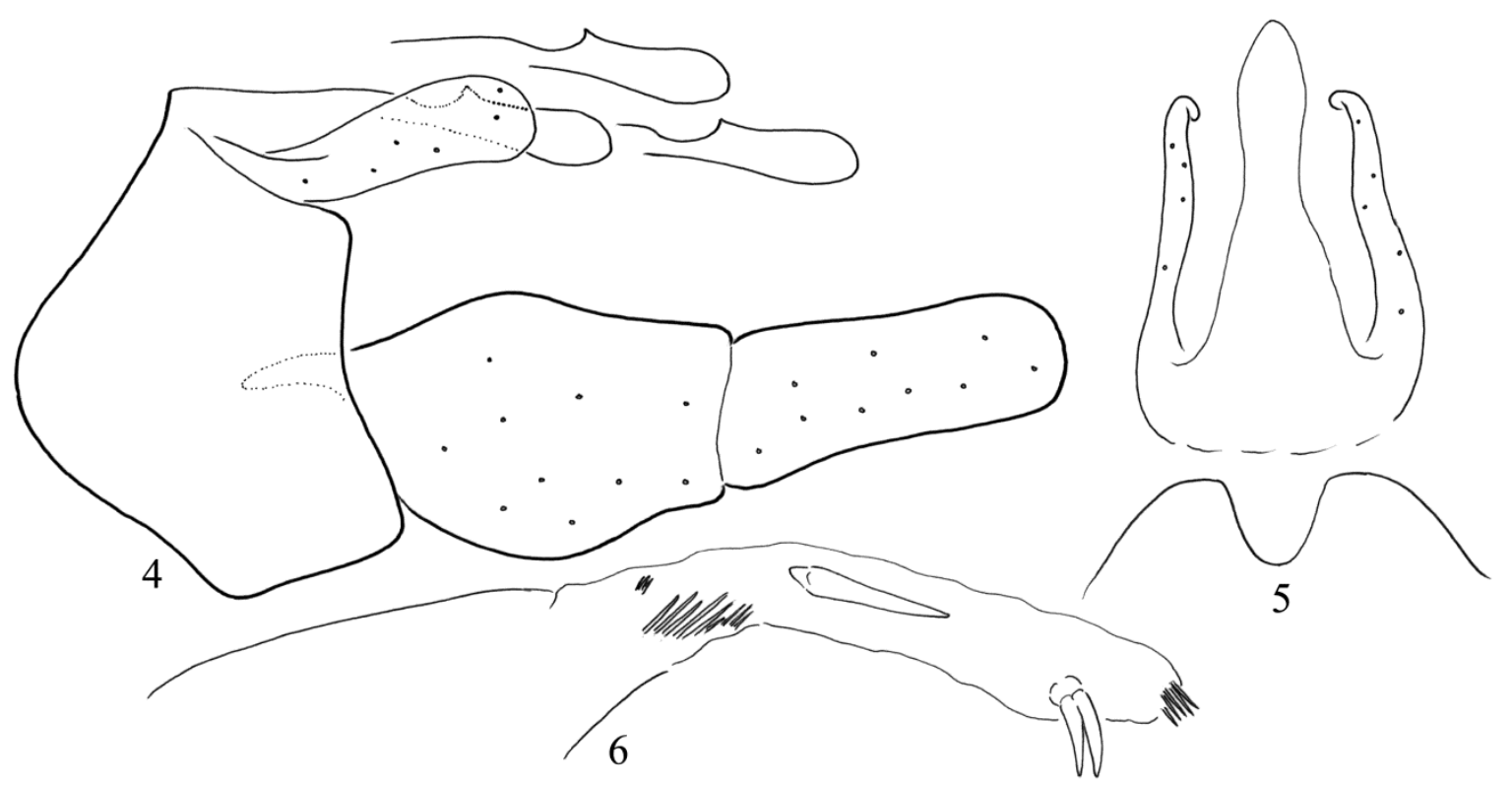

Figures 4-6. Wormaldia joosti Kumanski, 1980. 4 = male genitalia in left lateral view, $5=$ mesal excision on tergite VIII and segment $\mathrm{X}$ with cerci in dorsal view, $6=$ phallic organ with the endothecal spine pattern in left lateral view.

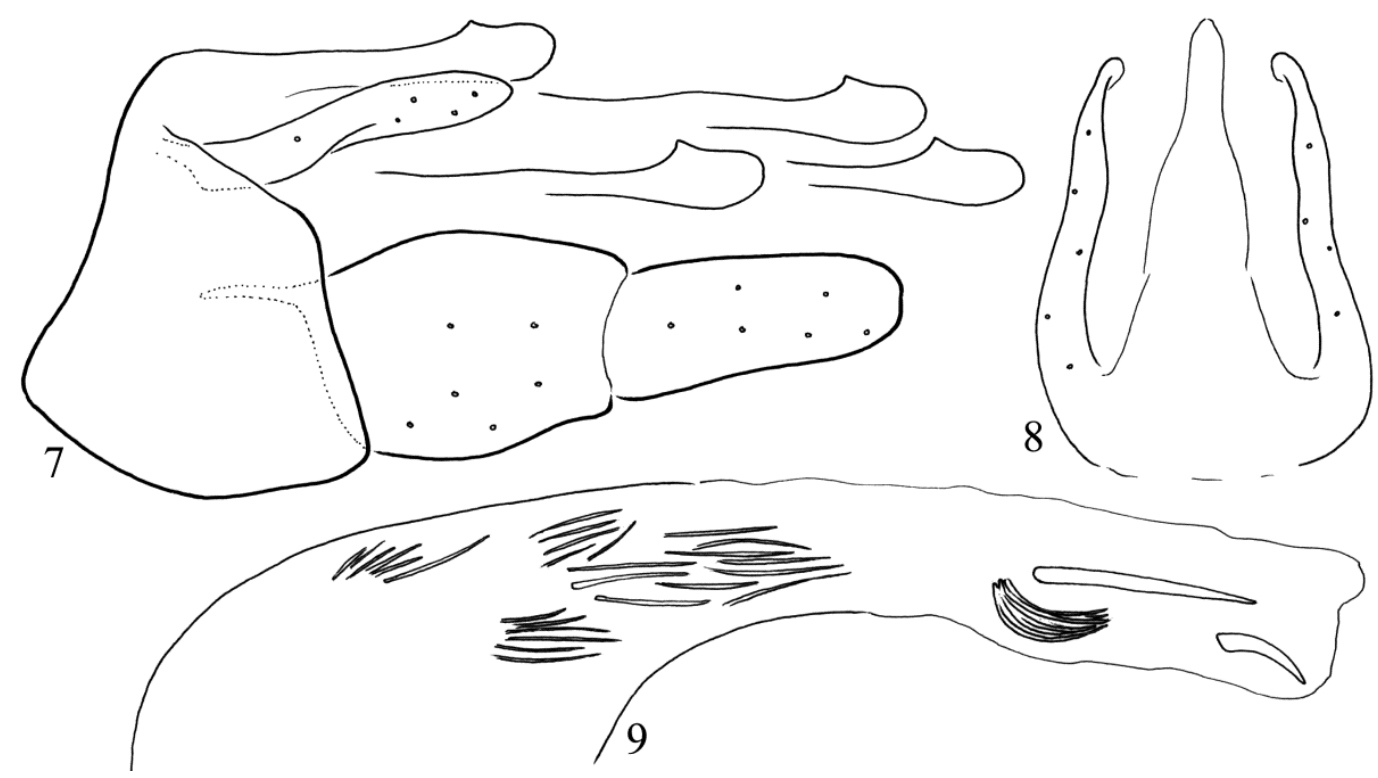

Figures 7-9. Wormaldia longiseta Coppa \& Oláh, sp. nov. Holotype: $7=$ male genitalia in left lateral view, $8=$ segment $\mathrm{X}$ with cerci in dorsal view, $9=$ phallic organ with the endothecal spine pattern in left lateral view. 
Character combination. (1) Dorso-subapical point of segment $X$ tiny, visible in lateral profile as the top point formed by the apical right-angle of the dorsal concavity. (2) Apex of segment X perfectly horizontal and elongated semicircular, plum-shaped. (3) Apex of cerci pointed. (4) Ventromesal projection of cerci less developed. (5) Harpagones parallel-sided. (7) Slender and long basal spines lacking. (8) Proximal pair of clusters of small spines lacking. (9) Distal pair of clusters lacking. (10) Two stout spines present. (11) Arching cluster of small spine developed.

Etymology. longiseta, with reference to the presence of elongated slender spines composing the elaborated spine clusters in the endotheca of the phallus.

\section{Wormaldia occipitalis species complex}

In Europe every trichopterologists has treated Wormaldia occipitalis as a highly variable and widely distributed species. Most of us have identified this very abundant component of headwaters with some hesitation and put aside them for a more detailed future study in order to find reliable character states for species delineation.

This species complex is characterized with rather complicated pattern of spine system organised in integrative processes on the everted surface of the eversible endotheca as detailed already by Botosaneanu more than half century ago (1960a,b). Recently Neu (2015) has given particular attention to the character state transformations of the endothecal spine pattern participating in species divergences and helping taxonomists in species delineations. Here we follow his grounding discoveries.

Species delineation by endothecal spine pattern. In practice, after clearing and cleaning, the endotheca are visible usually in virgin or various non-virgin stages of reverted, intruded, invaginated, retracted position depending on the individual functional mating and/or copulating histories. The endotheca resting in the retracted position inside the phallotheca is only very seldom visible in a fully everted, extruded, protruded, evaginated position. Most frequently the position of endotheca is unstable varying around reverted condition, partially invaginated or evaginated. The everted tip slender spines are basal spines in reverted position. The everted basal stout spines are tip spines in reverted position. The everted middle clusters of small spines remain middle also in reverted position. Neu (2015) applied the everted position however, in practice usually we face the reverted position; therefore here we apply the reverted position to locate the components of the endothecal spine system. We have to emphasize that the position of spines are very dynamic depending on the actual condition of the endotheca. Every individual specimen has its own arrangement pattern of the same five spine components. The particular locations of the individual spines or the degree of disintegration of spine clusters are highly sensitive to the copulation history as well as to the invaginated-devaginated state of the endotheca. Beside, the location and desintegration instability, the diagnostic application of the endothecal spine pattern is further complicated by the spine losses occurring during functional copulatory processes. Moreover, to locate successfully the particular component of the spine system requires proper clearing and cleaning procedure, high microscope resolution and experienced careful examination with several viewing angles. Bearing in mind all of these shortcomings, the endothecal spine pattern has primary diagnostic value.

Coding the reverted pattern of endothecal spine components. There are four types of spines. (1) Slender spines: they are long and basal in the anterior part of the reverted endotheca, located very near to the apical opening of the short tubelike endothecal sclerites; in most species (bosnia$c a$, carpathica, occipitalis, subterranea) they are represented by a pair or three (only at hellenica) of slender long spines, occasionally duplicated, seldom triplicated, but variously adhering basad; in hellenica the three slender basal spines (triplet) also prone or liable to dublicate or triplicate; juliani and morettii lack distinct slender spines; these slender and long basal spines are the most 
variable components of the spine systems. (2) Clusters (bundle, bunch) of small spines located usually in middle position; there are four such clusters: a pair of proximal (anterior) clusters and a pair of distal (posterior) clusters; the number of small spines in the clusters is variable with specific ranges; the clusters are liable to disintegrate, depending on the intensity of copulations; (3) Stout spines: there are three spines (triplet), usually one long and two short located middle or apicad or in tip position; the most stable component of the spine system. (4) Specialised cluster of small spines; the fifth cluster present in 3 species; discovered by Neu (2015) as appearing during eversion on the tip of a small endothecal side lobe (occipitalis) or apical lobe (juliani) as well as a single cluster composed of many densely packed very thin black spines (bosniaca).

\section{Wormaldia bosniaca Botosaneanu, 1960}

(Figures 10-12)

Wormaldia occipitalis bosniaca Botosaneanu, 1960a: 273-274, "s'en distingue pourtant par la présence de 5 touffes d'épines (celle apicale, k, composée d'un très grand nombre de très fines épines, manque chez occipitalis occipitalis, et, semble-t-il aussi chez o. subterranea Rad.), puis par le grand nombre d'épines composant les autres 4 touffes $\mathrm{d}, \mathrm{c}, \mathrm{f}, \mathrm{e}$ - (environ 10-17 pour chaque touffe); quant à l'aspect et à la position des grosses épines (a,b,g,h,i), ils correspondent assez bien à ce que nous savons d'occipitalis occipitalis (observer pourtant des trois branches de l'épine a). Gonopodes comme chez o. occipitalis, $\mathrm{X}^{\mathrm{e}}$ segment comme chez o. subterranean, mais appendices supérieurs arrondis à l'apex. Je pense qu'il s'agit d'une nouvelle sous-espèce, que je vais dénommer bosniaca n. ssp. $1 \delta^{\lambda}$ et $1 q$ de Trebevic ont été désignés comme holotype et allotype (Fernand Schmid); 1 त parat.: Deutsches Entomologisches Institut, Berlin; 1 đo parat.: Lazare Botosaneanu."

Wormaldia bosniaca Botosaneanu, 1960a: Malicky 2005:549, Unclear taxonomic position.

Wormaldia bosniaca Botosaneanu 1960a: Neu 2015: 107, Raised to species rank.

Material examined. Bosnia-Herzegovina, Sutjeska National Park, Klobučarica stream, left tributary of
Sutjeska River, 2.IX.1988, singled leg. J. Oláh (12 males, OPC). Sutjeska National Park, first spring stream at Sutjeska River, 2.IX.1988, singled leg. J. Oláh (23 males, OPC). Sutjeska National Park, second spring stream at Sutjeska River, 2.IX.1988, singled leg. J. Oláh (41 males, OPC). Sutjeska National Park, small tributary of Sutjeska River, 1.IX.1988, singled leg. J. Oláh (3 males, 3 females; OPC). Jablanica, first spring stream, 4.IX.1988, singled leg. J. Oláh (4 males, OPC). Jablanica, second spring stream, 4.IX.1988, singled leg. J. Oláh (4 males, OPC).

Distinguishing diagnosis. This species is delineated by the character combination detailed below. Easily delimited by the combination of the perfectly horizontal and plum-shaped semicircular slightly elongated apex of segment $X$ and of the pronounced presence of the fifth specialized spine cluster composed of many and densely packed small black spines.

Character combination. (1) Excision on tergite VIII deep and wide. (2) Dorso-subapical point of segment $\mathrm{X}$ tiny, visible in lateral profile as the top point formed by the apical right-angle of the dorsal concavity. (3) Apex of segment X semicircular. (4) Apex of cerci rounded. (5) Ventromesal projection of cerci lacking. (6) Harpagones parallel-sided. (7) Slender and long basal spines organized in a pair, each frequently doubled or tripled. (8) Proximal pair of clusters of small spines short. (9) Distal pair of clusters longer. (10) Three stout spines present. (11) Specialised fifth cluster of small spines very produced.

Variability. We have examined six populations from the Sutjeska National Park and found the lateral profile of the apex of segment $X$ rather stable. However, we have collected three specimens from near the locus typicus representing a mixed population with highly varying apex of segment $X$ and spine pattern.

Contact zone. As detailed at Wormaldia subterranea presentation we have found mixed populations of $W$. bosniaca and $W$. subterranea in Bosnia-Herzegovina along the Neretva Valley with intermediate hybrids having shortening head of segment $X$ and without the fifth dense cluster composed of many thin spines. 


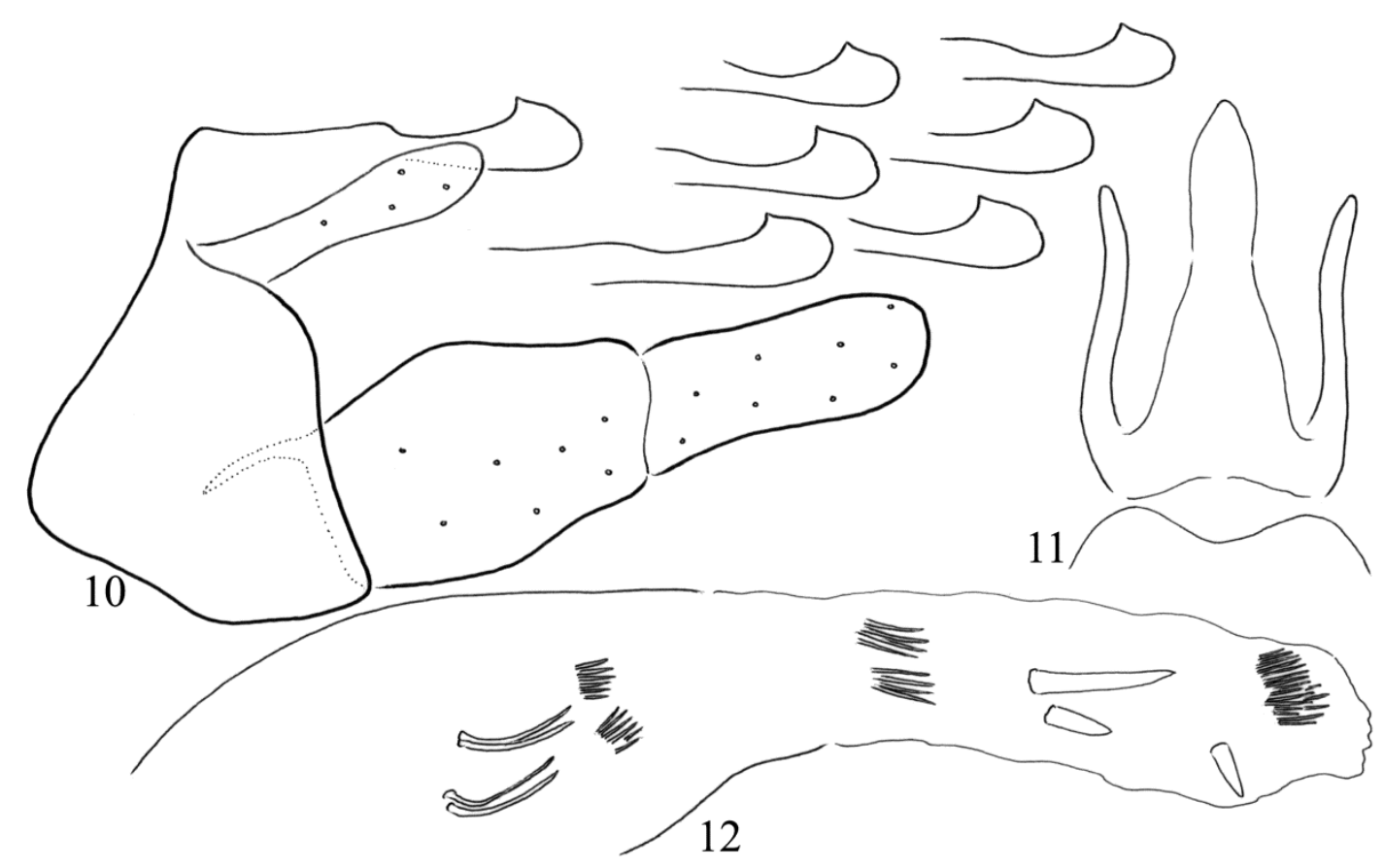

Figures 10-12. Wormaldia bosniaca Botosaneanu, 1960. $10=$ male genitalia in left lateral view, $11=$ mesal excision on tergite VIII and segment $\mathrm{X}$ with cerci in dorsal view, 12 = phallic organ with the endothecal spine pattern in left lateral view.

\section{Wormaldia carpathica Oláh, sp. nov.}

(Figures 13-15, 16-67)

Material examined. Holotype: Hungary, Zemplén Mts., Kemence Valley, small streams, 4-5.IX.1984, singled leg. J. Oláh (1 male, OPC). Pratypes: same as holotype (23 males, 6 females, OPC). Albania, Tiranë, SW slopes of Dajti Mt., 22.VI.1994, leg. P. Chvojka (40 males, 17 females, NMPC; 3 males, OPC). Albania, Malësia e Tiranës (Highlands of Tirana), below Maja e Fekenit (=Feken peak), west from Qafa e Selitës pass, N4122'12", E01959'11", $1100 \mathrm{~m}, 12$.VIII. 2018, leg. S. Beshkov A. Nahirnic \& C. Plant (2 males, OPC). Bulgaria, Berkovitsa Province, Stara Planina, Berkovitsa, stream E of Kom settlement, $1590 \mathrm{~m}$,

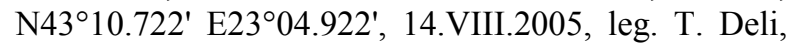
Z. Eröss, Z. Fehér, D. Murányi (1 male HNHM). Bulgaria, Ossogovo Mts below Ruen (= Autotransport) chalet, above Kyustendil town $1505 \mathrm{~m}$., N42 $10^{\prime} 28^{\prime \prime}$, E022 37'56.5", 23.IX.2018, at lamps, light traps leg. S. Beshkov \& A. Nahirnic (22 males, OPC). Czech Republic, SE Moravia, Bílé Karpaty Mts., spring area,

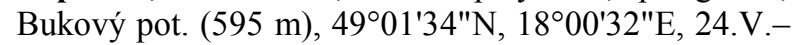
23.X.2010, leg. P. Chvojka (25 males, 19 females, NMPC; 6 male, OPC). Czech Republic, SE Moravia, Bílé Karpaty Mts., spring area $2 \mathrm{~km}$ SE Nová Lhota-
Vápenky, 4851'42"N, 17³9'07"E, $265 \mathrm{~m}, 7 . V I .-$ 27.X.2005, leg. P. Chvojka, mixed population with $W$. subterranea (69 males, NMPC; 12 males, OPC). Hungary, Börzsöny, Diósjenő, Kemence patak, 700 m, 3.V.2006, leg. D. Murányi (1 male, HNHM). Mátra Mts., Mátraháza, 30.VII.1938, leg. J. Sátori, identified as Wormaldia trianulifer by J. Sátori (14 males, 4 females; OPC). Hungary, Mátra Mts., Parádfürdő, 11.VII.1941, leg. J. Sátori, identified as Wormaldia trianulifer by J. Sátori (1 male, OPC). Hungary, Mátra Mts., Galyatetö, Lengyendi stream, 15.VII.1983, leg. J. Oláh (3 males, 1 female; OPC). Hungary, Mátra Mts., Szuhai stream, 15.VII.1983, leg. J. Oláh (1 male, OPC). Hungary, Mátra Mts., Csörgő stream, 14.VII. 1983, leg. J. Oláh (1 male, OPC). Hungary, Mátra Mts., Galyatető, Feketetó forrás, 17.IX.1986, leg. Á. Uherkovich \& S. Nógrádi (1 male, OPC). Hungary, Bükk Mts., Szentlélek, small stream with lime tuff steps, 7.X.1964, singled leg. J. Oláh (3 males, OPC). Hungary, Bükk Mts., Nagyvisnyó, Bán Valley, 18.IX. 1985, leg. Á. Uherkocich (1 male, OPC). Hungary, Zemplén Mts. Kökapu, Kemence stream, 7.VIII.1987 leg. J. Oláh (12 males, OPC). Hungary, Zemplén Mts., Ördög Valley, small stream, 10.VIII.1966, singled leg. J. Oláh (2 males, 1 female; OPC). Hungary, Zemplén Mts., Lászlótanya, small stream, 20.VI.1983, light leg. J. Oláh (2 males, 1 female; OPC). Hungary, Zemplén 
Mts., Lászlótanya, small stream, 24.VII.1985, singled leg. J. Oláh (6 males, 1 female; OPC). Hungary, Zemplén Mts. Füzér, Nagy stream, 12.VII.2005, leg. Papp \& Földváry (4 males, HNHM). Macedonia, Southeastern region, Plavuš Hills, Valandovo, forest brook at Motel Izvor, $\mathrm{N}$ of the city, N41 ${ }^{\circ} 19.636^{\prime}, \mathrm{E} 22^{\circ} 33.327^{\prime}, 260 \mathrm{~m}$, 06.05.2014, T. Kovács, D. Murányi (1 male, 2 females; OPC). Macedonia, Southwestern region, Jablanica Mts, Vevčani, Vevčani Springs and outlet stream at the city, N41 14.371', E20³5.056', $935 \mathrm{~m}, 26.06 .2014$, P. Juhász, T. Kovács, D. Murányi (1 male, OPC). Poland, Western Carpathians, Silesian Beskids,Biala Wiselka Valley, 26.VIII.1986, singled leg. J. Oláh (6 males, 1 female; OPC). Poland, Gorce Mts., Kamienica stream, 26.VII. 1985, singled leg. J. Oláh (1 male, OPC). Romania, Cindrel Mts. Paltinis, stream Daneasa, N45 41.999' E23 53.527', 726m, 29.V.2013, singled leg. J. Oláh, E. Bajka, Cs. Balogh, \& G. Borics (1 female, OPC). Romania, Apuseni Mts. Garda de Sus, tributary of Ariesul Mare, N46 270.493' E22 47.895', 788m, 29.V.2013, singled leg. J. Oláh, E. Bajka, Cs. Balogh, \& G. Borics (35 males, 2 females; CNSMB). Romania, Apuseni Mts. Vartop, spring streams, N46 31.045' E22 39.821', 1209m, 29.V.2013, singled leg. J. Oláh, E. Bajka, Cs. Balogh, \& G. Borics ( 4 males, 2 females; OPC). Romania, Apuseni Mts. Garda de Sus, tributary of Ariesul Mare, N46²70.493' E22 ${ }^{\circ} 47.895^{\prime}, 788 \mathrm{~m}$, 20.VI.2013, singled leg. J. Oláh, Cs. Balogh, \& S. Fekete (47 males, 39 females; OPC). Romania, Apuseni Mts. Vartop, spring streams, N46 $31.045^{\prime}$ E22³9.821', 1209m, 20.VI.2013, singled leg. J. Oláh, Cs. Balogh, \& S. Fekete (3 males, 2 females; OPC). Romania, Apuseni Mts., Vladeasa Mt., Jada stream, Iedulului triburaty, Saritoarea Iedulului Waterfall, N: 46² 42'42.2' E: 22³5'04,9", 950m, 3.VII.2013, leg. Cs. Balogh, (4 males, 1 female, OPC). Romania, Apuseni Mts., Bihor Mt., Crisul Pietros, Valea. Sebiselu, N: 4636'56,61" E: 22²9'16,68”, 518m, 4.VII.2013, leg. Cs. Balogh, (2 males, 6 females; OPC). Romania, Apuseni Mts., Bihor Mt., Crisul Pietros, Valea. Aleului, N: 46³8'24,3" E: 22³6'27,9", 634m, 4.VII. 2013, leg. Cs. Balogh, (2 males, 1 female; OPC). Romania, Retezat Mts., tributary of Cerna stream, 1208m, N: 45¹3'10.39" E: 2250'24.17", 12.VII.2013, leg. E. Bajka, Cs. Balogh, G. Borics, P. Borics, (3 males, 4 females; OPC). Romania, Apuseni Mts. Garda de Sus, tributary of Ariesul Mare, N46²7'30.23"'” E: 22०47"55.15" 788m, 22.VIII.2013, singled leg. Cs. Balogh (6 males, 9 females; OPC). Romania, Apuseni Mts. Bihor Mt. Baita, Baita Plai, tributary Crisul Baita, N: 46²8'52.10" E: 22³6'10.03", 507 m 15.05.2014, leg. Cs. Balogh \& B.V. Béres (3 males, 1 female; OPC). Romania, Apuseni Mts. Bihor Mts. Bubesti-
Cobles, tributary P. Cobles, N: 46²9'56.08" E: 2243'48.64" 902 m, 14.05.2014, leg. Cs. Balogh \& B.V. Béres (1 males, OPC). Romania, Apuseni Mts. Muntii Gilaului, Statiunea Muntele Baisorii, La Mocirle, spring streams, N46 ${ }^{\circ} 30.241^{\prime}$ E23 $3^{\circ} 15.550^{\prime}$, 1552m, 4.IX.2015, singled leg. M. Kiss, J. Oláh \& L. Szél (40 males, OPC). Romania, along Transalpina (67C) road, $3 \mathrm{~km}$ downstream of Oasa Reservoir, 29.VI.2016, singled leg. J. Oláh \& J. Oláh jr. (5 males, 1 female; OPC). Romania, Maramures Mts. Viso stream, tributary, 15.V.1993, leg. J. Oláh (8 males, OPC). Romania, Maramures Mts. Rona stream, 12.VIII. 1993, light leg. J. Oláh (9 males, 4 females; OPC). Romania, Muntii Rodnei, Statiunea Borsa, (Borsabánya) 900m, 6.VIII.1942, leg. J. Sátori (1 male, OPC). Romania, Maramureş county, Muntii Ignis, Deseşti-Stațiunea Izvoare, forest spring at settlement, 920m, N4745.167' E2343.013', 08.X.2010 leg. P. Barcánfalvi, D. Murányi \& J. Oláh, (8 males, OPC). Romania, Caras-Severin county, Semenic Mts. Open brook E of Mt. Piatra Goznei, 1340m, N45 $10.949^{\prime}$ E22 ${ }^{\circ} 03.967 ', 11 . V I .2011$, leg. T. Kovács, D. Murányi \& G. Puskás, (6 males, OPC). Romania, Caras-Severin county, Tarcu Mts. Spring and its outlet at Cuntu Meteorological Station, $1465 \mathrm{~m}, \mathrm{~N}^{\circ} 5^{\circ} 18.008^{\prime}$ E22 ${ }^{\circ}$ 30.059', 9.VI.2011, leg. T. Kovács, D. Murányi \& G. Puskás, (8 male, OPC). Romania, Hargitha Mts., Sincraieni, Valea Mare,, 5. VII.1993, leg. L. Keresztes (4 males, 1 female; OPC). Romania, Muntii Rodnei, Statiunea Borsa, open stream and its sidebrooks, 8781022m, 28.VI.2005, leg. J. Kontschán, D. Murányi \& K. Orci (8 mlaes, HNHM). Romania, Southern Carpathians, Semenic Mts., 28.VII.2006, leg. M. Bálint (31 males, OPC). Slovakia, Roznava, Majerska Dolina, 23.VII.1964 singled leg. J. Oláh \& Z. Varga (6 males, OPC). Slovakia, Tatranská Lomnica, small spring stream, 20.VII.1966, singled leg. J. Oláh (3 males, OPC). Slovakia, Rejdova (Sajóréde), Mlynna stream, below spring, at bridge, N48 $46^{\prime} 16^{\prime \prime}$ E20¹3'31" 1250 m, 3.X.2013, singled leg. J. Oláh \& J. Kecskés J. (38 males, 2 females; OPC). Slovakia Rejdova (Sajóréde), right tributary of Slana (Sajó) stream, lower reach, N48 48'53" E20 ${ }^{\circ} 15^{\prime} 51^{\prime \prime} 680$ m, 3. X.2013, singled leg. J. Oláh \& J. Kecskés J. (41 males, 3 females, OPC). Slovakia, E Slovakia, Vihorlatské hills, Malá Bystrá stream (560-700 m), 4856'16"N, 22¹1'36"E, 9.X.1990, leg. P. Chvojka (24 males, 10 females, NMPC; 6 males, OPC). Slovakia, W Slovakia, Strážovské Mts., Strážovský potok stream (800$1000 \mathrm{~m}), 48^{\circ} 57^{\prime} 41^{\prime \prime N}, 18^{\circ} 28^{\prime} 02^{\prime \prime E}$, 19.IX.2009, leg. P. Chvojka (12 males, 10 females, NMPC; 6 males, OPC). Slovakia, Dobsina, Dankova, 12.X.1989, leg. Á. Uherkovich \& S. Nógrádi (3 males, 1 female, OPC). 


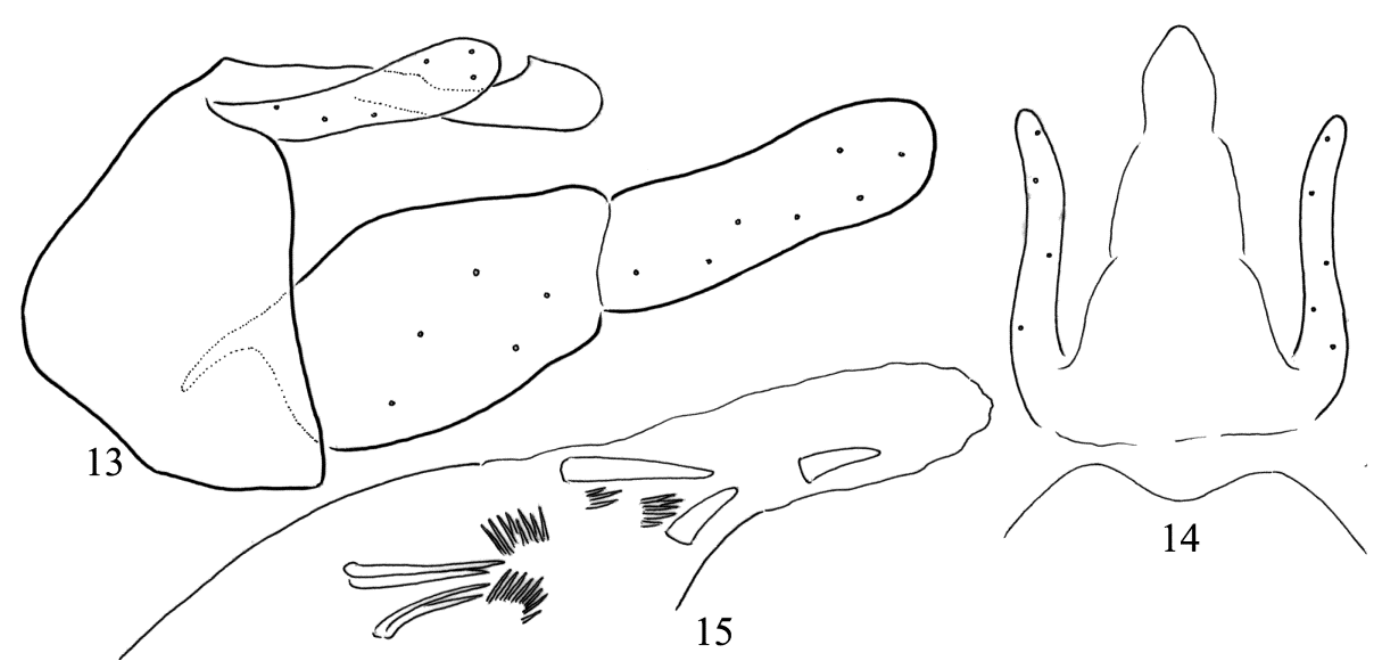

Figures 13-15. Wormaldia carpathica Oláh, sp. nov. Holotype: $13=$ male genitalia in left lateral view, $14=$ mesal excision on tergite VIII and segment X with cerci in dorsal view, 15 = phallic organ with the endothecal spine pattern in left lateral view.

Slovakia, Hrabosice, 26.IX.1984, leg. Á. Uherkovich \& S. Nógrádi (20 males, OPC). Slovakia, Hrabosice, 13.X.1989, leg. Á. Uherkovich \& S. Nógrádi (1 male, 1 female, OPC). Ukraine, Bieszczady Mts (Besszádok), Ung National Park, below Lubnya (Kiesvölgy), N: $49^{\circ} 00^{\prime} 54.81^{\prime \prime}$ E: $22^{\circ} 43^{\prime} 23.82^{\prime \prime}, 478 \mathrm{~m}$, singled, 20. IX.2013, leg. J. Oláh, Cs. Balogh, Cs. Deák \& I. Meszesán (2 females; OPC). Ukraine, Bieszczady Mts (Besszádok), Ung National Park, small forested stream between Uzsok Pass and Uzsok, N: 48 $59^{\prime} 33.52^{\prime}$ E: 22 ${ }^{\circ} 52^{\prime} 03.40 ", 642 \mathrm{~m}$, singled, 20.IX.2013, leg. J. Oláh, Cs. Balogh, Cs. Deák \& I. Meszesán (8 males, 7 females; OPC).

Diagnosis. Having parallel-sided harpago $W$. carpathica sp. nov. belongs to the Wormaldia occipitalis species group and having very complex endothecal spine system belongs to the $W$. occipitalis species cluster. It is most close to $W$. hellenica, but differs by having more elongated apex of segment X; having only a pair, not three basal slender spines and the pair of posterior endothecal spine cluster is highly reduced both in number and length. Moreover, W. carpathica sp. nov. is larger and lighter species.

Distinguishing diagnosis. This species is delineated by the character combination detailed below. Easily identified by the combination of (1) the perfectly horizontal, elongated plum-shaped semicircular apex of segment $X,(2)$ the absence of the fifth specialized spine cluster composed of many and densely packed small black spines, (3) the absence of the third slender basal endothecal spine, and (4) the highly reduced pair of posterior endothecal spine clusters.

Description. Male (in alcohol). Medium-sized ligth brown animal. Sclerites medium brown, setal warts both on head and thorax and legs brown. Maxillary palp formula is I-II-IV-III-V. Forewing length $4 \mathrm{~mm}$. Spur formula is 244 .

Male genitalia. Tergit VIII with shallow and wide mesal excision on the apical margin. Segment $\mathrm{X}$ characterized by triangular apex in dorsal view, and by a dorsal small pointed subapical process visible in lateral view; the ending is armed with sensory structures of sensilla basiconica (pegs) or sensilla coeloconica (pitted pegs) both on the very dorsal ending of the narrowing apex as well as on the sublateral broadening. Cerci slender, slightly clavate with blunt apex. Gonopods very produced, coxopodite and harpago with equal length; harpagones parallel-sided in lateral view. Phallic organ with eversible membranous endotheca containing a pair of slender basal spines each frequently doubled or tripled adhering basad; two pairs of spine clusters composed of small spines; posterior spine cluster reduced; one long and two short stout spines present. 


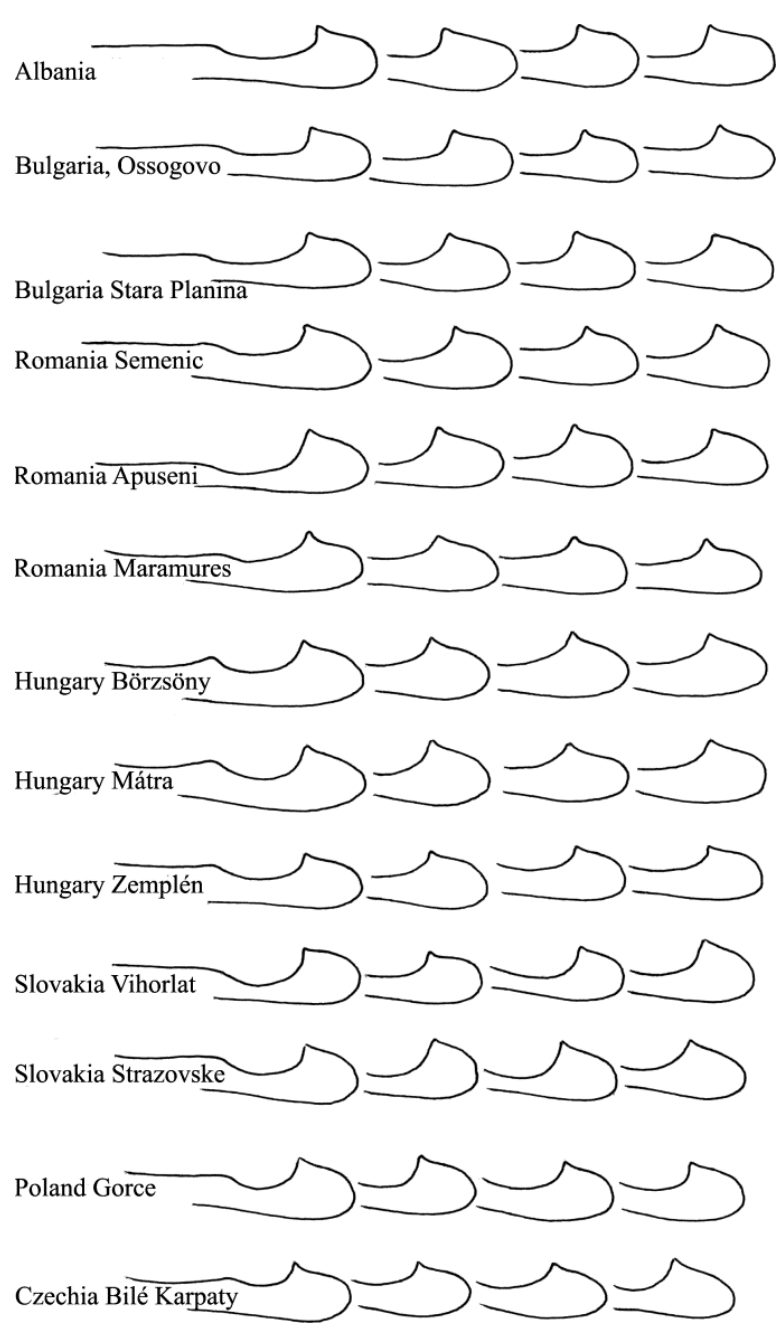

Figures 16-67. Lateral profile of the speciation trait that is the head of segment $\mathrm{X}$ of the paratypes of Wormaldia carpathica Oláh, sp. nov. from various Carpathian regions.

Character combination. (1) Excision on tergite VIII shallow and wide. (2) Dorso-subapical point of segment $X$ tiny, visible in lateral profile as the top point formed by the apical right-angle of the dorsal concavity. (3) Apex of segment X perfectly horizontal and plum-shaped elongated semicircular. (4) Apex of cerci rounded. (5) Ventromesal projection of cerci lacking. (6) Harpagones parallel-sided. (7) Slender and long basal spines organized in a pair each frequently doubled or tripled. (8) Proximal pair of clusters of small spines short. (9) Distal pair of clusters reduced in number and length. (10) Three stout spines present. (11) Specialised fifth cluster of small spines lacking.
Variability. Examining over six hundred specimens we have found only a single male with a triplet of basal slender spine pattern. It was possibly the result of desintegration due to copulation or during the preparation.

Contact zone. We have found mixed populations of $W$. carpathica and $W$. subterranea Northwest of the distributional area in the White Carpathians of Czech Republic and Southwest in Bulgaria with intermediate hybrids having less elongated head of segment $\mathrm{X}$ and/or abbreviated spines of posterior clusters.

Etymology. This new species populates all ranges of the Carpathian Mountains. The specific epithet refers to this distribution.

\section{Wormaldia cianficconiae Neu, 2017}

(Figures 68-70)

Wormaldia cianficconiae Neu, 2017:114, „differentiated from Wormaldia occipitalis Pictet, 1834 and Wormaldia subterranea Radovanovic, 1932 by the combination of the following characters: (1) in lateral view, a distinct hump in the middle of segment $\mathrm{X}$ before the saddle-shaped depression in the distal half, (2) aedeagus without long, needle-like spines, but with a diffuse group of about 25 short spines, two groups of 4-8 long spines and three or four strong thorns."

Material examined. Locus typicus: Italy, LazioRieti, Cittareale, Sorg. Velino loc. Cupello, N42.619 E13.153ㅇ, 980m, 26.VIII.1991, leg. P. Capoccia, det. (2017) P.J. Neu (1 male, 1 female, CNSMB; 1 male, OPC).

\section{Wormaldia hellenica Jacquemart, 1962}

$$
\text { (Figures 71-73) }
$$

Wormaldia hellenica Jacquemart, 1962:3-4, „Materiel. - Récoltés par la mission E. Janssens-R Tollet, Mont Pélion W. Drakia (Khani Zisi) $(1.200 \mathrm{~m})$, 28/30-VII-1953, 5 preparations microscopiques, Mont Alympe E Stavros a Prioni, 1.000 m, 21/23VII-1953, 1 preparation microscopique."'

Wormaldia hellenica Jacquemart, 1962: Malicky 2005:549, Unclear taxonomic position.

Wormaldia hellenica Jacquemart, 1962: Neu 2015:107, Raised to species rank. 


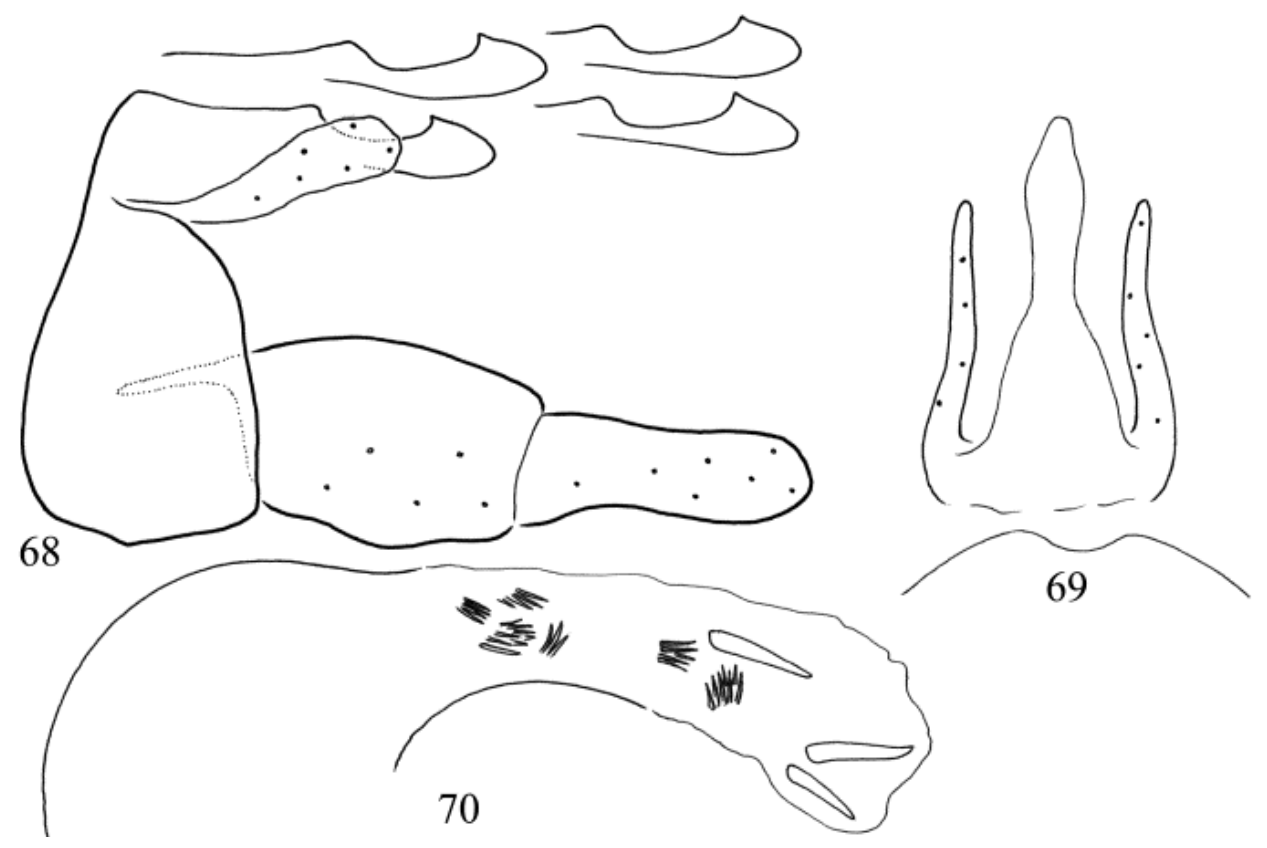

Figures 68-70. Wormaldia cianficconiae Neu, 2017. 68 = male genitalia in left lateral view, $69=$ mesal excision on tergite VIII and segment $\mathrm{X}$ with cerci in dorsal view, 70 = phallic organ with the endothecal spine pattern in left lateral view.

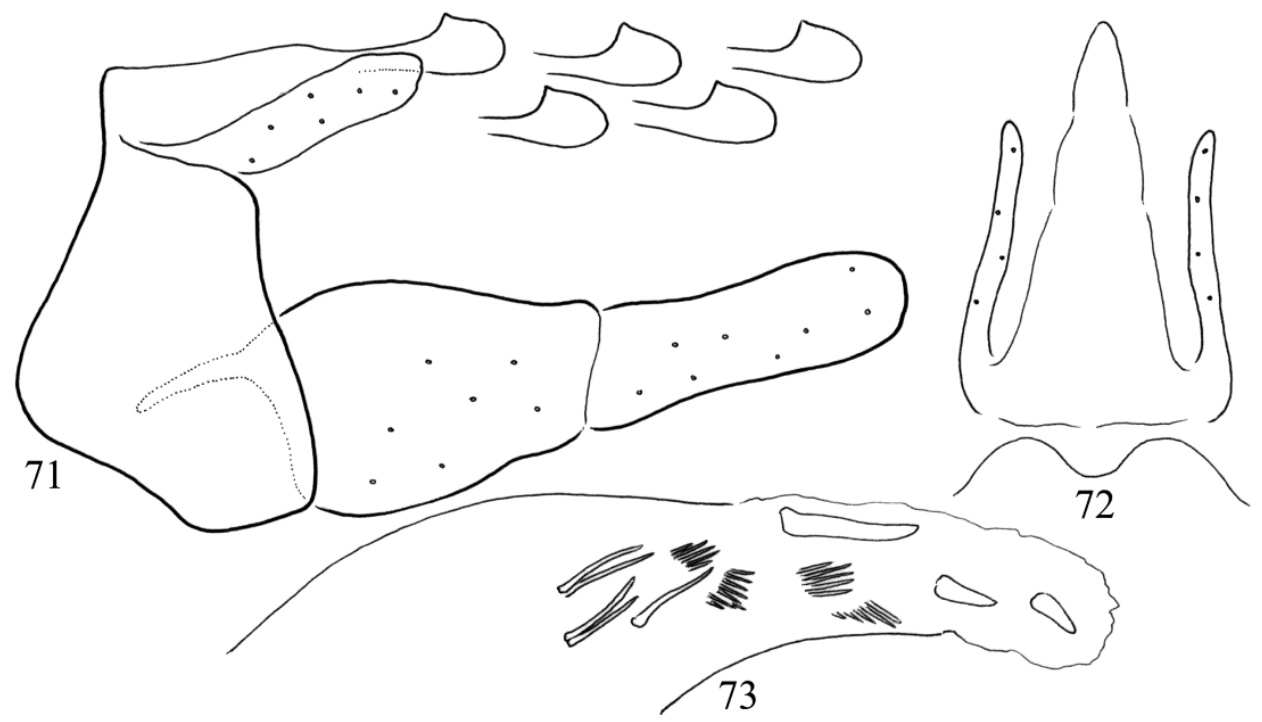

Figures 71-73. Wormaldia hellenica Jacquemart, 1962. 71 = male genitalia in left lateral view, $72=$ mesal excision on tergite VIII and segment $\mathrm{X}$ with cerci in dorsal view, 73 = phallic organ with the endothecal spine pattern in left lateral view.

Material examined. Albania, Malësia e Tiranës (Highlands of Tirana), below Maja e Fekenit (=Feken peak), west from Qafa e Selitës pass, N41 $22^{\prime} 12^{\prime \prime}$, E01959'11", 1100 m, 12.VIII.2018, leg. S. Beshkov A. Nahirnic \& C. Plant (2 males, OPC).
Character combination. (1) Excision on tergite VIII deep and narrow. (2) Dorso-subapical point of segment $\mathrm{X}$ tiny, visible in lateral profile as the top point formed by the apical right-angle of the dorsal concavity. (3) Apex of segment X horizon 
tal almost semicircular. (4) Apex of cerci rounded. (5) Ventromesal projection of cerci almost lacking. (6) Harpagones parallel-sided. (7) Slender and long basal spines organized in a triplet, each could be doubled or tripled. (8) Proximal pair of clusters of small spines short. (9) Distal pair of clusters short. (10) Three stout spines present. (11) Specialised fifth cluster of small spines lacking.

Remarks. The two $W$. hellenica specimens were collected by light from the same habitat in the same evening and preserved in alcohol together with two $W$. carpathica sp. nov. specimens. This identical treatment permits a comparative gross visual examination of the two species. The general colour and the size of the two species are strikingly different as visible without any microscope, simply with naked-eye. Wormaldia hellenica is smaller and dark greyish brown compared to the larger and yellowish brown Wormaldia carpathica sp. nov. specimens. The difference in abdomen and genitalia colours between the greyish brown hellenica and the yellowish brown carpathica remained even more pronounced after clearing in alkaline solution of $\mathrm{NaOH}$ and under the microscope. The colour contrast of the cleared abdomens of the two species is remarkable. However, identically collected, preserved and cleared specimens are seldom available for such a comparative study. We need to apply fine phenomics to distinguish the two sibling species.

\section{Wormaldia juliani Kumanski, 1979}

(Figures 74-76)

Wormaldia juliani Kumanski, 1979:58-60, „Material and localities. Bulgaria, Maleshevska Mt., streamlet falling into Struma River, nearly $2 \mathrm{~km}$ over railway station Kresna (about 400 m a.s.1.), 9.VI.1975, Holotype $\hat{\sigma}$ and 4 Paratypes ( $3 \hat{\partial} \widehat{\partial}$ and 19 ). Strandzha Mts., spring Aidere near the bridge on the road Malko Tarnovo-Zvezdetz, 11.VII.1975, 10 Paratype. Holotype and 4 Paratypes deposed in the author's collection in the National Natural History Museum, Sofia; $1 \sigma^{\lambda}$ Paratype in coll. H. Malicky, Lunz am See, Austria. I am very obliged to Dr.
Malicky for reexamining and confirming the new species."

Wormaldia occipitalis vaillantorum Botosaneanu, 1980a:168-169, „Holotype $\widehat{\partial}$ de l'ile grecque de Kérkira (=Corfou): Or. (=Mt.) Pantokrator, $900 \mathrm{~m}$. alt., Mai („,16/30”) 1971, coll. B. van Aartsen. J'ai trouvé cet exemplaire dans les collections entomologiques de notre Musée; il y est conservé à sec, abdomen dans un petit tube à glycérine."

Wormaldia juliani vaillantorum Botosaneanu, 1980: Botosaneanu 2004:162, Subspecies.

Wormaldia juliani Kumanski, 1979, Wormaldia vaillantorum Botosaneanu, 1980: Malicky 2005:549, Unclear taxonomic position.

Wormaldia juliani Kumanski, 1979: Neu 2015:107, Synonymised Wormaldia occipitalis vaillantorum Botosaneanu, 1980, with Wormaldia juliani $\mathrm{Ku}-$ manski, 1979.

Material examined. Lectotype: Bulgaria, Maleshevska Mt., streamlet falling into Struma River, nearly 2 $\mathrm{km}$ over railway station Kresna (about $400 \mathrm{~m}$ a. s. 1.), 9.VI.1975. leg. K.P. Kumanski (1 male, NMNHS). Allotype: same as lectotype ( 1 female, NMNHS). Macedonia, Southeastern region, Plavuš Hills, Valandovo, forest brook at Motel Izvor, $\mathrm{N}$ of the city, $\mathrm{N} 41^{\circ}$ 19.636', E22 33.327 ', 260 m, 06.05.2014, leg. T. Kovács, D. Murányi (1 male, 2 females; OPC). Macedonia, Southwestern region, Jablanica Mts, Vevčani, Vevčani Springs and outlet stream at the city, N41 ${ }^{\circ} 14.371^{\prime}$, E20³5.056', 935 m, 26.06.2014, leg. P. Juhász, T. Kovács, D. Murányi (1 male, OPC). Serbia, S Serbia, Bujanovac Distr., Starac Mt., Turski Grob near Pcinja River Valley, 821m, N42 $20125^{\prime \prime}$ E $21^{\circ}$ 52'46" 31.V.2018, leg. S. Beshkov, C. Plant, P. Jaksic \& A. Nahirnic (1 male, OPC).

Remarks. No real clusters of small spines, but a number of single and/or twined scattered spines present. Distal margin of tergite VIII straight without any excision. Apices of cerci rounded, not truncate. Harpago parallel-sided as long as coxopodite.

\section{Wormaldia meridionalis Vaillant, 1974 stat. nov.}

Wormaldia occipitalis meridionalis Vaillant, 1974:980, „Un seul exemplaire examiné. Petite source se déversant dans la Vésubie, au-dessus de Notre-Damede-Fenestre (Var), 1950 m, 30.VIII.1968." Raised hereby to species rank. 


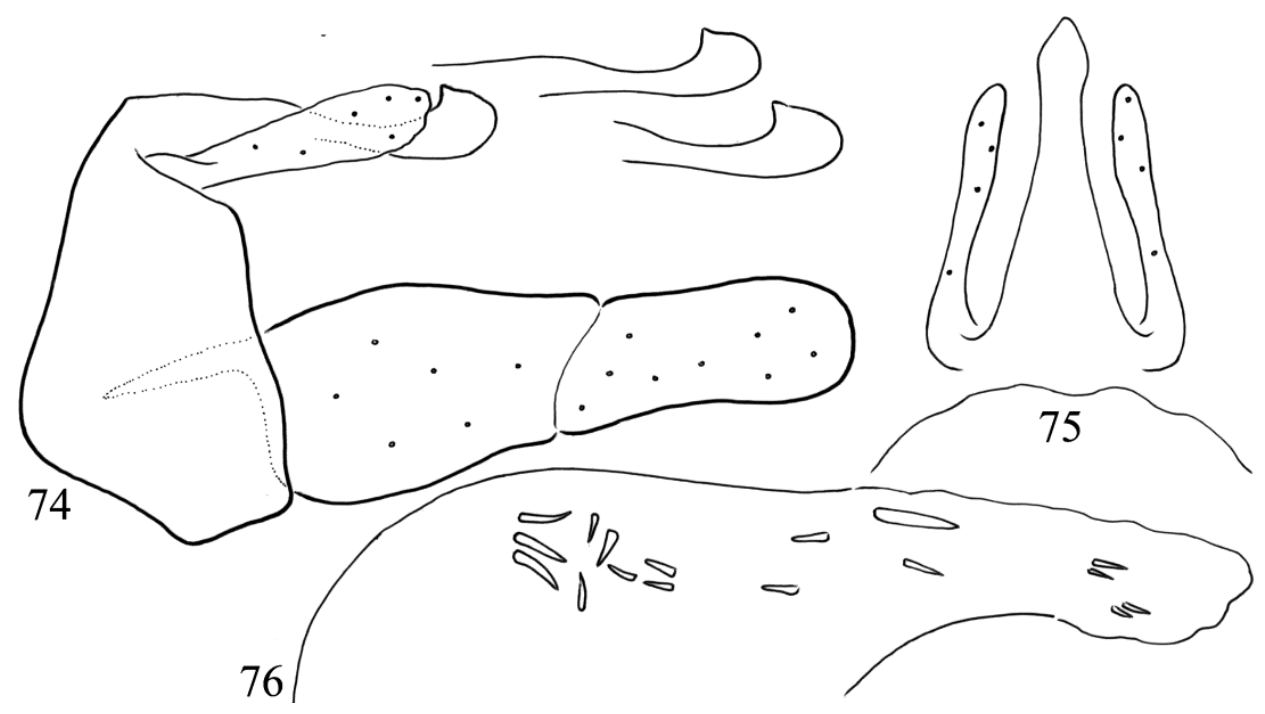

Figures 74-76. Wormaldia juliani Kumanski, 1979. $74=$ male genitalia in left lateral view, $75=$ mesal excision on tergite VIII and segment $\mathrm{X}$ with cerci in dorsal view, 76=phallic organ with the endothecal spine pattern in left lateral view.

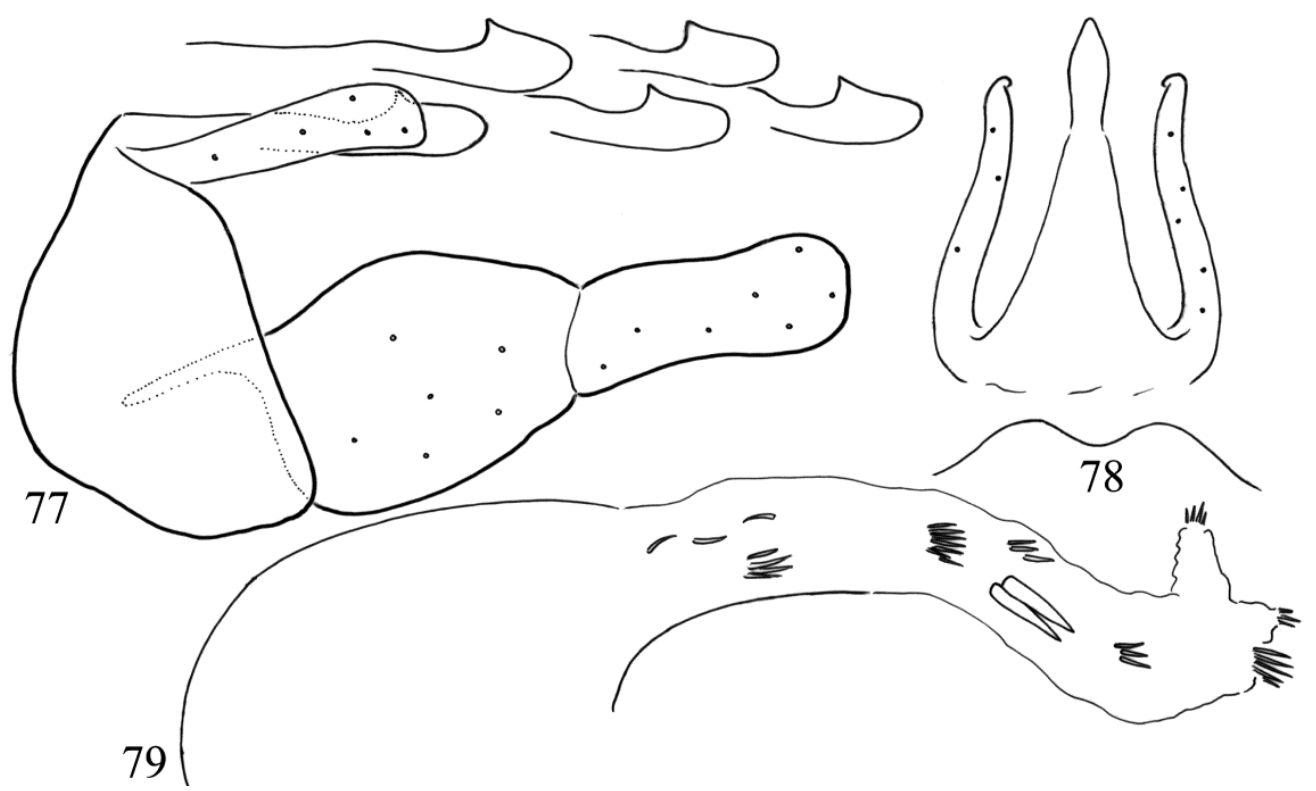

Figures 77-79. Wormaldia morettii Vigano, 1974. 77 = male genitalia in left lateral view, $78=$ mesal excision on tergite VIII and segment $X$ with cerci in dorsal view, 79 = phallic organ with the endothecal spine pattern in left lateral view.

Material examined. Italy, Piemonte-Torino, Ex-

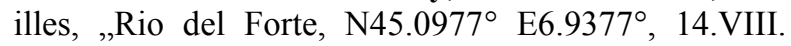
2000, leg. G. B. Delmastro, det. H. Malicky (2001) as W. occipitalis, det. P. J. Neu $(02 / 2016)$ as $W$. occipitalis meridionalis ( 4 males, 4 females, CNSMB; 2 males, OPC).

\section{Wormaldia morettii Vigano, 1974}

(Figures 77-79)

Material examined. Italy, Toscana, Marradi, Monte Bruno, $44.0259^{\circ} \mathrm{N} 11.6786^{\circ} \mathrm{E}, 700 \mathrm{~m}, 9 . \mathrm{VI} .2002$, leg. A. Usvelli, det. P. Neu (2 males, 2 females; CNSMB). 
Italy, Toscana, Pistola dintorni Collina, $44.03^{\circ} \mathrm{N}$ $10.94^{\circ} \mathrm{E}, 17 . \mathrm{VIII} .1966$, leg. A. Vigano, det. M. Valle as $W$. occipitalis (4 males, 6 females, CNSMB; 2 males, 2 females, OPC).

\section{Wormaldia occipitalis (Pictet, 1934)}

\section{(Figures 80-82)}

Material examined. Austria, Tyrol, Galtür, 1600m, 19.IX.1987, leg. G. Uherkovich (1 male, OPC). Czech Republic, N Bohemia, Jizerské hory Mts., tributary of Ješkrabec stream below Český Šumburk, 5043'53"N, 15²0'20"E, 29.IX.2006, leg. P. Chvojka (4 males, 7 females, NMPC; 4 males, OPC). Czech Republic, Central Bohemia, Vůznice Reserve, spring area NE Dřevíč, $50^{\circ} 01^{\prime} 27^{\prime \prime N}, 13^{\circ} 59^{\prime} 09^{\prime \prime E}, 14.6 .-15.9 .2006$, leg. P. Chvojka (3 males, OPC). Czech Republic, E Bohemia, Železné hory Mts., Polom Reserve, springs E Malá Stř́itež, 4947'38"N, 1545'02"E, 29.VI.1999, leg. P. Chvojka (4 males, NMPC; 4 males, OPC). Czech Republic, S Bohemia, Šumava Mts., outlet of Černé lake, 49¹0'55"N, 1311'14"E, 29.9.2010, leg. J. Bojková (2 males, NMPC; 2 male, OPC). England, Cumbria, NW of Kendal, Rather Heath, woodland stream, 24.VIII. 1978, leg. A. Brindle, SD485963, F3298.2309 (2 male, 2 females, MMUE; 3 males, OPC). England, Lancashire, Whalley, Spring Wood, 26.VIII.1974, leg. A. Brindle 34/742363, F3298.2308 (8 males, MMUE; 3 males OPC). England, Lancashire, Higher Hodder Bridge, 15.VII.1979, leg. A. Brindle, SD696412, F3298.2307 (3 males, 1 female, MMUE; 3 males, OPC). England, Yorkshire, Ilkey, Stubham Wood, SE(44)/119488, 24.VI.1977, leg. A. Brindle (4 males, MMUE). France, Pyrenees Mts. Atlantic Pyrenees, Nivelle River System, 12-18.VII.1986, singled leg. J. Oláh (2 males, OPC). France, Alpes-Maritimes, Saorge, torrent Merim résurgence, 3.VII.2016, leg. G. Coppa (1 male, OPC). France, Alpes-Maritimes, Saorge, ru Mairise rive gauche du Cairos, 3.VII.2016, leg. G. Coppa (1 male, OPC). France, Alpes-Maritimes, Entraunes, pra bourres tuf rive droite du Var, 24.VIII.2017, leg. G. Coppa (1 male, OPC). France, Haute-Savoie, Naves Parmelan, zone humide des Caves, 2.IV.2010, leg. G. Coppa (2 males, OPC). France, Herault, Mons, gorges d'Héric suintement rocheux partie en aval, 11.VII.2008, leg. G. Coppa (1 male, OPC). France, Cher, Villegenon, la Nère pont D926, 26.IV.2011, leg. G. Coppa (1 male, OPC). France, Aude, Greffeil, ru de Castillon aval ru de Lauquet greffeil amont, 1.V.2012, leg. G. Coppa (1 male, OPC). France, Aude, Clermont-sur-Lauquet, le Guinet route de Limoux, 2.V.2012, leg. G. Coppa (2 males, OPC). France, Indre, Sainte-Gemmes, fossé près de l'étang Vieux, sortie moine, 28.V.2011, leg. G. Coppa (1 male, OPC). France, Landes, Onesse-et-Laharie, ru d'Hossegen, 9.III.2011, leg. G. Coppa (3 males, OPC). France, Finistère, Camaret, ru Veraych'h, 1.V.2007, leg. G. Coppa (3 males, OPC). Germany, Reinland Pfalz, 54319 Mertesdorf, Quelle NE Dömäne Avelsbach, N49.75610 E6.70460, 17.IV.2011, leg. det. P. J. Neu (2 males, OPC). Germany, Saarland, Waldrill, Goth-Bach, NW Waldrill, N49.58948 E6.88400, 17.V. 2015, leg. det. P.J. Neu (3 males, OPC). Germany, Damshausen, Qeullbach am Bauerst, Ohe-Quellgebiet, N50.83340 E8.61671, 16.IX.2015, leg. J. Fischer, det. P. J. Neu (3 males, OPC). Italy, Lombardia, Solto Collina, Valle del Ferro, 500m, 9.VII.2007, leg. M. Bálint, O. Lodovici \& M. Valle (7 males, 6 females, OPC). Italy, Bergamo Province, S. Giovanni Bianco, Roncaglia, hygropetric habitat, $500 \mathrm{~m}$ a.s.l. 4.VIII. 2010, singled leg. O. Lodovici \& J. Oláh (1 male, OPC). Bergamo Province, Lenna, Sorgente Fregera, $500 \mathrm{~m}$ a.s.1. 4.VIII.2010, singled leg. O. Lodovici \& J. Oláh ( 2 males, 2 females, OPC). Norway, Hordaland, Kvinnherad, Rosendal, Vedavika, $60.005103^{\circ} \mathrm{N}$ $5.987725^{\circ} \mathrm{E}, 2 \mathrm{~m}$, outlet of small shallow stream in area with alder forest, bedrock gneiss, 8.IX.1983, sweepnet, leg. T. Andersen (1 male, ZMBN). Sweden, Halland, Halmstad kommun, Fylleån at Anderstorp, $1.3 \mathrm{~km}$ (air) ESE Skedala, 55.6915 ${ }^{\circ} \mathrm{N} 12.9967^{\circ} \mathrm{E}$, 26.VIII.2016, net leg. K.A. Johanson (1 male, SMNH: C409, NHRS-TOBI 000003831).

Character combination. (1) Excision on tergite VIII very shallow and wide. (2) Dorso-subapical point of segment $\mathrm{X}$ pronounced, very protrusive visible in lateral profile as a triangular process. (3) Apex of segment $\mathrm{X}$ characterized by a downward sloping oblique dorsum. (4) Apex of cerci truncate. (5) Ventromesal projection of cerci produced. (6) Harpagones parallel-sided. (7) Slender and long basal spines organized in a pair. (8) Proximal pair of clusters of small spines short. (9) Distal pair of clusters of small spines short. (10) Three stout spines present. (11) Specialised fifth cluster of small spines present.

Variability. Examining specimens from over the entire distribution range we have found rather stable lateral profiles of the head of segment X. Its downward sloping oblique dorsum seems very stable as a speciation trait. 


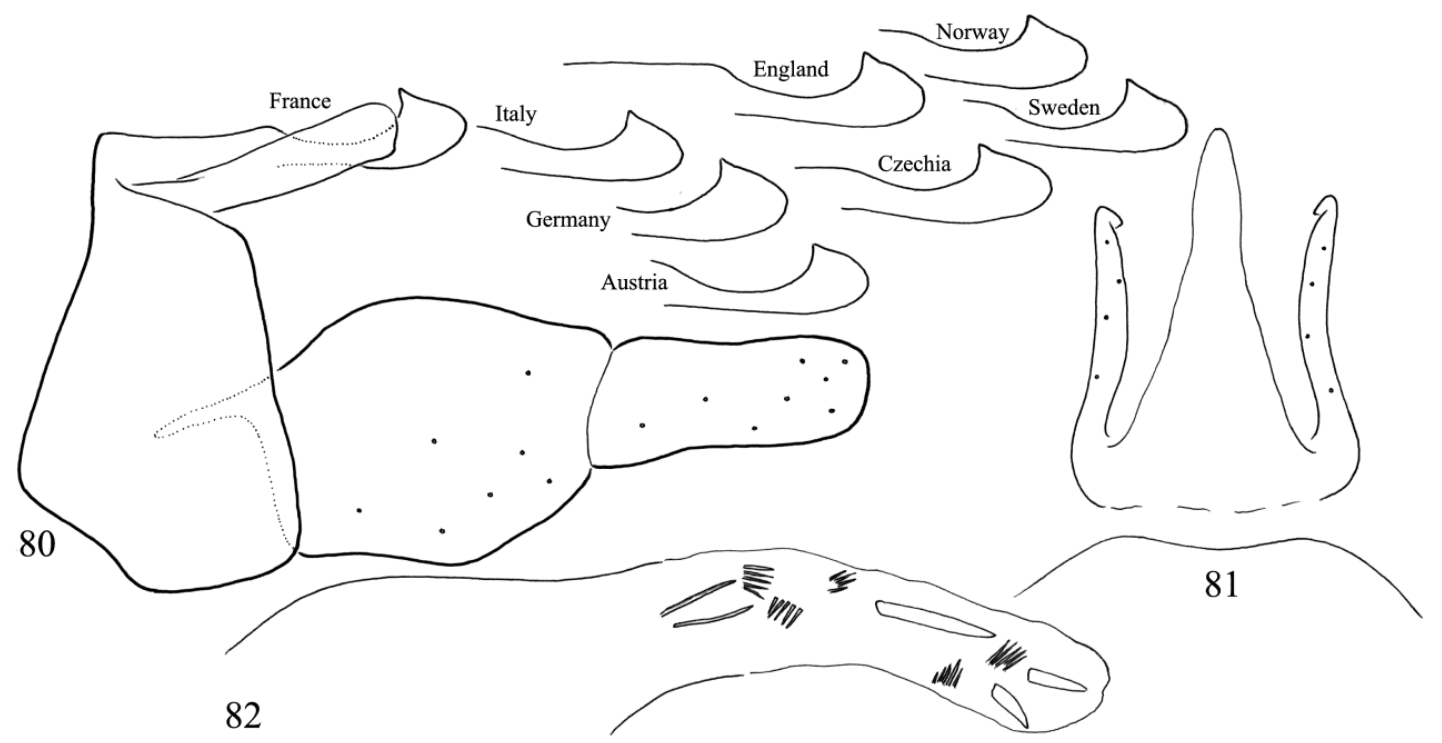

Figures 80-82. Wormaldia occipitalis (Pictet, 1934). $80=$ male genitalia in left lateral view, with lateral profile of the speciation trait that is the head of segment $\mathrm{X}$ from various populations. $81=$ mesal excision on tergite VIII and segment $\mathrm{X}$ with cerci in dorsal view, $82=$ phallic organ with the endothecal spine pattern in left lateral view.

\section{Wormaldia subterranea Radovanovic, 1932}

\section{(Figures 83-85)}

Wormaldia subterranea Radovanovic, 1932:104, "Appendices praeanales einfach; sie erstrecken sich nach hinten beiderseits des umgewandelten 10. Abdominalsegmentes; Genitalfüße zweigliedrig, Glieder ungefähr gleich lang."

Wormaldia occipitalis subterranea Radovanovic, 1932: Kimmins 1953, reduced to subspecies rank.

Wormaldia subterranea Radovanovic, 1938: Botosaneanu 1989:165-166, $W$. subterranea and $W$. occipitalis subterranea were synonymized with $W$. occipitalis occipitalis.

Wormaldia subterranea Radovanovic, 1932: Neu 2015:107, species rank resurrected.

Wormaldia khourmai bulgarica Novák, 1971:105-106 (part.), "Paratypen: Fundorte: Rila-Gebirge; Zufluss des Malovice Flusses, Rilski Monastir, 14.VII. 1962, 50 , 3ㅇ." One paratype from this series has been found in the Kumanski's collection (NMNHS) was misidentified and identified here as Wormaldia subterranea Radovanovic. Misidentification!

Material examined. Austria, Carinthia, Karawanken Mts, Vellach Stream, 25.VII.1989, singled leg. J. Oláh (1 male, OPC). Bosnia-Herzegovina, small right tributary of Neretva River before Mostar, 14.IX.1989, singled leg. J. Oláh mixed population with $W$. bosniaca
(3 males, OPC). Bulgaria: misidenfied paratype of Wormaldia khourmai bulgarica Novák: Rila Mts. tributary of Malovice River, at Rila Monastery, 14.VII.1962, leg. K. Novák, probable hybrid with $W$. carpathica (1 male, NMNHS). Bulgaria, without collecting data, with number 870 of the lost catalogue, found in Kumanski's collection as Wormaldia occiptalis occipitalis (1 male, 2 females, NMNHS). Czech Republic, Central Bohemia, Vůznice Reserve, spring area NE Dřevíč, $50^{\circ} 01^{\prime 2} 27^{\prime \prime N}, 13^{\circ} 59^{\prime} 09^{\prime \prime} \mathrm{E}, 14.6$ 15.9.2006, leg. P. Chvojka (1 male, OPC). N Bohemia, spring area, Růžovský hill NW Srbská Kamenice, $50^{\circ} 49^{\prime} 52^{\prime \prime N}$ 14²0'27"E, 10.VI.-30.VIII.2010, leg. M.Trýzna, (5 males, 14 females, NMPC; 4 males, OPC). Germany, Saarland, Bethingen, Waldbach zum Salzbach, $1 \mathrm{~km}$ E Bethingen, N49.46170 E6.55039, 260m, 16.VI.2013, leg. det. P.J. Neu (1 male, 1 female; OPC). Reinland Pfalz, 55774 Baumholder, Nebenbach an der L $169 c a .3 .5 \mathrm{~km}$ SE Baum, N49.60724 E7.38919, 320 m, 13.VI.2009, leg. det. P. J. Neu (1 male, 1 female; OPC). Hungary, Mecsek Mts. Pécs, Bodóhegy, 11.VI.1938, leg. J. Sátori, determined by Sátori as Wormaldia triangulifera (1 male, 1 female; OPC). Mecsek Mts., Magyaregregyi Vár Valley, N46 ${ }^{\circ}$ 13.0956' E $18^{\circ} 21.5538^{\prime}, 466$ m, Pásztor spring, 2.VI. 1988, singled leg. J. Oláh (5 males, 5 females; OPC). Mecsek Mts., Vékény, Várvölgy, 4.VI.1984, leg. S. Nógrádi, (3 males, OPC). Mecsek Mts., Kisújbánya, Pásztor-forrás, 3.IX.1984, leg. S. Nógrádi, (3 males, 2 females; OPC). Köszeg Mts., Stájer Házak, 18.X.1986, leg. Á. Uherkovich (9 males, OPC). Köszeg Mts., 


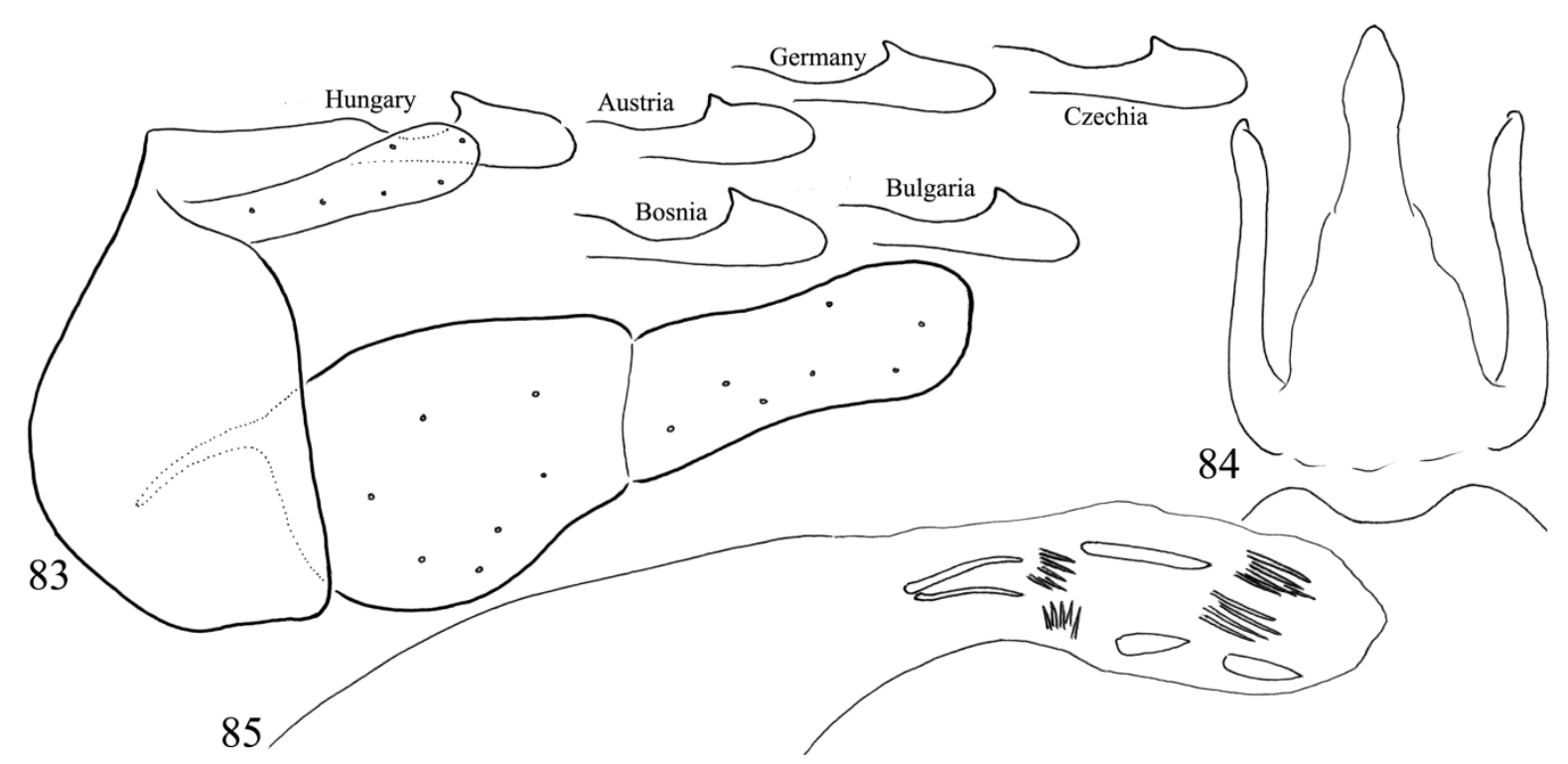

Figures 83-85. Wormaldia subterranea Radovanovic, 1932. 83 = male genitalia in left lateral view, with lateral profile of the speciation trait that is the head of segment $\mathrm{X}$ from various populations. $84=$ mesal excision on tergite VIII and segment $\mathrm{X}$ with cerci in dorsal view, $85=$ phallic organ with the endothecal spine pattern in left lateral view.

Stájer Házak, 5.X.1991, leg. Á. Uherkovich (3 males, 1 female; OPC). Köszeg Mts., Hármas-patak, 5.X. 1991, leg. Á. Uherkovich (1 male, 2 females; OPC). Szöce, spring at the Research Station, 18.VI. 1984, leg. G. Uherkovics \& S. Nógrádi (17 males, OPC). Kám, Jeli Arborétum, 24.V.1984, leg. G. Uherkovics \& S. Nógrádi (11 males, 2 females; OPC). Montenegro, Kolasin area, Ibristica stream, 8.V. 2007, leg. V. Pesik (1 male HNHM). Sinjajevina Mts. Gornji Lipovo NW 4km, beech forest and forest brook, $1351 \mathrm{~m}, \mathrm{~N} 42^{\circ} 53.829^{\prime}$ E19²3.140', 11.X.2008, leg. L. Dányi, Z. Fehér, J. Kontschán \& D. Murányi (2 males, HNHM).

Character combination. (1) Excision on tergite VIII medium shallow and wide. (2) Dorsosubapical point of segment $\mathrm{X}$ most pronounced in the occipitalis complex (Kimmins 1953, Botosaneanu 1989), very protrusive visible in lateral profile as turning anterad. (3) Apex of segment X horizontal and very elongated ovoid. (4) Apex of cerci rounded. (5) Ventromesal projection of cerci slightly produced. (6) Harpagones parallel-sided. (7) Slender and long basal spines organized in a pair each could be doubled or tripled. (8) Proximal pair of clusters of small spines short. (9) Distal pair of clusters elongated. (10) Three stout spines present. (11) Specialised fifth cluster of small spines lacking.
Contact zone. We have found mixed populations of $W$. subterranea and $W$. carpathica northwest of the distributional area in the White Carpathians of Czech Republic and Southwest in Bulgaria with intermediate hybrids having less elongated head of segment $\mathrm{X}$ and/or abbreviated spines of posterior clusters. In Bosnia-Herzegovina along the Neretva Valley we have found mixed population of $W$. subterranea and $W$. bosniaca with intermediate hybrids having shortening head of segment $X$ and without the fifth characteristic dense cluster composed of many thin spines.

Wormaldia trifida Andersen, 1983 stat. nov.

$$
\text { (Figures 86-88) }
$$

Wormaldia occipitalis trifida Andersen, 1983:202_204.

Wormaldia occipitalis trifida Andersen, 1983: Malicky 2005:549, unclear taxonomic position.

Wormaldia occipitalis trifida Andersen, 1983: Neu 2015: 110, synonymised with Wormaldia occipitalis occipitalis.

Material examined. Holotype: Norway, inner Hordaland, Ullensvang, Hovland (UTM: 32VLM 
684803), 14-30. IX. 1977, leg. T. Andersen In coll. Zool. Mus. Bergen, mounted on four slides (no. A 11805 a-d). Telemark, Porsgrunn, Hitterbekk, $59.073897^{\circ} \mathrm{N} 9.650094^{\circ} \mathrm{E}, 27 \mathrm{~m}, 20.07 .1988$, sweepnet, leg. G.E.E. Søli (23 males, 1 female, ZMBN). Telemark, Porsgrunn, Hitterbekk, $59.073897^{\circ} \mathrm{N}$ $9.650094^{\circ} \mathrm{E}, 27 \mathrm{~m}$, small, fast flowing stream in limestone area with bottom substrate stones and gravel, 15.VII-19.X.1988, Malaise trap, leg. G.E.E. Søli (33 males, 188 females, ZMBN). Hordaland, Tysnes, Ånuglo, $59.923709^{\circ} \mathrm{N} 5.730776^{\circ} \mathrm{E}, 5 \mathrm{~m}$, small seep over limestone bedrock, 7.VI.1990, sweepnet, leg.T. Andersen (12 males, ZMBN). Hordaland, Ullensvang, Hovland, $60.236179^{\circ} \mathrm{N} 6.619910^{\circ} \mathrm{E}, 20 \mathrm{~m}$, small shallow stream in area with farmland, bedrock gneiss, 1430.IX.1977, light trap, leg. T. Andersen (1 male, ZMBN). Sweden, Skåne, Vitbäckskällan, $55.5888^{\circ} \mathrm{N}$, $13.7854^{\circ} \mathrm{E}$, spring stream with mix of coarse and fine sand, 30.VI.2016, net leg. K. A. Johanson (2 males, SMNH: C219, NHRS-TOBI 000003742; C257, NHRS-TOBI 000003829). Östergötland län, Ödeshögs kommun, Omberget, stream, $58.3165^{\circ} \mathrm{N}, 14.6282^{\circ} \mathrm{E}$, 1.VII.2016, net leg. K. A. Johanson (1 male, SMNH: C512, NHRS-TOBI 000003830). Skåne, Båstad commune, Lyadalen Nature Reserve, stream, $56.4126^{\circ} \mathrm{N}$ $12.8611^{\circ} \mathrm{E}$, 1.VII.2017, net leg. K.A. Johanson (1 male, SMNH: C082, NHRS-TOBI 000003832). Skåne, Ångelholms commun, $\mathrm{N}$ shore of Lake Västersjön, $56.3272^{\circ} \mathrm{N}, 13.0430^{\circ} \mathrm{E}, 24 . \mathrm{VI} .2015$, net leg. K.A.
Johanson (1 male, SMNH: B467, NHRS-TOBI 000003828).

Character combination. (1) Excision on tergite VIII shallow and wide. (2) Dorso-subapical point of segment $\mathrm{X}$ pronounced, less protrusive visible in lateral profile as a small triangular process. (3) Apex of segment $\mathrm{X}$ characterized by semicircular configuration. (4) Apex of cerci truncate. (5) Ventromesal projection of cerci produced. (6) Harpagones parallel-sided. (7) Slender and long basal spines organized in a pair. (8) Proximal pair of clusters of small spines short. (9) Distal pair of clusters of small spines short. (10) Three stout spines present. (11) Specialised fifth cluster of small spines indistinct.

Remarks. This species is distinguished from its sibling species, Wormaldia occipitalis clearly by the speciation trait of the head of segment $X$. Apex of segment $X$ characterized by a downward sloping oblique dorsum at $W$. occipitalis, but characterized by semicircular configuration at $W$. trifida. Divergence seems subtle, but stable. Here we reinstate its taxon status and elevate it to species rank; stat. nov.

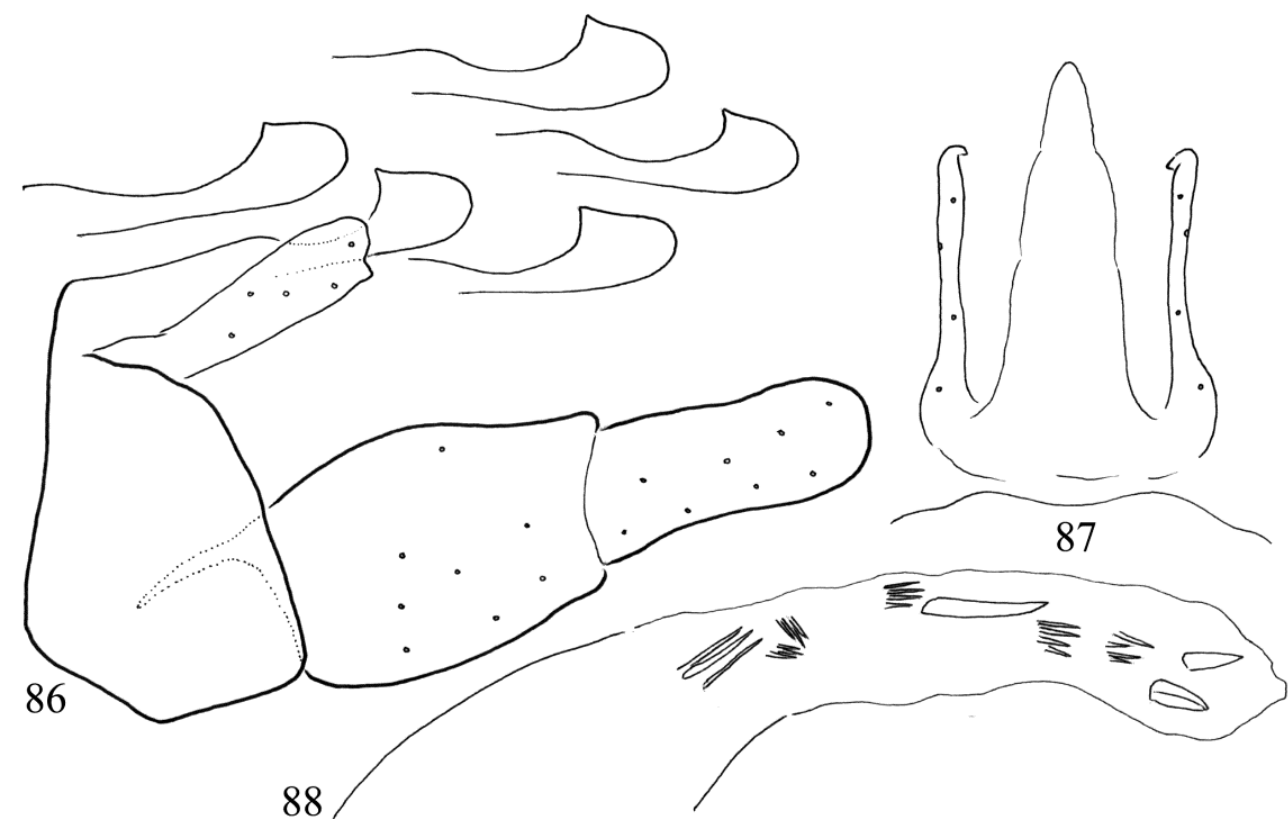

Figures 86-88. Wormaldia trifida Andersen, 1983. 86 = male genitalia in left lateral view, with lateral profile of the speciation trait that is the head of segment $\mathrm{X}$ from various populations of Norway and Sweden. 87 = mesal excision on tergite VIII and segment $\mathrm{X}$ with cerci in dorsal view, 88 = phallic organ with the endothecal spine pattern in left lateral view. 


\section{Wormaldia charalambi species group}

This species group is characterized by the combination (1) of the parallel-sided, not tapering harpago with pointed head, (2) the terminal of segment X with capitate "head" and with dorsal subapical pointed process and (3) the endothecal spine pattern without clusters of small spines and with 3-4 variously shaped and sized spines.

\section{Wormaldia kurta Oláh, sp. nov.}

(Figures 89-91)

Wormaldia charalambi Malicky, 1980: Oláh \& Kovács 2014:99, a single male and six associated females from Greece, Rhodope peripheral unit, Sapka Mts. Misidentification!

Wormaldia charalambi Malicky, 1980: Oláh \& Beshkov 2016:88, a single male from Bulgaria, Pirin Mts. Misidentification!

Material examined. Holotype: Bulgaria, S. Pirin, Alibotush Mts., Gradishte between Nova Lovcha and Paril villages, $750 \mathrm{~m}, \mathrm{~N} 41^{\circ} 26^{\prime} 00^{\prime \prime} \mathrm{E} 23^{\circ} 41^{\prime} 52^{\prime \prime}, 23$.VI. 2014, leg. S. Beshkov \& M. Beshkova (1male, OPC). Pratypes: Greece, Thrace, Rhodope peripheral unit, Sapka Mts., Kizario, stream and pasture SW of the village, $140 \mathrm{~m}, \mathrm{~N} 41^{\circ} 03.492^{\prime} \mathrm{E} 25^{\circ} 45.672^{\prime}$, 27.V.2012, leg. J. Kontschán, D. Murányi, \& T. Sederjesi (1 male, OPC). Thrace, Rhodope peripheral unit, Sapka Mts., Nea Sanda, open brook and pasture NE of the village, 790 m, N4107.965' E2554.052', 26.V.2012, leg. J. Kontschán, D. Murányi, \& T. Szederjesi (6 associated females, OPC).
Diagnosis. Having harpago with pointed apex W. kurta sp. nov. belongs to the Wormaldia charalambi species group and is most close to $W$. yavuzi Sipahiler, 1996 described from the middle of South Turkey. But it differs by having very short, abbreviated coxopodite of gonopod, not long; tergite VIII with smooth flat apical margin without any setae in dorsal view, not with two mesal humps armed with bunch of sensory setae; the endothecal spine is stout, not slim slender.

Description. Male (in alcohol). Small castanean brown animal. Sclerites medium brown, setal warts both on head and thorax and legs brown. Maxillary palp formula is I-II-IV-III-V. Forewing length $4 \mathrm{~mm}$. Spur formula is 244 .

Male genitalia. Tergite VIII smooth plane without any discernible mesal excision on the apical margin. Segment $X$ characterized by triangular apex in dorsal view, and by a dorsal small pointed subapical process visible in lateral view; the ending is armed with sensory structures of sensilla basiconica (pegs) or sensilla coeloconica (pitted pegs) both on the very dorsal ending of the narrowing apex as well as on the sublateral broadening. Cerci with blunt apex. Gonopods, both coxopodite and harpago short and high (broad); harpagones with pointed apex as visible in lateral view. Phallic organ with eversible membranous endotheca containing a single long spine as stout as the short two stout spines; short spines are with enlarged rounded basement and slightly arching body.

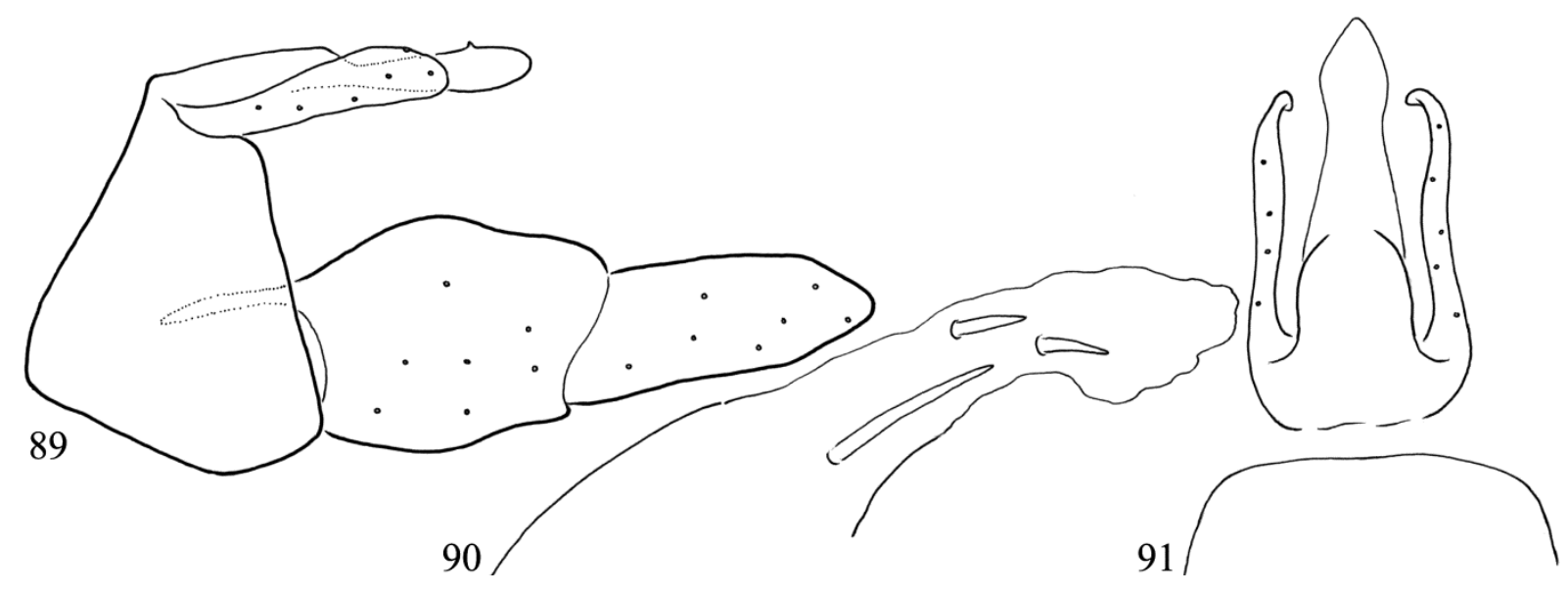

Figures 89-91. Wormaldia kurta Oláh sp. nov. Holotype: $89=$ male genitalia in left lateral view, $90=$ mesal excision on tergite VIII and segment $\mathrm{X}$ with cerci in dorsal view, 91=phallic organ with the endothecal spine pattern in left lateral view. 
Etymology. kurta, from "kurta", short, curt, cutty in Hungarian, refers to the abbreviated coxopodite of the gonopod.

\section{Wormaldia copiosa species group}

This species group is characterized by the combination (1) of the abbreviated parallel-sided, not tapering harpago, (2) the terminal of segment $\mathrm{X}$ without formal capitate "head" that is the ending of segment $\mathrm{X}$ is not forming an enlarged rounded variously shaped apical head and (3) the endothecal spine pattern without clusters of small spines and with 3-4 variously shaped and sized spines in various numbers.

\section{Wormaldia botosaneanui Moretti, 1981}

(Figures 92-94)

Wormaldia copiosa botosaneanui Moretti, 1981:172173: „Wide-based superior appendages which tape abruptly after the outer medial angle. In W. copiosa copiosa these appendages are cylindrical-conical and do not form a medial angle. The phallus endotheca has a comb of a dozen short spines. In $W$. copiosa copiosa the proximal spines are longer, more supple and closer packed than the apical ones."

Material examined. Italy, Toscana-Lucca, Minucciano Pesciola, torrente, affluente destro torrente Acquabianca, in bosco, N44.141429 ${ }^{\circ} \mathrm{E} 10.254128^{\circ}, 680 \mathrm{~m}$, 28.VI.2011, light trap, leg. O. Lodovico, P. Pantini \& M. Valle (2 males, 7 females, CNSMB; 1 male, OPC).

\section{Wormaldia copiosa (McLachlan, 1868)}

(Figures 95-97)

Material examined. Austria, Lienz an der Drau, Tristachersee, 16.VI.1938, leg. J. Sátori (1 male, OPC). Italy, Lombardia-Beergamo, Villa d'Almè, affluente torrente Giongo, N45.7644 ${ }^{\circ}$ E9.6364 ${ }^{\circ}, 400 \mathrm{~m}, 23$.VII.1 998, light trap, leg. E. Ferrario \& P. Pantini (3 males, 1 female, CNSMB; 1 male, OPC).

\section{Wormaldia kakopetros Malicky, 1972}

(Figures 98-100)

Material examined. Paratype: Greece, Crete, Kakopetros, 3.V.1971, leg. H. Malicky (1 male, NMNHS).

\section{Wormaldia marlieri Moretti, 1981}

(Figures 101-103)

Wormaldia pulla marlieri Moretti, 1981:174, „Widebased cerci with squat apical upturned hook, which is absent in $W$. pulla pulla (a). Phallus endotheca terminates in a large curved spine and a fine dorsal sclerite."

Material examined. France, Alpes-Maritimes, Saorge, Bendola au pont de Baoussoun, 7.VII.2016, leg. G. Coppa (2 males, OPC).

\section{Wormaldia parba Oláh, sp. nov.}

(Figures 104-106)

Material examined. Holotype: Albania, Elbasan County, Librazhd municipality, forest brook SW of Fushë Studë 1030m, N41²17.453' E20²2.103' leg. P. Juhász, T. Kovács, D. Murányi, 30.VI.2018 (1 male, OPC).

Diagnosis. This new species belongs to the Wormaldia copiosa species group with short and high harpagones. Wormaldia parba sp. nov. is most close to $W$. kakopetros, but differs by having tergite VIII without mesal excision, harpagones without middle constriction; the dorsal triangular hump is very pronounced; apex of cerci are blunt, not pointed; there are only two equally shaped large spine present in the endotheca, not one long and two small spines.

Description. Male (in alcohol). Small castanean brown animal. Sclerites medium brown, setal warts both on head and thorax and legs brown. Maxillary palp formula is I-II-IV-III-V. Forewing length $4 \mathrm{~mm}$. Spur formula is 244 .

Male genitalia. Tergite VIII smooth flat without rounded triangular mesal excision on the apical margin. Segment $X$ characterized by narrowing apex in dorsal view, and by a middle dorsal pronounced triangular hump visible in lateral view; the ending is armed with sensory structures of sensilla basiconica (pegs) or sensilla coeloconica (pitted pegs) both on the very dorsal ending of the narrowing apex as well as on the sublateral broadening. Cerci with blunt apex. 


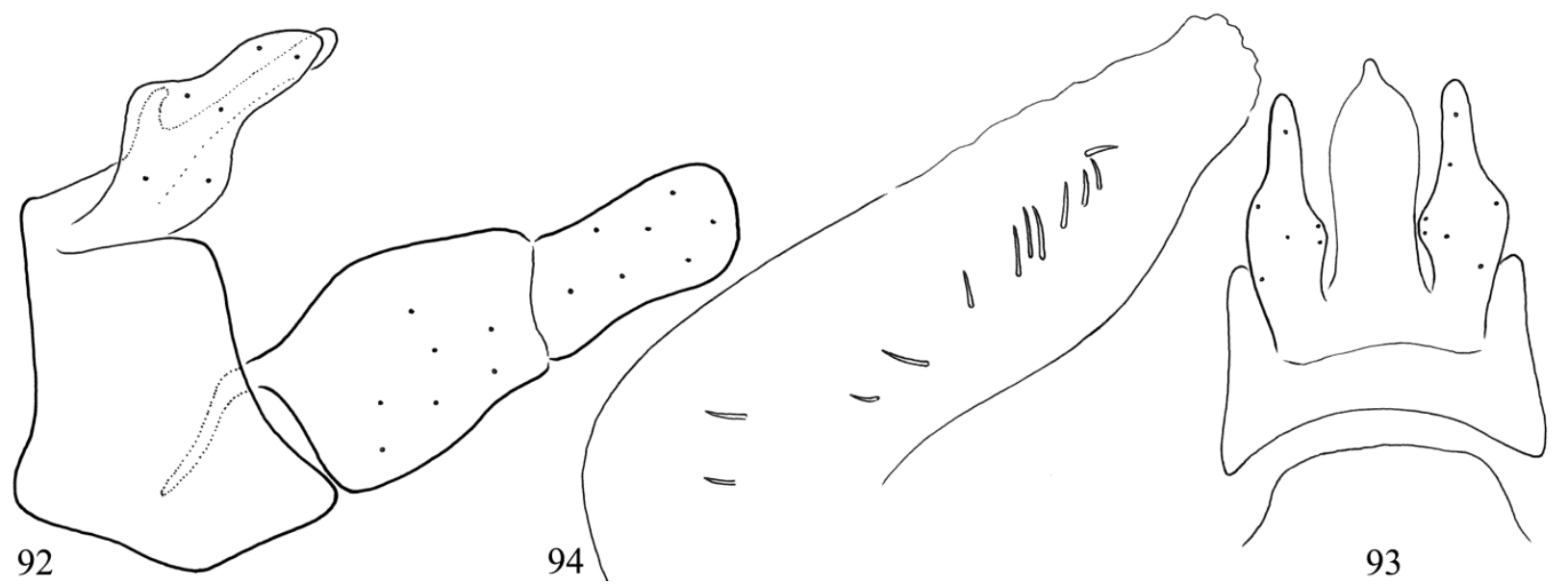

Figurers 92-94. Wormaldia botosaneanui Moretti, 1981. $92=$ male genitalia in left lateral view, $93=$ mesal excision on tergite VIII and segment $\mathrm{X}$ with cerci in dorsal view, 94 = phallic organ with the endothecal spine pattern in left lateral view.

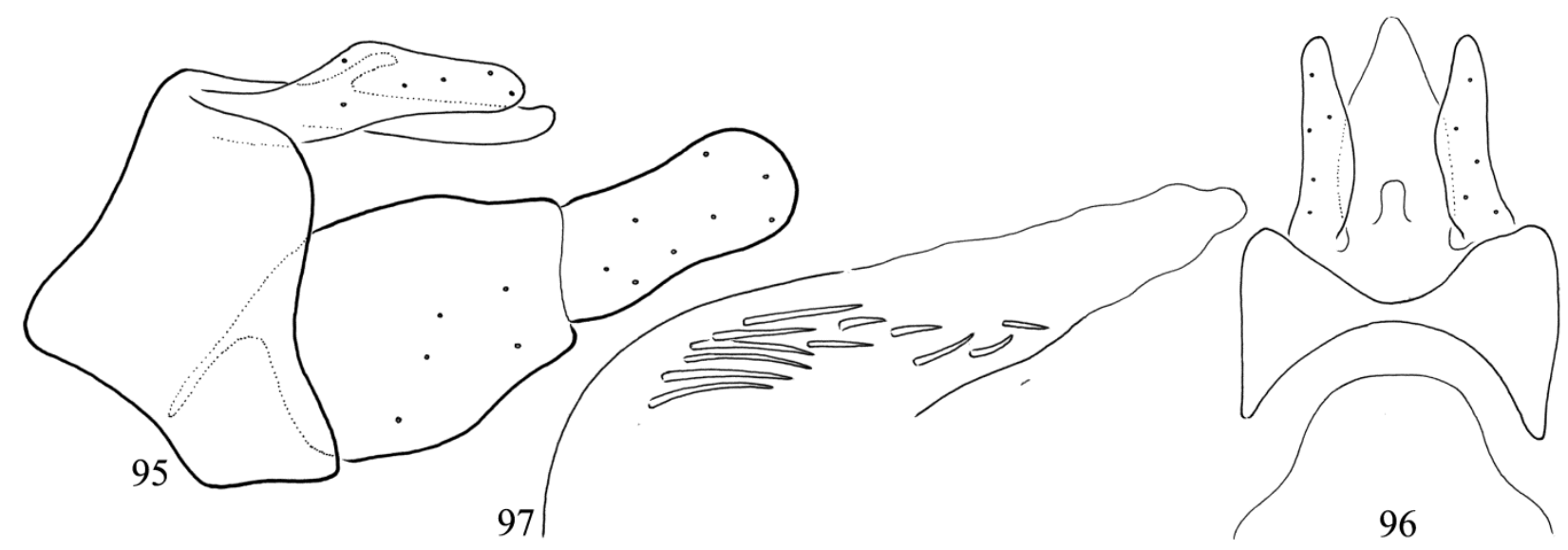

Figures 95-97. Wormaldia copiosa (McLachlan 1868). 95=male genitalia in left lateral view, 96= mesal excision on tergite VIII and segment $\mathrm{X}$ with cerci in dorsal view, $97=$ phallic organ with the endothecal spine pattern in left lateral view.
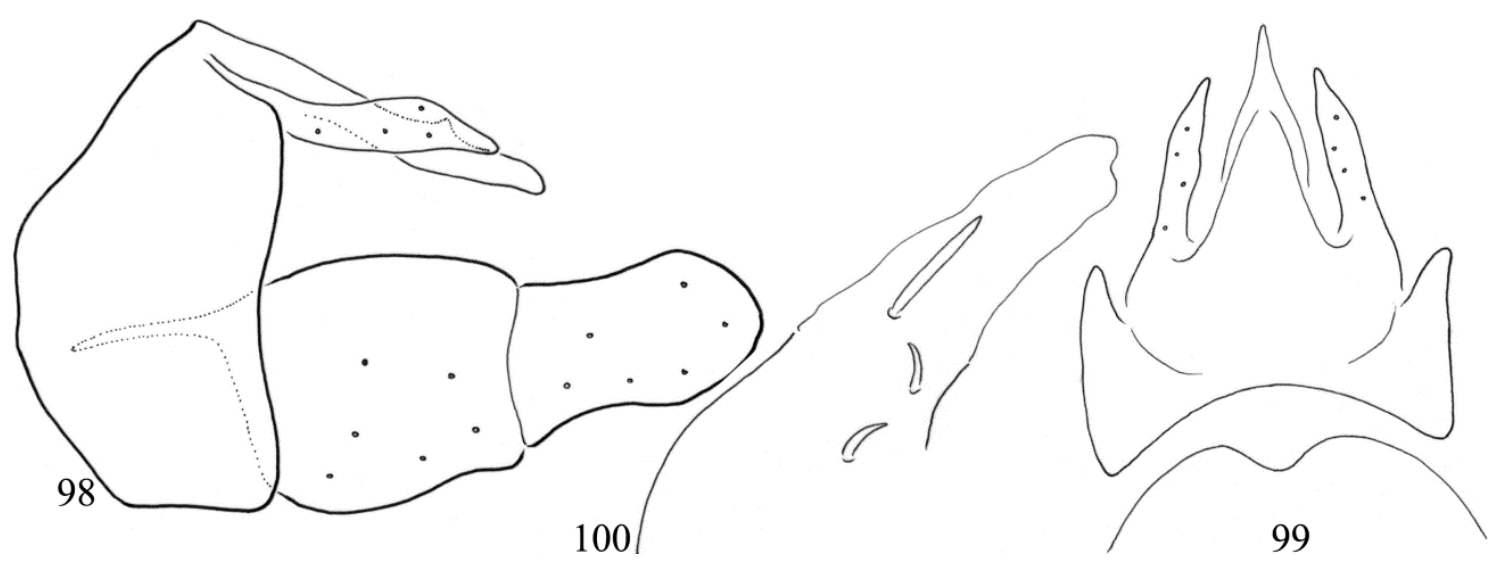

Figures 98-100. Wormaldia kakopetros Malicky, 1972. 98 = male genitalia in left lateral view, $99=$ mesal excision on tergite VIII and segment X with cerci in dorsal view, $100=$ phallic organ with the endothecal spine pattern in left lateral view. 


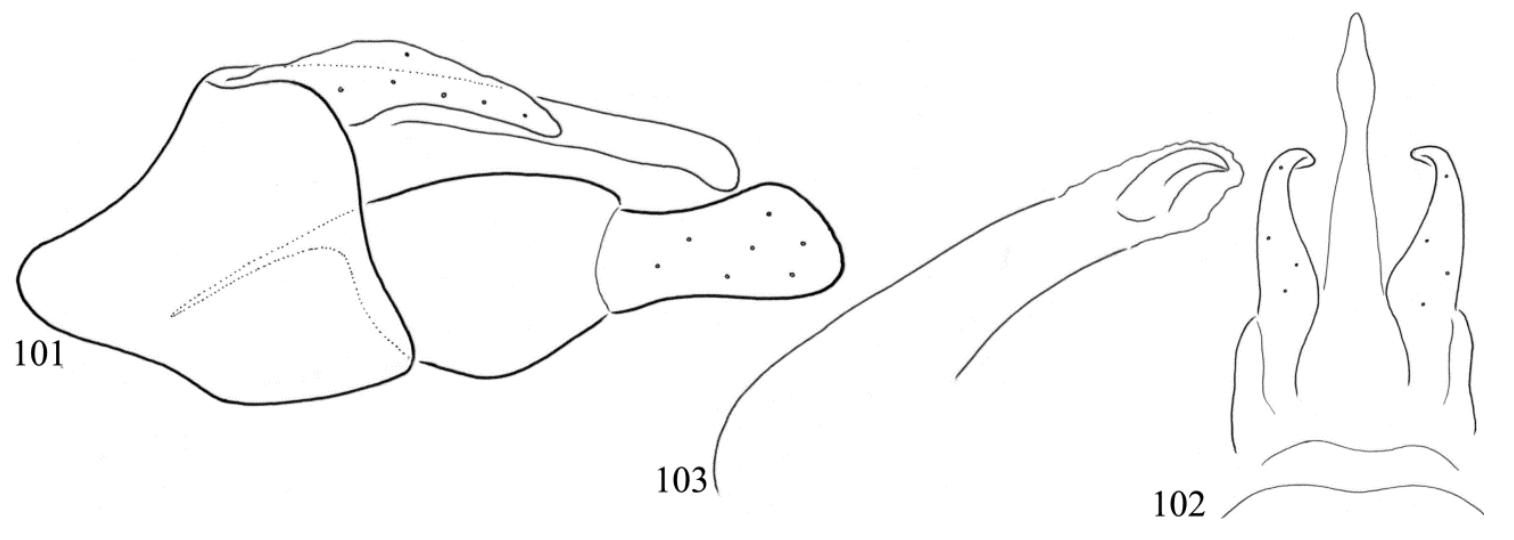

Figures 101-103. Wormaldia marlieri Moretti ,1981. 101 = male genitalia in left lateral view, $102=$ mesal excision on tergite VIII and segment X with cerci in dorsal view, 103 = phallic organ with the endothecal spine pattern in left lateral view.

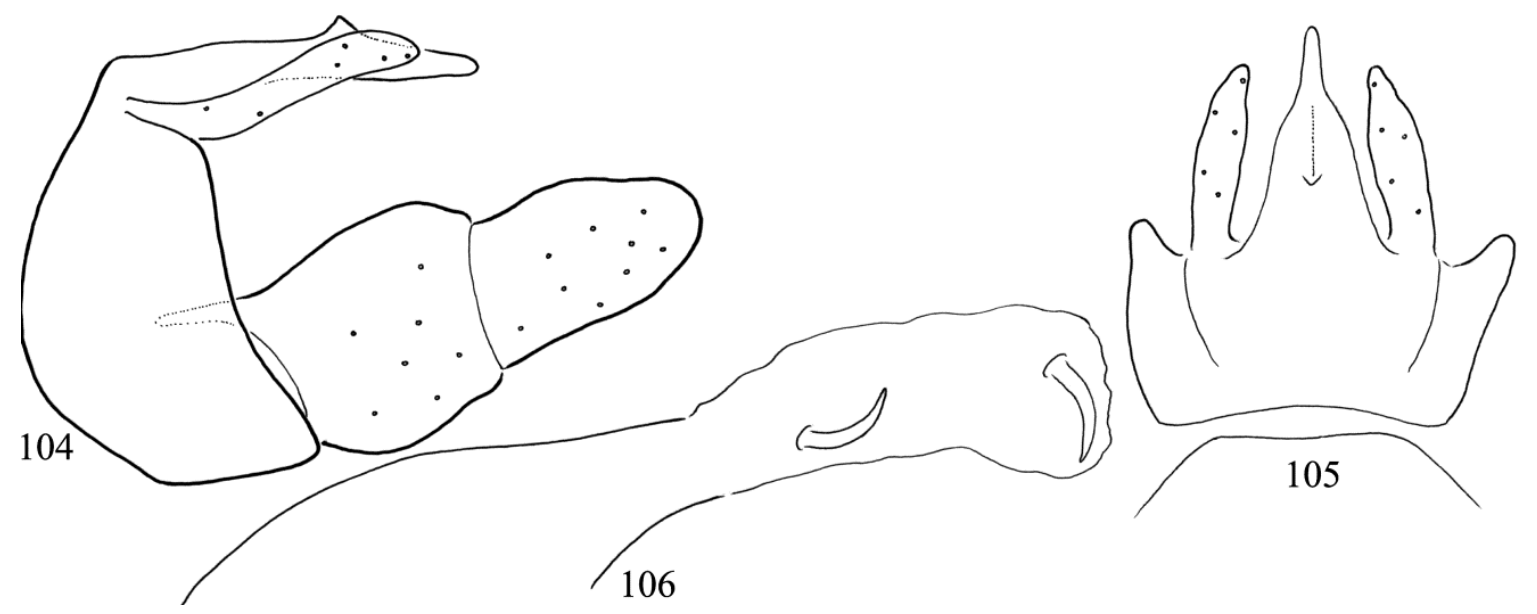

Figures 104-106. Wormaldia parba Oláh, sp. nov. Holotype: $104=$ male genitalia in left lateral view, $105=$ mesal excision on tergite VIII and segment X with cerci in dorsal view, 106 = phallic organ with the endothecal spine pattern in left lateral view.

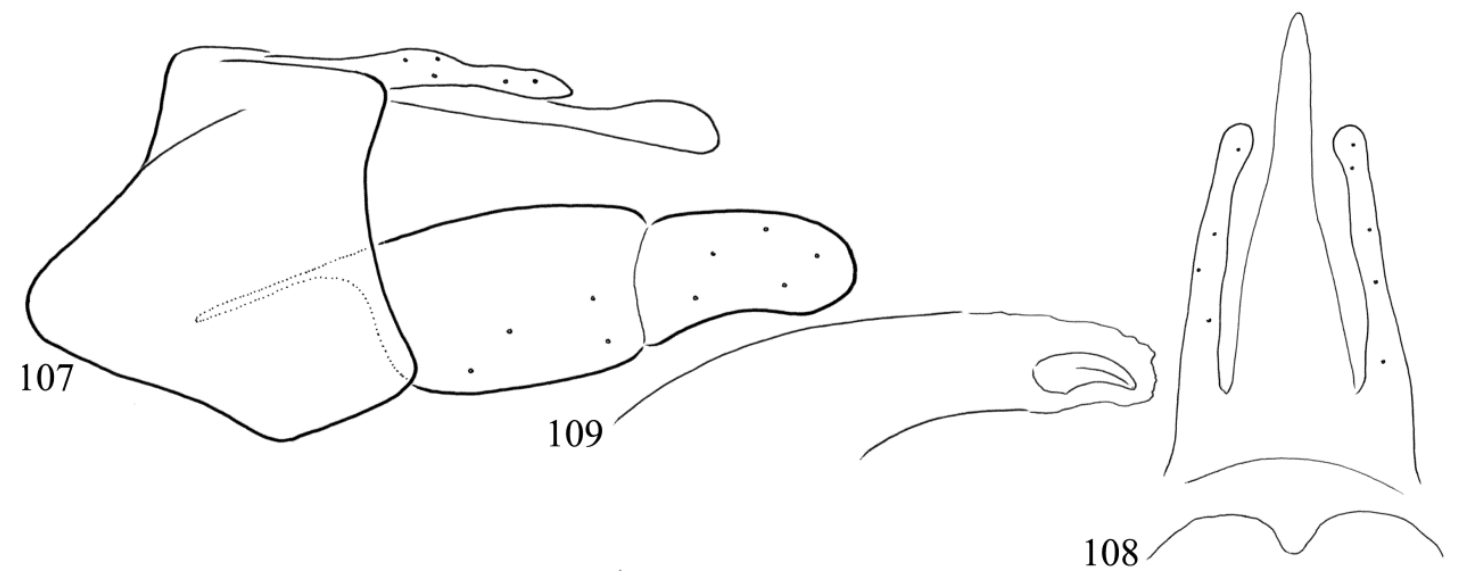

Figures 107-109. Wormaldia pulla (McLachlan, 1878). $107=$ male genitalia in left lateral view, $108=$ mesal excision on tergite VIII and segment X with cerci in dorsal view, 109 = phallic organ with the endothecal spine pattern in left lateral view. 
Gonopods, both coxopodite and harpago short and high (broad); harpagones without middle constriction as visible in lateral view. Phallic organ with eversible membranous endotheca containing two stout spines only; these spines are with enlarged rounded basement and arching body.

Etymology. parba, from "párban", in couple in Hungarian, refers to the two identically shaped large spine present in the endotheca of the phallus.

\section{Wormaldia pulla (McLachlan, 1878)}

(Figures 107-109)

Material examined. Slovakia, Belianske Tatry, Zdiar, Riglany stream, 23.VII.1966, singled leg. J. Oláh (2 males, OPC). Romania, Muntii Lezerului, $1050 \mathrm{~m}$, 45.45 25.02, 4.VIII.2006, leg. M. Bálint (1 male, $\mathrm{OPC}$ ).

\section{Wormaldia vargai Malicky, 1981}

(Figures 110-112)

Material examined. Slovenia, Julian Alp, side stream of Sava Bohinja, 24.VI.1988, sweeping leg. J. Oláh (4 males).

\section{Wormaldia triangulifera species group}

This species group is characterized by the combination (1) of the tapering harpago, (2) of the terminal of segment $\mathrm{X}$ with capitate "head" and with dorsal subapical pointed process and (3) of the endothecal spine pattern with clusters of small spines and with variously shaped and sized spines.

\section{Wormaldia bulgarica species complex}

This species complex is characterized by the combination (1) of the tapering harpago, (2) of the terminal of segment X with capitate "head" and with dorsal subapical pointed process and (3) of the endothecal spine pattern with clusters of small spines and with a single spine.

\section{Wormaldia albanica Oláh, 2010 stat. restit.}

(Figures 113-115)

Wormaldia albanica Oláh, 2010:68-69, "It is closest to $W$. bulgarica described from Bulgaria, but differs by having (1) conspicuous basolateral flange of sclerites present on Xth segment and well visible both in lateral and dorsal view; (2) In lateral view Xth segment has no dorsal excision and no any dorsal subapical hook, tooth or elevation, both present and very conspicuous on $W$. bulgarica; (3) cerci slightly S-forming tapering in dorsal view, not straight and clavate; (4) harpagones longer than coxopodite, not shorter; (5) harpagones slender, tapering and down-curving apically; (6) endotheca with a large spine and a group of four smaller spines besides the long microspine cluster, not only with a single large spine."

Wormaldia bulgarica Novák, 1971: Malicky 2018:43, "Wormaldia albanica Oláh, 2010 was described from one male from Albania and has the typical single spine, but a slightly variable end of segment 10. The type locality is close to the records in the Greek Pindos Mountains: Wormaldia albanica Oláh, 2010 = Wormaldia bulgarica Novák, 1971, nov. syn."

Material examined. Holotype male. Albania, Tepelene county, Tepelene, Uji i Ftohte (Cold Water), 165 m N40 $15.011^{\prime}$ E20 $03.548^{\prime}$, 13.III.2008, leg. Sz. Czigány \& D. Murányi (1 male HNHM).

Remarks. Malicky has synonymised Wormaldia albanica with $W$. bulgarica based on the presence of a single spine in the endothecal spine pattern. However, the single-spined pattern is a character for the entire species complex of $W$. bulgarica. This complex is rather large with eight know and probably many more unknown species. The speciation trait of the head of segment $\mathrm{X}$ is completely different: $W$. albanica has no head at all with subapical dorsal pointed process so pronounced and specifically abbreviated at $W$. subnigra. There are divergences in the endothecal spine pattern as well: the single spines split apically, there are two small spines with split apex differentiated from the long small-spine cluster at W. bulgarica. Moreover, there are several neutral traits diverged: very pronounced basolateral flanges are present on segment $\mathrm{X}$ at $W$. albanica and completely lacking at $W$. bulgarica; harpago longer than coxopodite at $W$. albanica, not shorter; harpago downward curving apicad. Actually $W$. albanica diverged rather far from $W$. bulgarica. Here we reinstate the species status of Wormaldia albanica. stat. restit. 


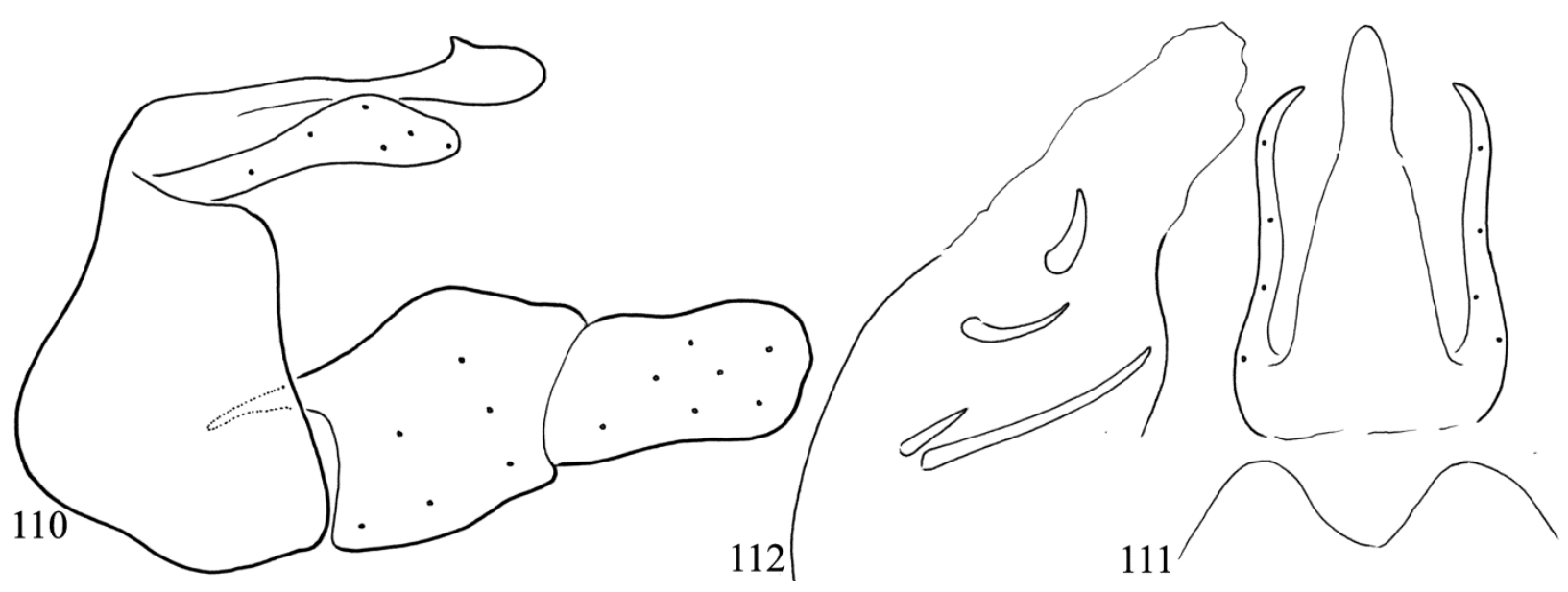

Figures 110-112. Wormaldia vargai Malicky, 1981. $110=$ male genitalia in left lateral view, $111=$ mesal excision on tergite VIII and segment X with cerci in dorsal view, 112 = phallic organ with the endothecal spine pattern in left lateral view.

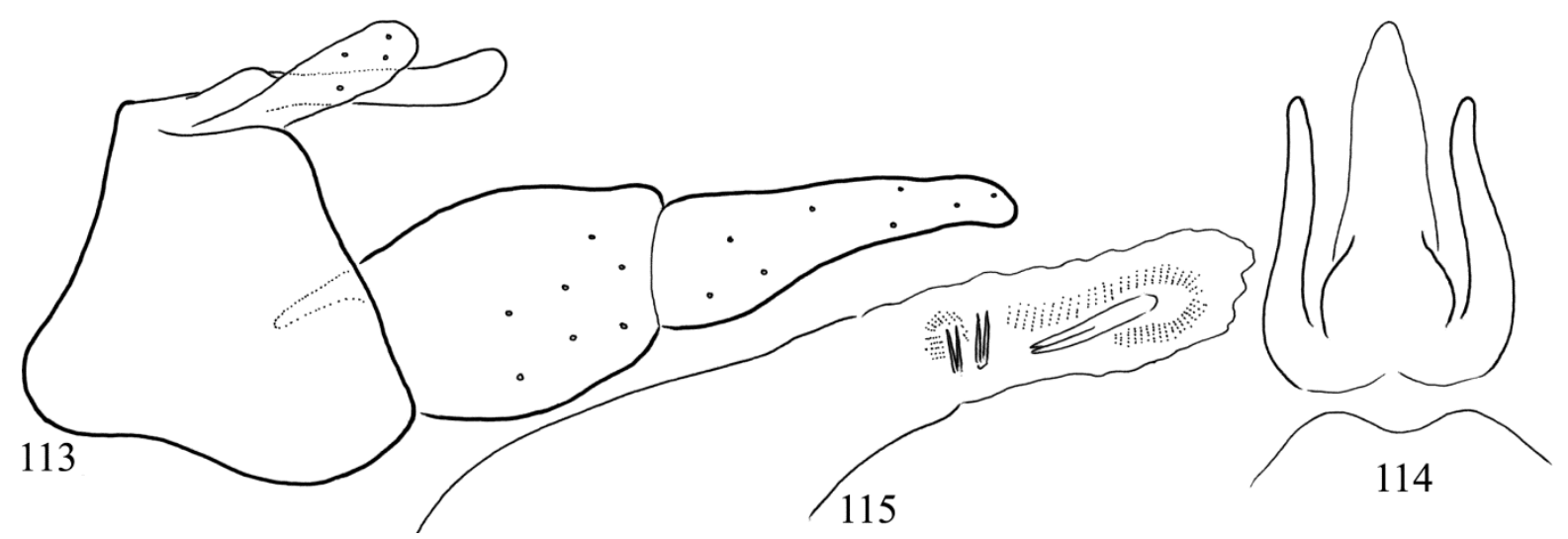

Figures 113-115. Wormaldia albanica Oláh, 2010. $113=$ male genitalia in left lateral view, $114=$ mesal excision on tergite VIII and segment $\mathrm{X}$ with cerci in dorsal view, 115 = phallic organ with the endothecal spine pattern in left lateral view.

Wormaldia bulgarica Novak, 1971 stat. nov.

(Figures 116-118)

Wormaldia khourmai bulgarica Novák, 1971:105-106, "Von der Art W. khourmai unterscheidet sich die neue Subspecies besonders in der Chitinarmatur des Penis und durch das Fehlen der zwei dreieckigen Fortsätze am Apicalrande des VIII. Tergites." "Holotypus: Fundort: Bach bei Rilski Monastir, 14.VII. 1962, 1 đ, in der Sammlung des Autors.”

Remarks. According to the Institute of Entomology, Czech Academy of Sciences, České Budějovice, Czech Republic, the holotype of $W$. bulgarica is damaged and incomplete. The four parts are in one tube: head, pronotum, mesonotum, me- tanotum with proximal abdominal segments. Terminalia are missing. Regarding terminalia there is a letter from Karel Novák wrote to Pavel Chvojka dated November 1992: "I have only the holotype of $W$. bulgarica, unfortunately I have found out now, that it is incomplete - terminalia are missing. But the phallus is mounted on a microscopic slide. ... All paratypes are in the collections of Botosaneanu and Kumanski."

However, repeated search for the slide with the phallus of $W$. bulgarica in the Institute of Entomology was unsuccessful. There is only very small probability that the slide could be discovered in Novák's estate (among documents, papers etc.) in the future. 
Unfortunately after repeated search the paratypes of $W$. bulgarica have not been found neither in the Kumanski's collection of the National Museum of Natural History, Sofia, Bulgaria, nor in the Botosaneanu's collection of Naturalis Biodiversity Center, Zoological Museum, Amsterdam, Netherland. It means, there is only an incomplete holotype of $W$. bulgarica labeled "Wormaldia khourmai / bulgarica Novák / TYPUS / Bach bei Rilki (sic!) Monastir / Rila - Bulgaria leg. Novák / 14.7.1962" remained exist from the entire type material, all collected in the Rila Mountains at around the Rilski Monastir (18 males, 5 females!). The incomplete holotype without genitalia is deposited in the National Museum in Prague henceforward (it was transferred from the Institute of Entomology). Terminalia was lost (Novák 1992 in litt.) and a slide with mounted phallus is missing at present.

Rediagnosis. Fortunately the original drawing prepared from the holotype and redrawn here is detailed enough to distinguish $W$. bulgarica clearly from $W$. silva sp. nov. reported originally as $W$. bulgarica by Kumanski (1979). The speciation trait that is the lateral profile of the head of segment $\mathrm{X}$ is much abbreviated (most abbreviated in the species complex!). It is apple-shaped or even a half-cut apple-shaped, not elongated plum-shaped like at $W$. silva sp. nov.

Notes. Kumanski (1979) has raised Wormaldia khourmai bulgarica ssp. to species rank, but his nomenclatural act was based on misidentified specimens, on those specimens that we describe here as a new species Wormaldia silva sp. nov.

\section{Wormaldia daga Oláh, 2014 stat. restit.}

(Figures 119-121)

Wormaldia daga Oláh, 2014:99-100, “This species with characteristic endothecal spine clusters and narrowing harpagones belongs to the $W$. khourmai, $W$. bulgarica, $W$. balcanica, $W$. mahiri and $W$. erzincanica group of species and most close to $W$. khourmai, but differs by having more swollen apex of segment $\mathrm{X}$, rounded, not truncate apex of cerci and only a single endothecal spine, not three spines."

Wormaldia cf. khourmai Schmid, 1959 (subsp.?): Kumanski 1985:167-168. A single male was described from Bulgaria, Strandzha Mts. as a possible subspecies of $W$. khourmai. According to Kumanski this male from Strandzha is very similar to the single male from Ardesen, Esatern Anatolia.

Wormaldia daga Oláh, 2014: Malicky 2018:43, synonymised $W$. daga with $W$. bulgarica: "Wormaldia daga Oláh, 2014 has the typical distal spine in the phallus. The end of segment 10 is rounded similar to $W$. khourmai, but the area of khourmai is far away, and the individual variation is to be expected. $W$. daga was described from Bulgarian mountains where bulgarica is well known. Wormaldia daga Oláh 2014 = Wormaldia bulgarica Novák 1971, nov. syn.

Material examined. Holotype: Bulgaria, Bosna Mts. Dudenovo, Dudenska Reka, between Vizitza and Novo Panicharevo, 249m, N42 ${ }^{\circ} 10^{\prime} 25^{\prime \prime}$ E27³4'07', 26.VII.2012 at light leg. S. Beshkov \& M. Beshkova (1male, NMNHS). Bulgaria, Strandzha Mts. Malko Tuinovo, 30.VII.1983, leg. K. Kumanski (1 male, NMNHS).

Remarks. Malicky has synonymised Wormaldia daga with $W$. bulgarica based on the presence of a single spine in the endothecal spine pattern. However, the single-spined pattern is a character for the entire species complex of $W$. bulgarica. This complex is rather large with ten known and probably many more unknown species. The speciation trait of the head of segment $X$ is completely different: $W$. daga has very large rounded head without subapical dorsal pointed process so pronounced and specifically abbreviated at $W$. subnigra. There are divergences in the endothecal spine pattern as well: small-spine cluster is very much reduced, not so long elaborated. Moreover, there are several neutral traits diverged: apicomesal excision on tergite VIII very deep, not shallow, cerci with ventromesal turning apex, lacking at $W$. bulgarica. $W$. daga is most close to W. kumanskii sp. nov., but differs by the lateral profile of the head of segment X rounded at $W$. daga and hook-forming at W. kumanskii. Here we reinstate the species status of Wormaldia daga. stat. restit. 


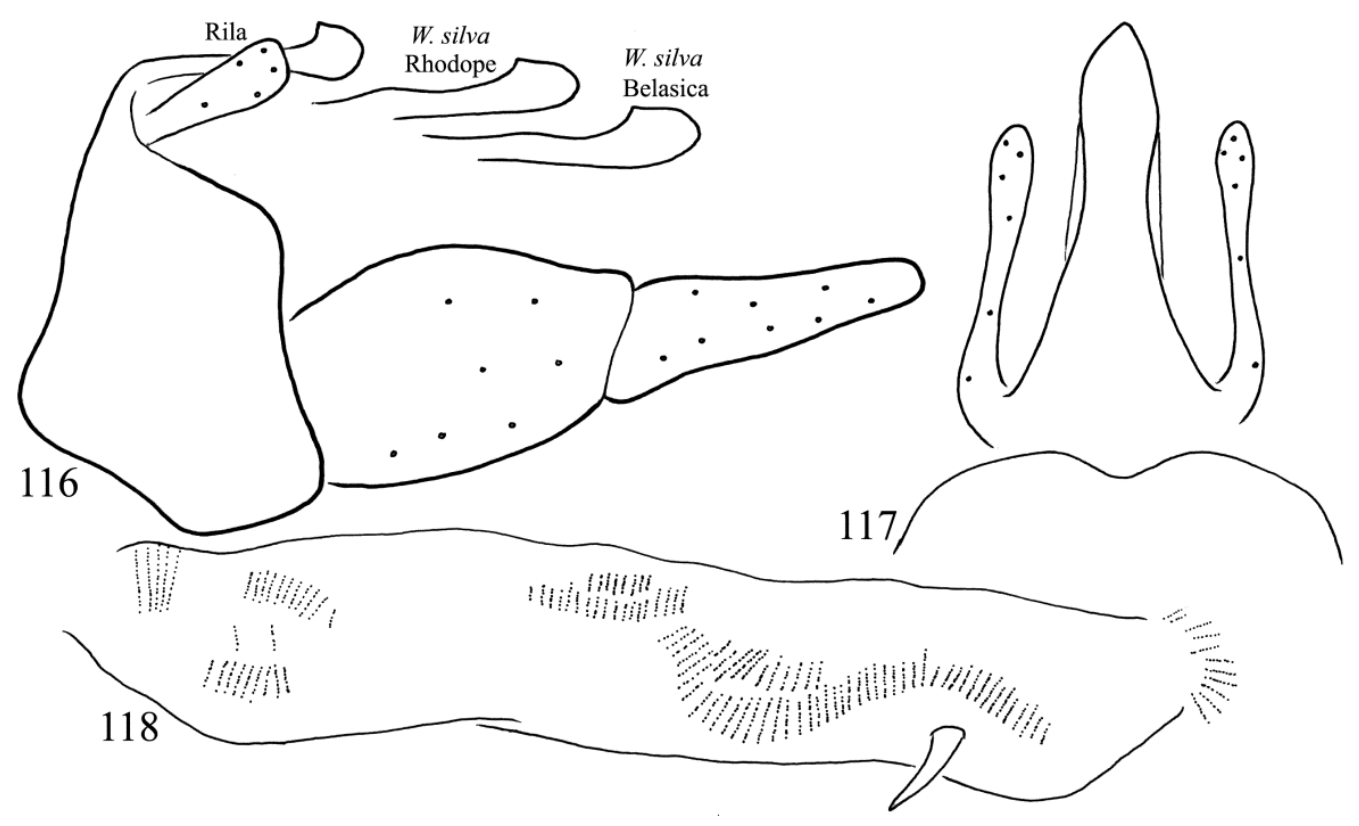

Figures 116-118. Wormaldia bulgarica Novak, 1971. $116=$ male genitalia in left lateral view, $117=$ mesal excision on tergite VIII and segment $\mathrm{X}$ with cerci in dorsal view, $118=$ phallic organ with the endothecal spine pattern in left lateral view.

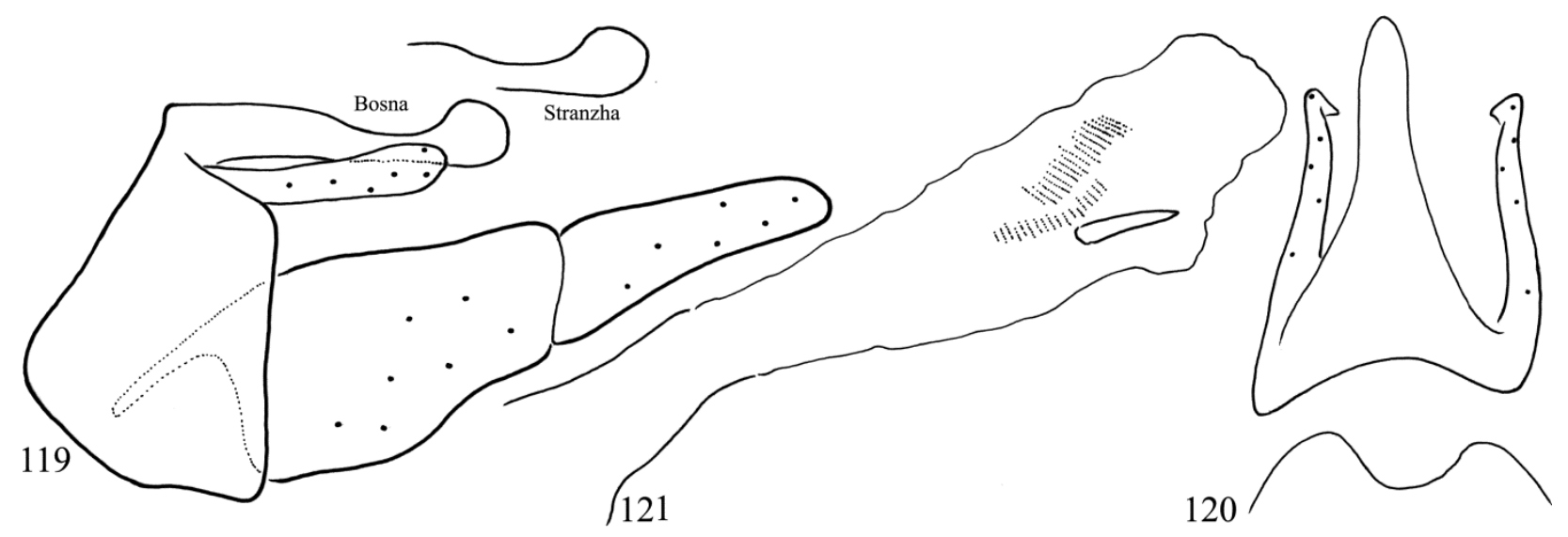

Figures 119-121. Wormaldia daga Oláh, 2014. 119 = male genitalia in left lateral view, $120=$ mesal excision on tergite VIII and segment $\mathrm{X}$ with cerci in dorsal view, 121 = phallic organ with the endothecal spine pattern in left lateral view.

Wormaldia foslana Chvojka \& Oláh, sp. nov.

(Figures 122-124)

Material examined. Holotype: Georgia, Imereti district, Kutaisi, motel, spring area, $42^{\circ} 15^{\prime} 27^{\prime \prime} \mathrm{N}, 42^{\circ}$ 42'35"'E, 158 m, 15.ix.2018, J. Oboňa leg. (1 male, NMPC).

Diagnosis. This new species having tapering harpago belongs to the Wormaldia triangulifera species group and its elaborated small-spine cluster without even a single individual spine relates it to the $W$. bulgarica species cluster, but more characterized and unique by the disintegration of individual spine into spine clusters.

Description. Male (in alcohol). Small castanean brown animal. Sclerites medium brown, setal warts both on head and thorax and legs brown. Maxillary palp formula is I-II-IV-III-V. Forewing length $4 \mathrm{~mm}$. Spur formula is 244 . 
Male genitalia. Tergite VIII with narrow and deep triangular mesal excision on the apical margin. Segment $X$ characterized by narrowing apex in dorsal view, and by lateral profile of rather elongated head, pronounced dorso subapical pointed process; supplied with shallow and short subapical excision; the ending is armed with probably specific pattern of sensory structures of sensilla basiconica (pegs) or sensilla coeloconica (pitted pegs). Cerci with rounded apex in lateral view; in dorsal view without mesad turning apices. Gonopods with coxopodite equal of harpago tapering gradually. Phallic organ with eversible membranous endotheca containing only clusters of spines, one larger basal, one middle with four spines and two small apical clusters.

Etymology. foslana, from "foszló", disintegrated in Hungarian, refers to the disintegrated state of individual spines in the endotheca.

\section{Wormaldia graeca Oláh, 2014 stat. restit.}

(Figures 125-127)

Wormaldia graeca Oláh, 2014:100-102, „This new species differs from Wormaldia kimminsi by having completely different segment X: (1) the dorsal subapical tooth is large rounded, not just visible small and pointed; (2) the middle depression is present and significant, not absent; (3) basolateral pair of flange sclerites well developed, not lacking. Moreover as emphasized by Botosaneanu in his original description the apicomesal excision on tergite VIII is shallow trapezoid. The same excision is deep triangular in $W$. graeca sp. nov. There are significant divergences between the two species also in the endothecal spine systems. The primary large spine is longer, not doubled; there are two cluster of secondary spines, not only a single."

Wormaldia kimminsi Botosaeanu, 1960: Malicky 1977: 68. Greece, Pendayi. Misidentification.

Wormaldia kimminsi Botosaeanu, 1960: Oláh 2010:70. Greece, Phocis prefecture, Vargiani. Misidentification.

Wormaldia kimminsi Botosaneanu, 1960: Malicky 2018:43, "The figure of Wormaldia graeca by Oláh (2014) corresponds well with those of $W$. kimminsi" (Malicky 2004:83), except Segment 10 which is broader in his figure. This may be caused by a different position of the preparation under the microscope, or by individual variability. The phallus includes the typical large, slightly bent sclerite which is accompanied by two bunches of fine spines. I see no reason to make a separate species from this variation. Wormaldia graeca Oláh, $2014=$ Wormaldia kimminsi Botosaneanu, 1960, nov. syn.

Material examined. Holotype: Greece, Phocis county, Vargiani, springs and torrent in the village, 970 m, N38³8.499' E22²5.515', 8.IV.2009, leg. L. Dányi, J. Kontschán \& D. Murányi (1male, HNHM). Greece, Pendayi, N 38 35' E22 5', 900 m, 3.VI.1975 leg. and det. H. Malicky as Wormaldia kimminsi Botosaneanu 1950 (1 male, NBC-ZMAN).

Remarks. In his European Trichoptera Atlas Malicky (2004) has replaced Botosaneanu's original precise drawings of Wormaldia kimminsi of Perister Mts. in Macedonia with his own drawings prepared from $W$. graeca of Pendayi in Greece. Beside the complete drawings from $W$. graeca (Fig. 14-17) he has redrawn the cerci, segment $X$ and the large endothecal spine of $W$. kimminsi holotype (Fig. 18-20). Even on his own drawings both the segment $\mathrm{X}$ and the endothecal spine of $W$. kimminsi differ very clearly from the same structures of W. graeca (Malicky 1977).

Our new diagrammatic drawings indicate the divergences between the two species: the speciation trait of the head of segment $\mathrm{X}$ is clearly diverged, its dorsum is concave at Wormaldia graeca and convex at $W$. kimminsi; the dorsal subapical tooth is large rounded at $W$. graeca, not just visible small and pointed as at $W$. kimminsi; the middle depression is present at $W$. graeca, absent at $W$. kimminsi. There is shape divergence between the two species in the enlarged single spine. Moreover, there are several neutral traits diverged: apicomesal excision on tergite VIII is rounded deep and wide at $W$. graeca, but very shallow and subquadrangular at $W$. kimminsi; very pronounced basolateral flanges are present on segment $\mathrm{X}$ at $W$. graeca and completely lacking at $W$. kimminsi. Here we reinstate the species status of Wormaldia graeca. stat. restit. 


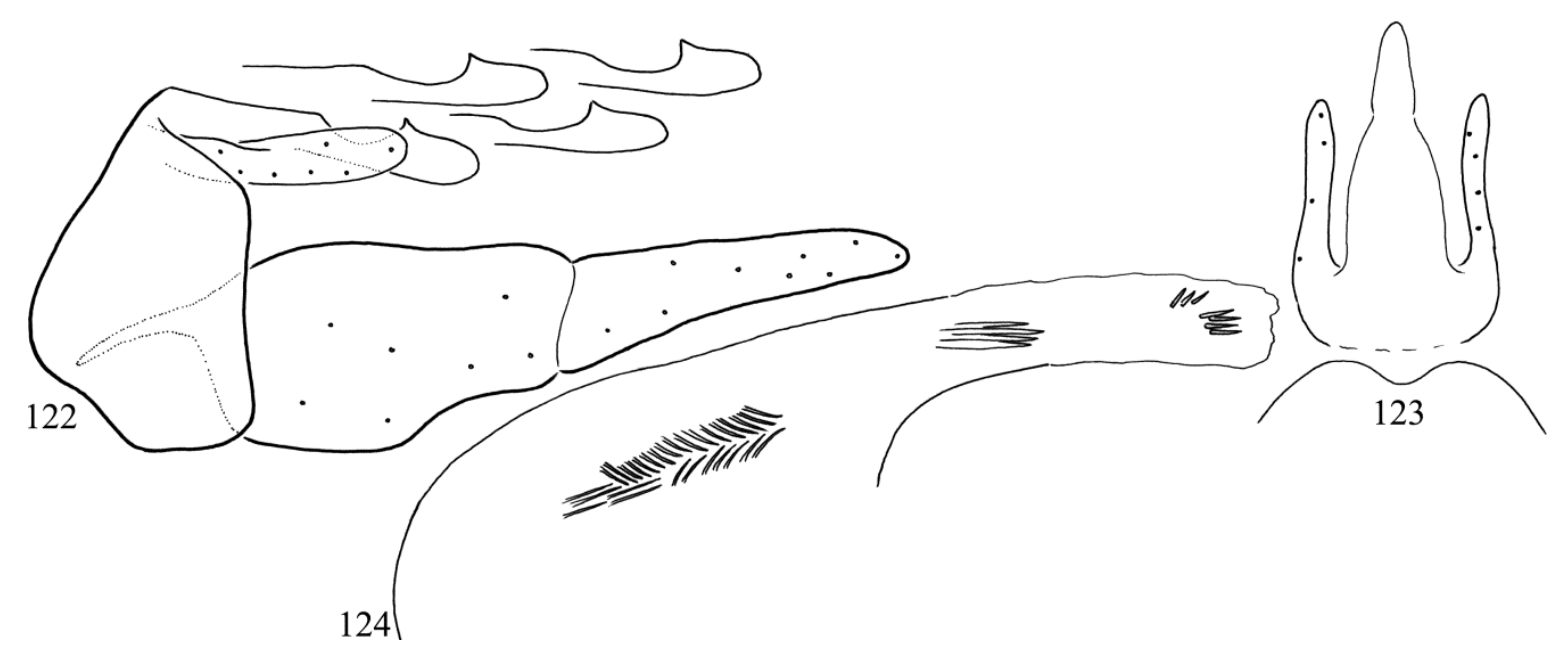

Figures 122-124. Wormaldia foslana Chvojka \& Oláh, sp. nov. Holotype: $122=$ male genitalia in left lateral view, $123=$ mesal excision on tergite VIII and segment X with cerci in dorsal view, 124 = phallic organ with the endothecal spine pattern in left lateral view.

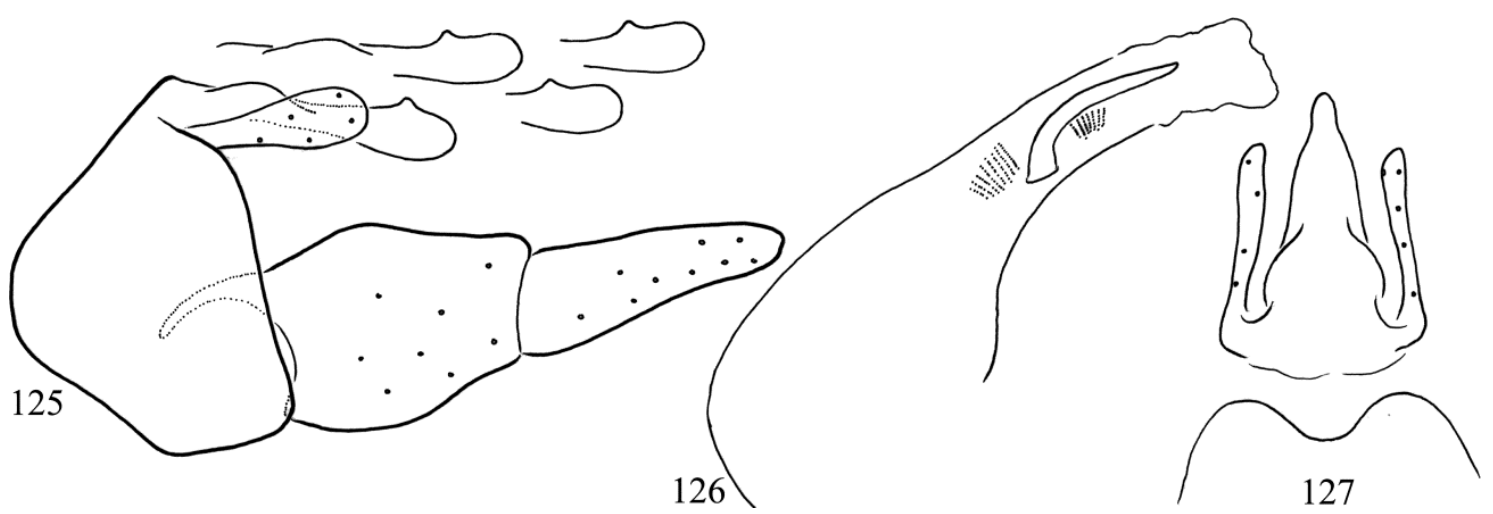

Figures 125-127. Wormaldia graeca Oláh, 2014. 125 = male genitalia in left lateral view, $126=$ mesal excision on tergite VIII and segment $\mathrm{X}$ with cerci in dorsal view, 127 = phallic organ with the endothecal spine pattern in left lateral view.

\section{Wormaldia kimminsi Botosaneanu, 1960}

(Figures 128-130)

Wormaldia triangulifera kimminsi Botosaneanu, 1960: 271, "J'ai eu à ma disposition 40 et $5+$ de Perister 12-16 VIII 1955, que j'ai désigné comme holotype $\hat{\sigma}$, allotype + , paratypes $\hat{\sigma}$ et $O$; holot. $\hat{\sigma}+$ allot. Q: collection Fernand Schmid; $1 \delta^{\lambda}$ parat. +1 ㅇ parat.: Deutsches Entomologisches Institute, Berlin; $2 \hat{\jmath}+2$ + parat..: Collection L. Botosaneanu, Bucarest." "En dépit de sa simplicité, l'armature génitale $\widehat{\delta}$ de cette sous-espèce offre d'excellents caractères qui permettront de la distinguer des trois autres sous-espèces de triangulifera (t. triangulifera McL., t. beaumonti Schmid, t. mosely Kimm.). Par l'armature de l'endothèque de son phallus, notre sous-espèce se rapproche le plus de moselyi Kimm."

Wormaldia kimminsi Botosaneanu, 1960: Malicky 1977:68. Elevated to species.

Material examined. Macedonia, Pelagonia region, Pelister Mts, Nižepole, forest brook below the ski station, N4058.889', E21 ${ }^{\circ} 15.246 ', 1370$ m, 7.05.2014, leg. T. Kovács, D. Murányi (1 male, OPC).

\section{Wormaldia kumanskii Oláh \& Chvojka, sp. nov.}

(Figures 131-133)

Wormaldia khourmai Schmid, 1959 (subsp.?): Kumanski 1979:62-63. A single male from Ardesen, East- 
ern Anatolia was described and drawn as a possible subspecies of $W$. khourmai. Misidentification

Material examined. Holotype, Georgia, Adjaria, Mtirala NP, Chakvistavi ca. $20 \mathrm{~km} \mathrm{NE}$ of Batumi, left tributaries of Chakvistskali riv., $41^{\circ} 40.7^{\prime} \mathrm{N} 41^{\circ} 51.8^{\prime} \mathrm{E}$; 280 m, 30.vi.2013, leg. P. Chvojka (1 male, NMPC). Paratypes: same as holotype (20 males, NMPC; 6 males OPC). Turkey, Trabzon province, Sumela, brooks and springs, 5.vii.1993, leg. P. Chvojka 15 males, 3 females, NMPC, 4 males, OPC). Artvin province, tributary of Murgul Deresi between Borçka and Murgul, 6.vii.1993, leg. P. Chvojka (10 males, NMPC; 2 males, OPC)

Diagnosis. W. kumanskii sp. nov. is most close to $W$. daga, but differs by the lateral profile of the head of segment $\mathrm{X}$; it is hook-forming at $W$. kumanskii and rounded at $W$. daga.

Description. Male (in alcohol). Small castanean brown animal. Sclerites medium brown, setal warts both on head and thorax and legs brown. Maxillary palp formula is I-II-IV-III-V. Forewing length $4 \mathrm{~mm}$. Spur formula is 244 .

Male genitalia. Tergite VIII with deep semicircular mesal excision on the apical margin. Segment X characterized by short hook-forming lateral profile of the head; supplied with deep and short subapical excision; the ending is armed with probably specific pattern of sensory structures of sensilla basiconica (pegs) or sensilla coeloconica (pitted pegs). Cerci with truncate apex in lateral view; in dorsal view pronounced mesad turning apices well visible. Gonopods, with coxopodite having equal length with harpago. Phallic organ with eversible membranous endotheca containing two short small-spine clusters and a single short stout spine; spine is with enlarged rounded basement and slightly arching body.

Etymology. We dedicate this new taxon to the Bulgarian trichopterologist K. P. Kumanski who has first recognised and identified it as Wormaldia khourmai Schmid ssp.

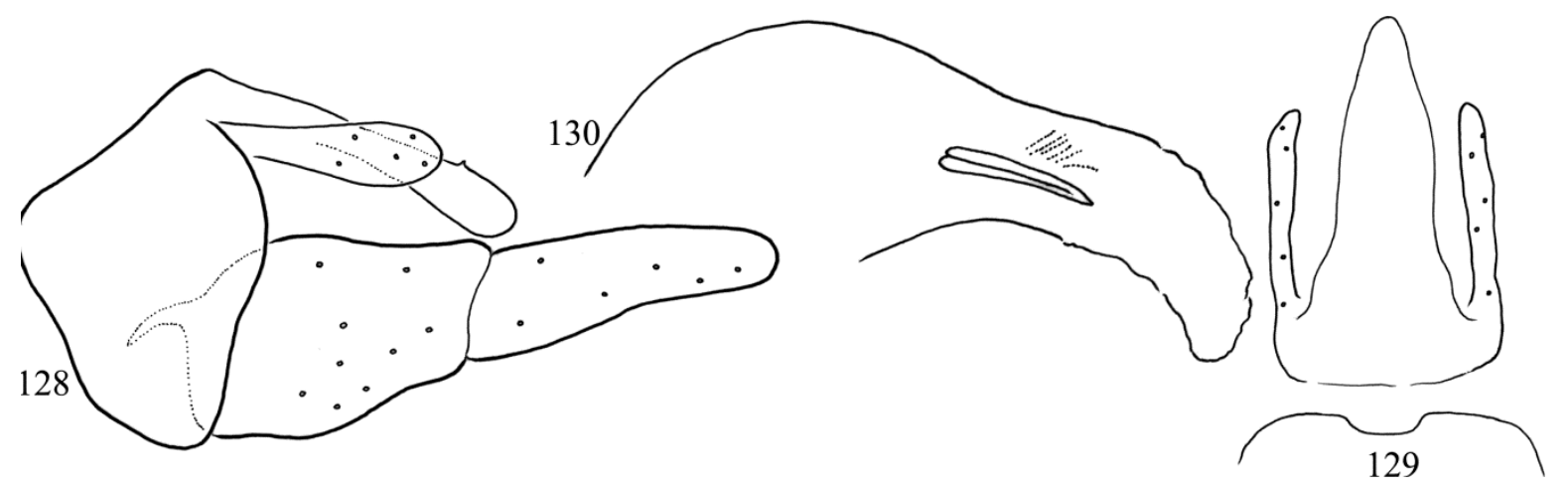

Figures 128-130. Wormaldia kimminsi Botosaneanu, 1960. $128=$ male genitalia in left lateral view, 129=mesal excision on tergite VIII and segment X with cerci in dorsal view, 130 = phallic organ with the endothecal spine pattern in left lateral view.

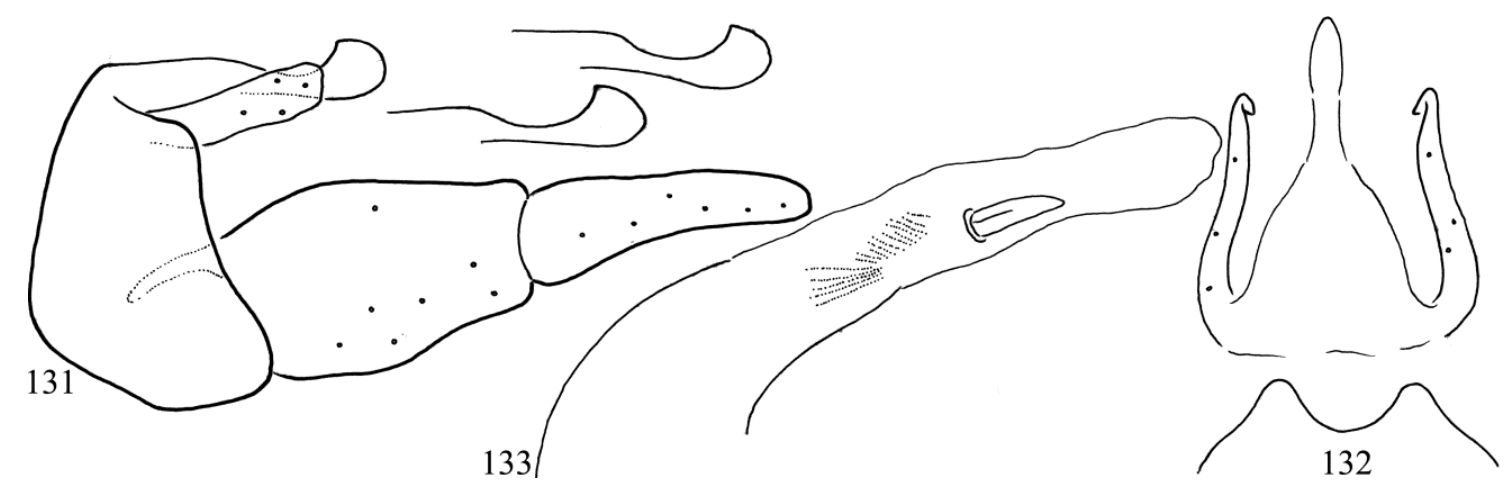

Figures 131-133. Wormaldia kumanskii Oláh \& Chvojka, sp. nov. Holotype: $131=$ male genitalia in left lateral view, $132=$ mesal excision on tergite VIII and segment X with cerci in dorsal view, 133 = phallic organ with the endothecal spine pattern in left lateral view. 


\section{Wormaldia libohova Chvojka \& Oláh, sp. nov.}

\author{
(Figures 134-136)
}

\begin{abstract}
Material examined. Holotype: Albania, Gjirokastër distr., springs near Libohovë, 6.x.1992, leg. P. Chvojka (1male, NMPC).
\end{abstract}

Diagnosis. This new species having tapering harpago belongs to the Wormaldia triangulifera species group and related to the $W$. bulgarica species complex with single large stout spine and long small-spine cluster. The concave dorsum of the head of segment $\mathrm{X}$ is an incongruent, discordant, chimeric character of the $W$. subnigra species complex. Having elongated head of segment X this new species is most close to $W$. foslana sp. nov. of the $W$. bulgarica species complex, but the endothecal spine pattern is completely different.

Description. Male (in alcohol). Small castanean brown animal. Sclerites medium brown, setal warts both on head and thorax and legs brown. Maxillary palp formula is I-II-IV-III-V. Forewing length $4 \mathrm{~mm}$. Spur formula is 244 .

Male genitalia. Tergite VIII with shallow and wide mesal excision on the apical margin. Segment $\mathrm{X}$ characterized by narrowing apex in dorsal view, and by an elongated plum-shaped lateral profile of the head exhibiting some dorsal concavity; dorsal subapical pointed process pronounced; the ending is armed with probably specific pattern of sensory structures of sensilla $b a$ siconica (pegs) or sensilla coeloconica (pitted pegs). Cerci with rounded truncate apex in lateral view; in dorsal view without mesad turning apices. Gonopods, with coxopodite equal with harpago tapering. Phallic organ with eversible membranous endotheca containing long smallspine cluster and a single short stout spine accompanied with a tiny additional stout spine.

Etymology. Named after the type locality.

\section{Wormaldia silva Oláh, sp. nov.}

(Figure 116)

Wormaldia bulgarica Novák, 1971: Kumanski 1979: 61-62, "The following differences separate these two species: bulgarica is evidently smaller (length of fore wing $5 \mathrm{~mm}$ ) than khourmai $(7-8 \mathrm{~mm})$; its dorsal margin of $8^{\text {th }}$ tergite almost without the characteristic for khourmai lateral "epaulets"; no medial dent at the terminal end of the App. superiors; only a single spine in the apex of penis instead of three in khourmai; two groups of spines in the basal part of the penis (indistinctly separated from each other) in addition to the simple (khourmai) range of spines; $10^{\text {th }}$ segment triangular (viewed dorsally), with a rather broad base and feeble lateral enlargements before the apex." Misidentification!

Material examined. Holotype: Bulgaria, Blagoevgrad province, Belasica Mts, Petrič, sping of Lesniska Stream SW of the city, N41 $21.021^{\prime}$, E23 ${ }^{\circ}$ 10.767', 1025 m, 05.05.2014, T. Kovács, D. Murányi (1 male, OPC). Paratypes: same as holotype (2 females, OPC). Bulgaria, Rhodope Mts. streamlet with hydropetric zone, confluent of the Cherna River above Smolyan, 17.VII.1971, leg. and det. K. Kumanski (1 male genitalia in permanent slide, NMNHS).

Diagnosis. The new species is close to Wormaldia bulgarica, but differs by the pronounced divergence of the speciation trait that is the lateral profile of the head of segment X. The head of the segment $\mathrm{X}$ has elongated plum-shaped lateral profile, not abbreviated and not apple-shaped profile of $W$. bulgarica. The plum-shaped lateral profile seems rather stable on the Kumanski's drawings and on the examined and drawn specimens from the Rhodope and Belasica Mountains. $W$. bulgarica is described and known only from the Rila Mountains. We have found similar divergences between the Rila and Belasica populations in the genera of Chaetopteroides (Oláh et al. 2013a) and Drusus (Oláh et. al. 2017a).

Description. Male (in alcohol). Small castanean brown animal. Sclerites medium brown, setal warts both on head and thorax and legs brown. Maxillary palp formula is I-II-IV-III-V. Forewing length $4 \mathrm{~mm}$. Spur formula is 244 .

Male genitalia. Tergite VIII with shallow and narrow triangular mesal excision on the apical margin. Segment $X$ characterized by narrowing apex in dorsal view, and by an elongated plum shaped lateral profile of the head; the ending is armed with probably specific pattern of sensory 


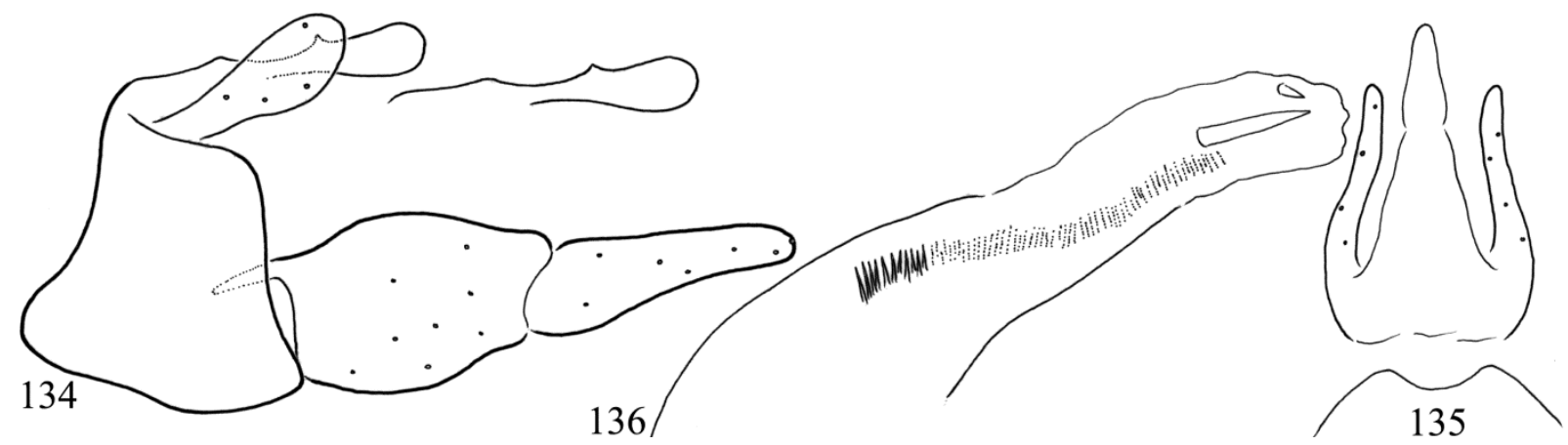

Figures 134-136. Wormaldia libohova Chvojka \& Oláh, sp. nov. Holotype: $134=$ male genitalia in left lateral view, $135=$ mesal excision on tergite VIII and segment X with cerci in dorsal view, $136=$ phallic organ with the endotheca spine pattern in left lateral view.

structures of sensilla basiconica (pegs) or sensilla coeloconica (pitted pegs). Cerci with rounded truncate apex in lateral view; in dorsal view without mesad turning apices. Gonopods, with coxopodite equal with harpago tapering. Phallic organ with eversible membranous endotheca containing long microspine cluster and a single short stout spine.

Etymology. silva, from "szilva", plum in Hungarian, refers to the elongated plum-shaped lateral profile of segment $X$.

\section{Wormaldia khourmai species complex}

This species complex is characterized by the combination (1) of the tapering harpago, (2) the terminal of segment X with capitate "head" and with less pronounced dorsal subapical pointed process and (3) the endothecal spine pattern with clusters of small spines and with three spines.

\section{Wormaldia balcanica Kumanski, 1979}

(Figures 137-139)

Wormaldia khourmai balcanica Kumanski, 1979:6365: partim, specimens from Bulgaria, Strandzha Mts., hygropetric biotope near Katun-dere stream, not far from the bridge on the road Malko TarnovoZvezdetz (about $100 \mathrm{~m}$ a.s.1.) 11.VII.1976, $16 \overbrace{}^{\lambda}$ and 12 ㅇ (leg. Kumanski). Other paratypes represent diverged species: 4 paratypes from Lesbos Island, Greece: $W$. gorba sp. nov., 5 paratypes from Chios Island, Grece: $W$. rona sp. nov., 2 paratypes from Rhodos Island, Greece: W. busa Oláh, 2014, one paratype from Turkey was not available, probably represents a new species.

Wormaldia balcanica Kumanski, 1979: Kumanski 1985:167, stat. nov. Raised to species rank.

Material examined. Paratypes from Bulgaria, Strandzha Mts., hygropetric biotope near Katun-dere stream, not far from the bridge on the road Malko Tarnovo-Zvezdetz (about $100 \mathrm{~m}$ a.s.l.) 11.VII.1976, $16 \hat{\jmath}$ and 12 ㅇ (leg. Kumanski). There were only 9 males and 8 females among the paratypes deposited in NMNHS.

Lectotype designation and deposition. Holotype male was selected from "among the Bulgarian specimens" however without designating any particular specimen. Here we have designated a syntype as the single name-bearing type specimen subsequent to the establishment of the species. Lectotype: Bulgaria, Strandzha Mts., hygropetric biotope near Katun-dere stream, not far from the bridge on the road Malko Tarnovo-Zvezdetz (about $100 \mathrm{~m}$ a.s.1.) 11.VII.1976, leg. Kumanski (1 male, NMNHS). Paralectotypes: same as lectotype ( 4 males, 8 females, NMNHS; 4 males, OPC).

\section{Wormaldia busa Oláh, 2014 stat. restit.}

(Figures 140-141)

Wormaldia busa Oláh, 2014:98-99, "closest to W. balcanica, but differs by having more slender gonopod, harpagones clavate not narrowing, apical head of segment $\mathrm{X}$ without subapical pointed process, but with dorsoapical projection in lateral view; 


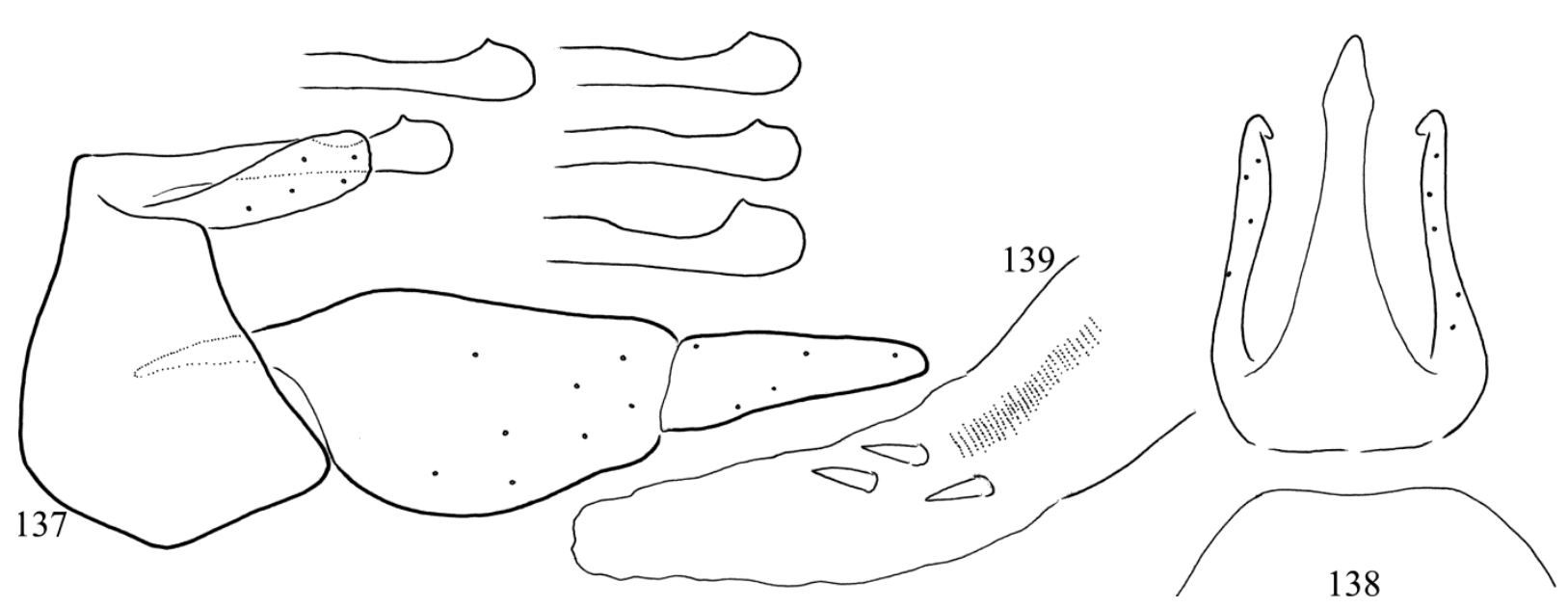

Figures 137-139. Wormaldia balcanica Kumanski, 1979. $137=$ male genitalia in left lateral view with lateral profile of the speciation trait that is the head of segment $\mathrm{X}$ of six paralectotypes, $138=$ mesal excision on tergite VIII and segment $\mathrm{X}$ with cerci in dorsal view, 139 = phallic organ with the endothecal spine pattern in left lateral view.

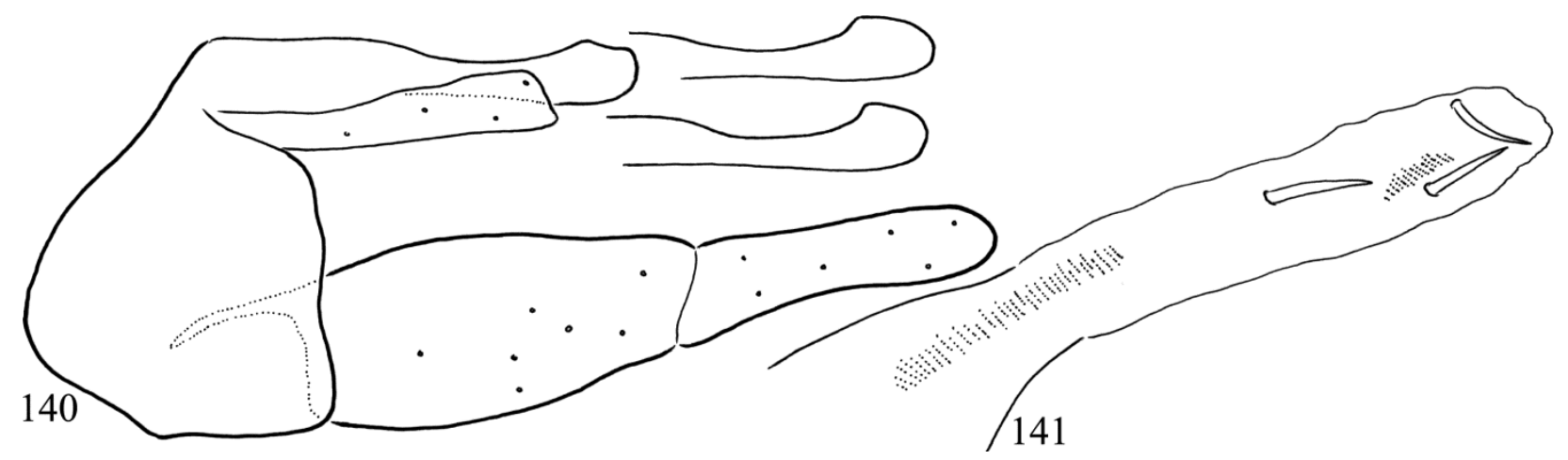

Figures 140-141. Wormaldia busa Oláh, 2014. $140=$ male genitalia in left lateral view with lateral profile of the speciation trait that is the head of segment $\mathrm{X}$ of two more specimens from another population, 141 = phallic organ with the endothecal spine pattern in left lateral view.

cerci with ventromesal pointed tooth just visible, not produced."

Wormaldia balcanica Kumanski, 1979: Malicky 2018: 43, "Wormaldia busa Oláh, 2014 has the three typical straight and sturdy spines in the phallus. The end of segment 10 falls within the variation for $W$. balcanica. W. busa was described from the island of Rhodos where $W$. balcanica was already known (Malicky 2005:74) Wormaldia busa Oláh, 2014 = Wormaldia balcanica Kumanski, 1979, nov. syn." Misidentification!

Material examined. Holotype: Greece, South Aegean, Rhodes regional unit, Apollona, Triana, stream in a gorge with plane trees, $315 \mathrm{~m}, \mathrm{~N} 36^{\circ} 15.261^{\prime}$ E2755.157', 09.11.2012 leg. J. Kontschán, D. Murányi (1male, HNHM). Greece, Rhodos Island, Epta Piges, $28^{\circ} 7^{\prime} \mathrm{E}, 36^{\circ} 15^{\prime} \mathrm{N}, 60 \mathrm{~m}, 9 . \mathrm{V} .1975$, leg. H. Malicky (2 males, NMNHS).

Remarks. Malicky has synonymised Wormaldia busa with $W$. balcanica based on the presence of three spines in the endothecal spine pattern. However, the three-spined pattern is a character for the entire species complex of $W$. khourmai. This complex is rather large with eight known and probably many more unknown species. The speciation trait of the head of segment $\mathrm{X}$ is completely different: $W$. busa has the head without subapical dorsal pointed process. There are divergences in the endothecal spine pattern as well: the tree spines are more slender, not stout as redrawn here from the holotype and from the two males col- 
lected and identified by Malicky as $W$. balcanica . Moreover, there are neutral traits diverged: the ventromesad turning apex of cerci is tiny pointed, almost lacking; the harpago almost parallel-sided, not tapering. Here we reinstate the species status of Wormaldia busa. stat. restit.

\section{Wormaldia gorba Oláh, sp. nov.}

(Figures 142-144)

Wormaldia khourmai balcanica Kumanski 1979:6365: partim, 4 paratypes from Lesbos Island, Greece. Misidentification!

Wormaldia balcanica Kumanski 1985:167: partim, specimens from Lesbos Island, Greece. Misidentification!

Wormaldia balcanica Kumanski 1985. Malicky 2005: 74: partim, specimens from Lesbos Island, Greece. Misidentification!

Material examined. Examined 4 male paratypes of Wormaldia balcanica from Lesbos Island, Greece deposited in NMNHS. Holotype. Greece, Lesbos Island, Plomari, Lesbos, $7 \mathrm{~km}$ E. $26^{\circ} 26^{\prime} \mathrm{E}, 38^{\circ} 59^{\prime} \mathrm{N}, 110 \mathrm{~m}$, 31.V.1975, leg. H. Malicky $11 \overbrace{}^{\Uparrow}$ (1 male, NMNHS). Paratypes: same as holotype (1 male, NMNHS; 2 males, OPC).

Diagnosis. This new species having tapering harpago belongs to the Wormaldia triangulifera species group and having long small-spine cluster with three stout spines belongs to the Wormaldia khourmai species group. Wormaldia gorba sp. nov., an allopatric species known only from Lesbos Island, Greece was listed by Kumanski as paratypes of Wormaldia khourmai balcanica subspecies, a subspecies described with holotype from Stransha Mts., Bulgaria. Wormaldia gorba sp. nov. is most close to $W$. rona sp. nov. but differs by having shallow, rounded excision on tergite VIII, not deep triangular; lateral profile of segment $\mathrm{X}$ is upward curving, with slight and long subapical dorsal excision, not simply flat with short subapical dorsal excision; cerci pointed ventrad, not truncate; harpago tapering, not parallel-sided.

Description. Male (in alcohol). Small castanean brown animal. Sclerites medium brown, setal warts both on head and thorax and legs brown. Maxillary palp formula is I-II-IV-III-V. Forewing length $4 \mathrm{~mm}$. Spur formula is 244 .

Male genitalia. Tergite VIII with very shallow rounded mesal excision on the apical margin. Segment X characterized by narrowing apex in dorsal view, and by a rather upward curving configuration in lateral view; supplied with shallow and long subapical excision; rounded apex upward arching; the ending is armed with probably specific pattern of sensory structures of sensilla basiconica (pegs) or sensilla coeloconica (pitted pegs). Cerci with ventrad pointed apex in lateral view; in dorsal view small mesad turning apices visible. Gonopods, with coxopodite slightly longer than harpago that is tapering, not parallelsided. Phallic organ with eversible membranous endotheca containing long microspine cluster and three short stout and almost equal spines; these spines are with enlarged rounded basement and arching body.

Etymology. gorba, from "görbe", curved, crooked in Hungarian, refers to the shape of segment $\mathrm{X}$ with upward arching apical region.

\section{Wormaldia kera Oláh, sp. nov.}

(Figures 145-147)

Material examined. Holotype, Georgia, RachaLechkhumi \& Kvemo Svaneti region, Svaneti range, Benieri, spring outlet and open brook, N42 $48.638^{\prime}$ E4306.654', 1335m, leg. D. Murányi et al., 16.IX. 2018 (1 male, OPC).

Diagnosis. This new species having tapering harpago belongs to the Wormaldia triangulifera species group and having long small-spine cluster with three stout spines belongs to the Wormaldia khourmai species complex. Most close to $W$. sima, but the speciation trait that is the head of segment $\mathrm{X}$ is almost regularly rounded at $W$. kera, not with triangular dorsal subapical pointed process of $W$. sima. The spine shapes of the endotheca are different. The apicomesal excision on tergite VIII is deep and wide subquadrangular with pronounced lateral lobes, not triangular without lateral lobes. 


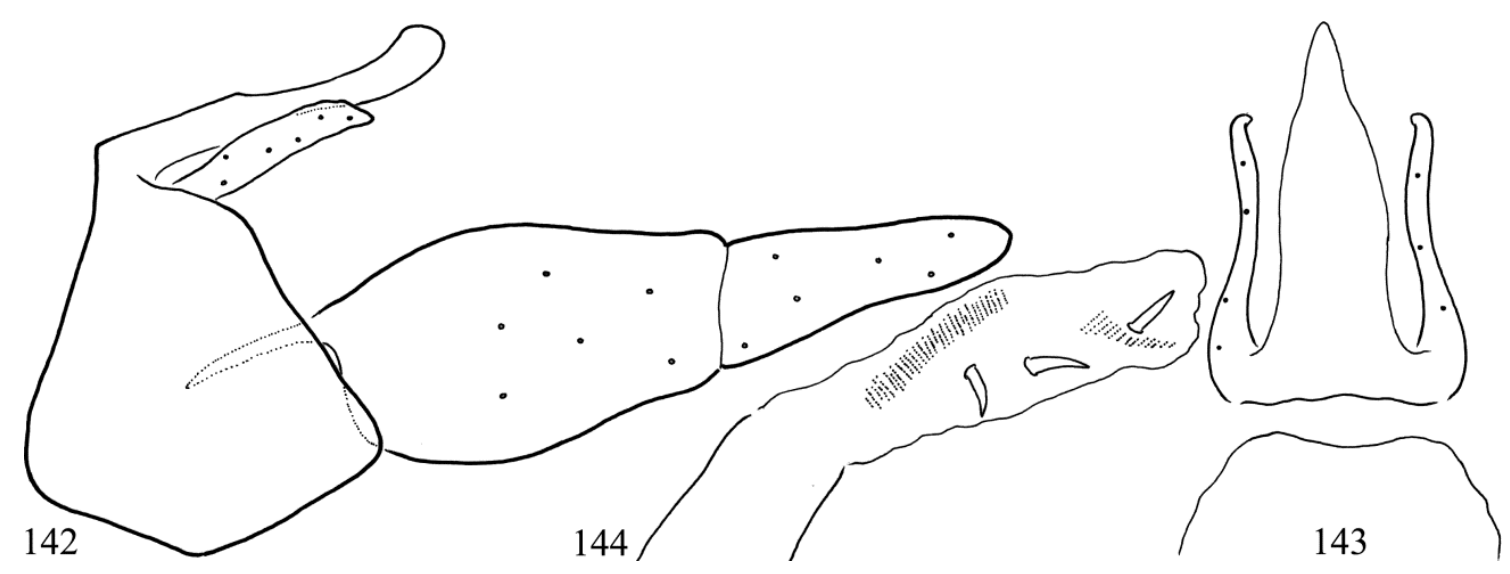

Figures 142-144. Wormaldia gorba Oláh, sp. nov. Holotype: $142=$ male genitalia in left lateral view, $143=$ mesal excision on tergite VIII and segment X with cerci in dorsal view, 144 = phallic organ with the endothecal spine pattern in left lateral view.

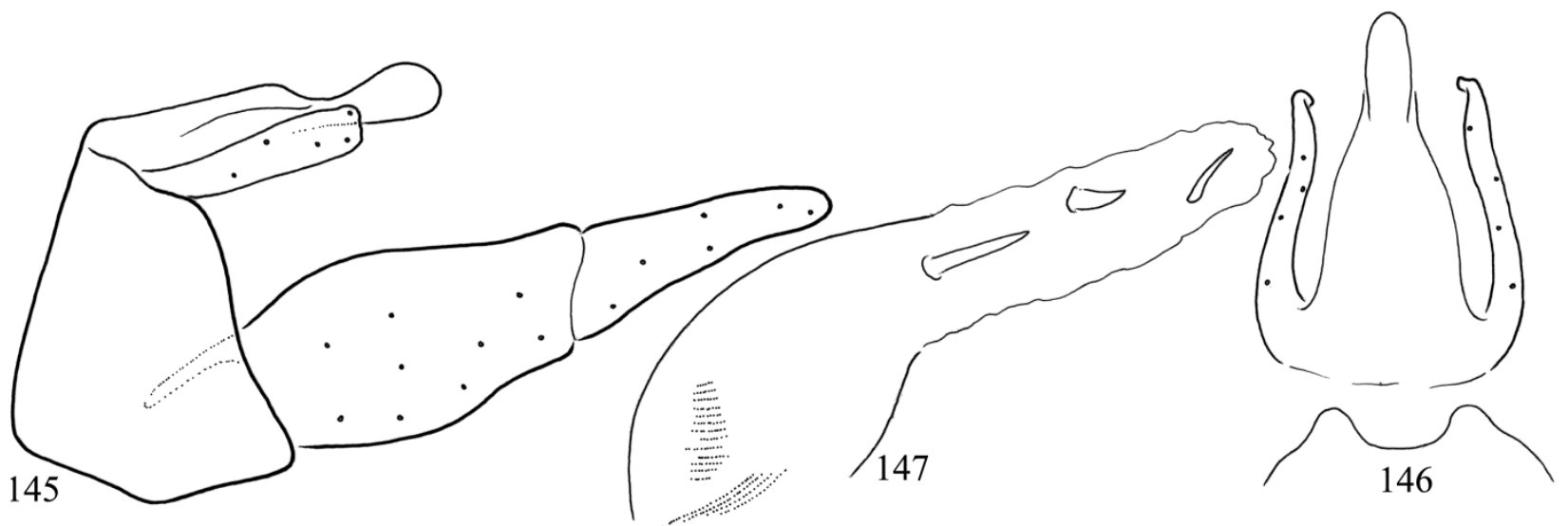

Figures 145-147. Wormaldia kera Oláh, sp. nov. Holotype: $145=$ male genitalia in left lateral view, $146=$ mesal excision on tergite VIII and segment X with cerci in dorsal view, 147 = phallic organ with the endothecal spine pattern in left lateral view.

Description. Male (in alcohol). Small castanean brown animal. Sclerites medium brown, setal warts both on head and thorax and legs brown. Maxillary palp formula is I-II-IV-III-V. Forewing length $4 \mathrm{~mm}$. Spur formula is 244 .

Male genitalia. Tergite VIII with deep and wide mesal excision on the apical margin. Segment $\mathrm{X}$ characterized by narrowing apex in dorsal view, and by a rather rounded head configuration in lateral view; supplied with deep and short subapical excision; the ending is armed with probably specific pattern of sensory structures of sensilla basiconica (pegs) or sensilla coeloconica (pitted pegs). Cerci with truncate apex in lateral view; in dorsal view pronounced mesad turning apices well visible. Gonopods, with coxopodite longer than harpago that is tapering and slightly down- ward curving. Phallic organ with eversible membranous endotheca containing two short smallspine clusters and three spines; these spines are differently shaped.

Etymology. kera, from "kerek", circular in Hungarian, refers to the shape of the head of segment $X$.

\section{Wormaldia khourmai Schmid, 1959}

(Figures 148-150)

Material examined. Iran, Gilan Province, Elburz Mts. Talysh Mt. Masula River, small left side tributary, 12.VIII.1990, singled leg. J. Oláh (3 males, OPC). Iran, North Iran, Mazandaran province, stream $10 \mathrm{~km} \mathrm{~S}$ of 
Galugah, 364 $41.1^{\prime} \mathrm{N}, 53^{\circ} 46.3^{\prime} \mathrm{E}$; $550 \mathrm{~m}, 30 . \mathrm{v} .2006$, leg. P. Chvojka (1 male, NMPC; 1 male, OPC). Iran, North Iran, Golestan province, stream $2 \mathrm{~km} \mathrm{E}$ Tunel-eGolestan, $37^{\circ} 22.2^{\prime} \mathrm{N} 55^{\circ} 59.5^{\prime} \mathrm{E} ; 850 \mathrm{~m}, 26 . v .2006$, leg. P. Chvojka, (11 males, 36 females, NMPC; 4 males, OPC). Iran, North Iran, Golestan province, streamlet 8 $\mathrm{km}$ SE Galikash, $37^{\circ} 12.9^{\prime} \mathrm{N}, 5^{\circ} 29.1^{\prime} \mathrm{E} ; 880 \mathrm{~m}, 28$.v. 2006, leg. P. Chvojka, (12 males, 7 females, NMPC; 4 males, OPC). Iran, North Iran, Gilan province, stream, $5 \mathrm{~km}$ from Kakrud S of Rudsar, $36^{\circ} 51.2^{\prime} \mathrm{N} 50^{\circ} 13,9^{\prime} \mathrm{E}$; 670 m, 2.vi.2006, leg. P. Chvojka, (2 males, 4 females, NMPC; 1 male, OPC).

\section{Wormaldia rona Oláh, sp. nov.}

\section{(Figures 151-153)}

Wormaldia khourmai balcanica Kumanski, 1979:6365, 5 paratypes from Chios Island, Greece. Misidentification!

Wormaldia balcanica Kumanski, 1979: Kumanski 1985:167, Malicky 2005:74, partim: specimens from Chios Island, Greece. Misidentification!

Material examined. 5 male paratypes of Wormaldia balcanica from Chios Island, Greece deposited in NMNHS. Holotype. Greece, Chios Island, Kaminia, W. Chios, $25^{\circ} 56^{\prime} \mathrm{E}, 38^{\circ} 33^{\prime} \mathrm{N}, 410 \mathrm{~m}, 18$.V.1975, leg. H. Malicky 20ðิ, 15, (1 male, NMNHS). Paratypes: same as holotype (2 males, NMNHS; 2 males, OPC).

Diagnosis. This new species having tapering harpago belongs to the Wormaldia triangulifera species group and having long small-spine cluster with three stout spines belongs to the Wormaldia khourmai species complex. Wormaldia rona sp. nov., an allopatric species known only from Chios Island, Greece was listed as paratypes of Wormaldia khourmai balcanica subspecies, a subspecies described with holotype from Strandzha Mts., Bulgaria. Wormaldia rona sp. nov. differs from $W$. balcanica by having deep triangular excision on tergite VIII, not just discernible shallow; lateral profile of segment $\mathrm{X}$ simply flat with slight and short subapical dorsal excision, without pronounced capitate ending, not without subapical dorsal excision and not with pronounced capitate head; cerci more truncate, not rounded; harpago almost parallel-sided, not tapering.
Description. Male (in alcohol). Small castanean brown animal. Sclerites medium brown, setal warts both on head and thorax and legs brown. Maxillary palp formula is I-II-IV-III-V. Forewing length $4 \mathrm{~mm}$. Spur formula is 244 .

Male genitalia. Tergite VIII with deep triangular mesal excision on the apical margin. Segment $X$ characterized by narrowing apex in dorsal view, and by a rather flat configuration in lateral view; supplied with shallow and short subapical excision; the ending is armed with probably specific pattern of sensory structures of sensilla basiconica (pegs) or sensilla coeloconica (pitted pegs). Cerci with truncate apex in lateral view; in dorsal view pronounced mesad turning apices well visible. Gonopods, with coxopodite longer than harpago tapering only slightly, almost parallel-sided. Phallic organ with eversible membranous endotheca containing long microspine cluster and three short stout and almost equal spines; these spines are with enlarged rounded basement and arching body.

Etymology. rona, from "róna", flat in Hungarian, refers to the flat lateral profile of segment $\mathrm{X}$ without upward arching apical region.

\section{Wormaldia sima Oláh \& Chvojka, sp. nov.}

$$
\text { (Figures 154-156) }
$$

Material examined. Holotype, Georgia, Imereti region, Racha range, Tkibuli, karst spring in forest below Nakerala Pass, N42²2.928', E4301.070', 995 m, 18.IX.2018, leg. D. Murányi et al. (1 male, OPC). Paratype: Georgia, Imereti district, Pereval Nakeral'skii pass, tributary of Tkibula River, $42^{\circ} 22^{\prime} 55^{\prime \prime} \mathrm{N}, 43^{\circ} 01^{\prime}$ 07"E, 1016 m, 18.IX.2018, J. Oboňa leg. (1 male, NM PC). Georgia, Svanetia, stream N of Mestia, $43^{\circ} 03^{\prime} \mathrm{N}$, 4243.1'E, 1510-1700 m, 5.VII.2013, leg. P. Chvojka (3 males, NMPC; 2 males, OPC). Georgia, Svanetia, brook, left tributary of Mulkhura riv. SE of Mestia, $43^{\circ} 02.4^{\prime} \mathrm{N}, 42^{\circ} 45.5^{\prime} \mathrm{E}, 1490 \mathrm{~m}, 5 . \mathrm{VII} .2013$, leg. P. Chvojka (3 males, NMPC; 2 males, OPC). Georgia, Svanetia, brook, left tributary of Mulkhura riv. SE of Mestia, $43^{\circ} 02.5^{\prime} \mathrm{N} 42^{\circ} 45.8^{\prime} \mathrm{E} ; 1500 \mathrm{~m}, 5$.VII.2013, leg. P. Chvojka (4 males, NMPC). Georgia, Svanetia, brook, left tributary of Mulkhura riv. SE of Mestia, $43^{\circ} 02.5^{\prime} \mathrm{N}, 42^{\circ} 46.3^{\prime} \mathrm{E}, 1510 \mathrm{~m}, 5 . \mathrm{VII} .2013$, leg. P. Chvojka (4 males, NMPC; 3 males, OPC) 


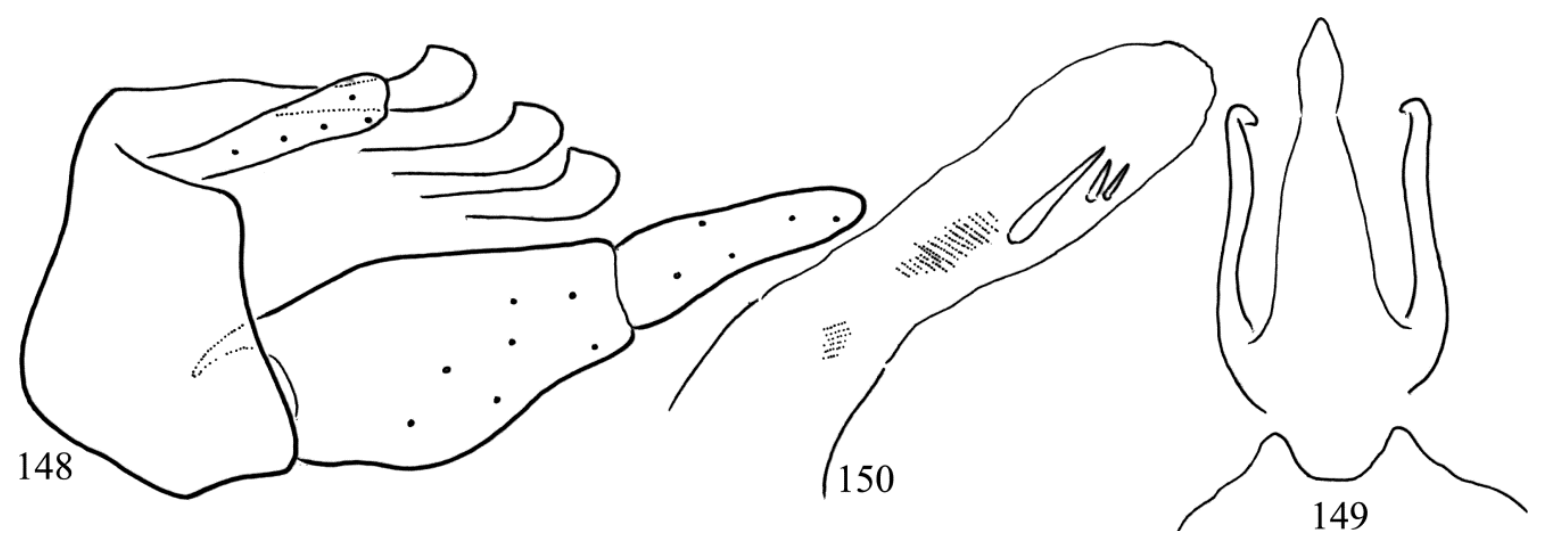

Figures 148-150. Wormaldia khourmai Schmid, 1959. $148=$ male genitalia in left lateral view, $149=$ mesal excision on tergite VIII and segment $\mathrm{X}$ with cerci in dorsal view, $150=$ phallic organ with the endothecal spine pattern in left lateral view.

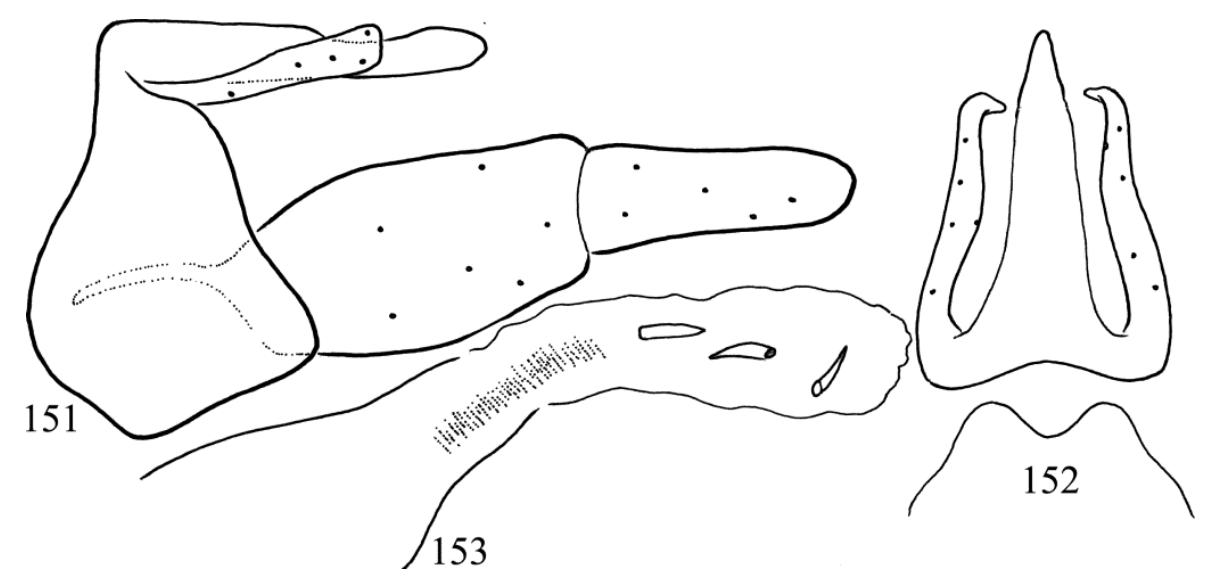

Figures 151-153. Wormaldia rona Oláh, sp. nov. Holotype: 151 = male genitalia in left lateral view, $152=$ mesal excision on tergite VIII and segment X with cerci in dorsal view, 153 = phallic organ with the endothecal spine pattern in left lateral view.

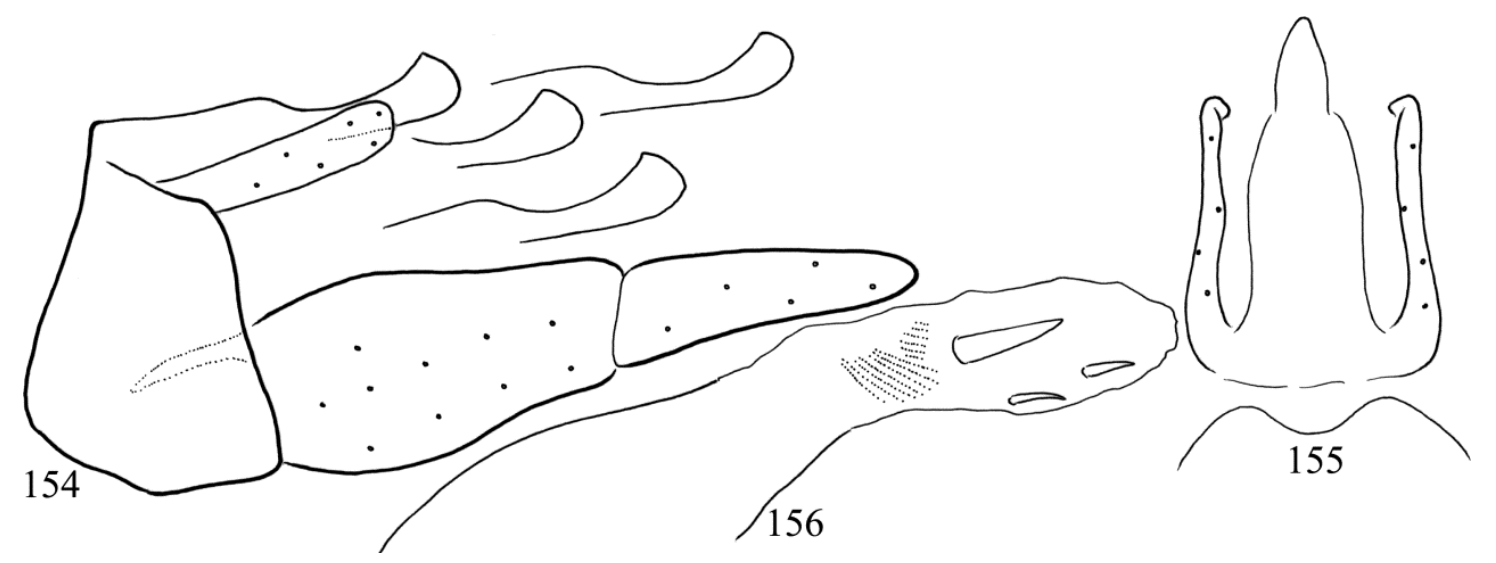

Figures 154-156. Wormaldia sima Oláh \& Chvojka, sp. nov. Holotype: $154=$ male genitalia in left lateral view, $155=$ mesal excision on tergite VIII and segment X with cerci in dorsal view, 156 = phallic organ with the endothecal spine pattern in left lateral view. 
Diagnosis. This new species having tapering harpago belongs to the Wormaldia triangulifera species group and having long microspine cluster with three stout spines belongs to the Wormaldia khourmai species complex. W. sima sp. nov. Most close to $W$. kera, but the speciation trait that is the head of segment $\mathrm{X}$ is arching not regular rounded. The spine shapes of the endotheca are different. The apicomesal excision on tergite VIII triangular without lateral lobes, not deep and wide subquadrangular with pronounced lateral lobes.

Description. Male (in alcohol). Small castanean brown animal. Sclerites medium brown, setal warts both on head and thorax and legs brown. Maxillary palp formula is I-II-IV-III-V. Forewing length $4 \mathrm{~mm}$. Spur formula is 244 .

Male genitalia. Tergite VIII with triangular mesal excision on the apical margin. Segment X characterized by narrowing apex in dorsal view, and by a smoothly arching dorsum of the head in lateral view; this arching is a continuation of the subapical excision; the ending is armed with probably specific pattern of sensory structures of sensilla basiconica (pegs) or sensilla coeloconica (pitted pegs). Cerci with rounded apex in lateral view; in dorsal view pronounced mesad turning apices well visible. Gonopods, with coxopodite longer than the tapering harpago. Phallic organ with eversible membranous endotheca containing short small-spine cluster and three spines; one spine is large robust, other two spines are small.

Etymology. sima, from "sima", in Hungarian refers to smooth arching dorsum of the lateral profile of the head on segment X.

\section{Wormaldia subnigra species complex}

According to our ranking criteria Wormaldia subnigra species complex having narrowing harpagones belongs to the Wormaldia triangulifera species group. This species complex is characterized by the combination (1) of the tapering harpago, (2) the terminal of segment $\mathrm{X}$ with dorsally concave capitate "head", with pronounced dorsal subapical pointed process.

\section{Wormaldia asterusia clade}

This species clade is characterized by the combination (1) of the tapering harpago, (2) the terminal of segment $\mathrm{X}$ with elongated and dorsally concave capitate "head", with pronounced dorsal subapical pointed process and (3) the endothecal spine pattern with just discernible cluster of small spines and with 2-4 individual spines.

\section{Wormaldia asterusia Malicky, 1972}

(Figures 157-159)

Wormaldia triangulifera asterusia Malicky, 1972:3132, "Holotypus ${ }^{\lambda}$ : Kreta, Asterusia-Gebirge südlich von Pigaidakia, 29.4.1971, leg. Malicky. Allotypoid $O$ und zahlreiche Paratypoide beider Geschlechter mit gleihen Daten; viele weitere Paratypoide von 13 anderen Fundorten aus ganz Kreta. Alle in meiner Sammlung." "die kretischen Exemplare unterschiden sich deutlich von den Vertretern der vier bisher bekannten Unterarten (triangulifera MCL.: Frankreich, beaumonti Schmid: Spanien, kimminsi Bots.: Mazedonien, moselyi Kimmins: Pyrenäen; Botosaneanu 1960, 1960a, Kimmins 1953), weshalb sie beschreiben und benannt wärden müssen."

Wormaldia thasica Malicky, 1983 in Çakin \& Malicky 1983. Malicky 2005a:549: "der Unterschied ist minimal", synonymised with $W$. asterusia Malicky, 1972.

Wormaldia asterusia Malicky, 1972: Malicky 2005b: 73-74, recorded from Greece: Chalkidiki, Thrakien, Crete, Thasos, Samothraki, Lesbos, Chios, Naxos, Ikaria, Samos, Kos, Rhodos, Karpathos. "Der Unterschied zwischen den nördlichen Populationen (thasica Malicky, 1983) und denen aus Kreta ist gering und rechtfertigt wohl doch kleinen eigenen Name."

Material examined. Paratype: Greece, Crete, Pigaidakia, $24^{\circ} 50^{\prime} \mathrm{E}, 34^{\circ} 57^{\prime} \mathrm{E}, 400 \mathrm{~m}$, 29.IV.1971, leg. H. Malicky (1 male, NMNHS). Crete, Hania nomos Prases, 18.V.1995, leg Á. Uherkovich \& S. Nógrádi (1 male, OPC). Crete, Rethymno regional unit, Axos,

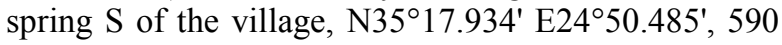
m, 2.IV.2013 leg. J. Kontschán, D. Murányi, T. Szederjesi, (3 males, HNHM).

\section{Wormaldia homora Oláh, 2014 stat. restit.}

$$
\text { (Figures 160-162) }
$$

Wormaldia homora Oláh, 2014:102-103: "most close to $W$. asterusia, but differs by having apex of seg- 


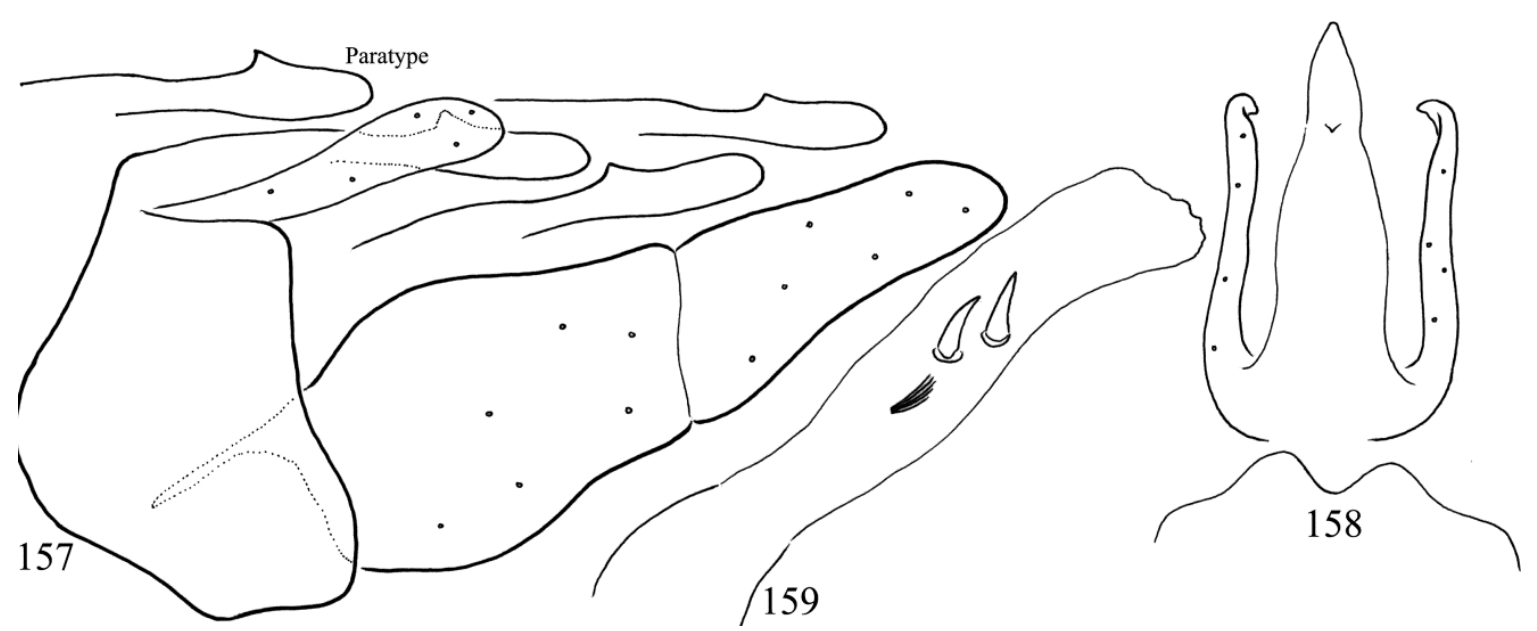

Figures 157-159. Wormaldia asterusia Malicky, 1972. $157=$ male genitalia in left lateral view, $158=$ mesal excision on tergite VIII and segment X with cerci in dorsal view, 159 = phallic organ with the endothecal spine pattern in left lateral view.

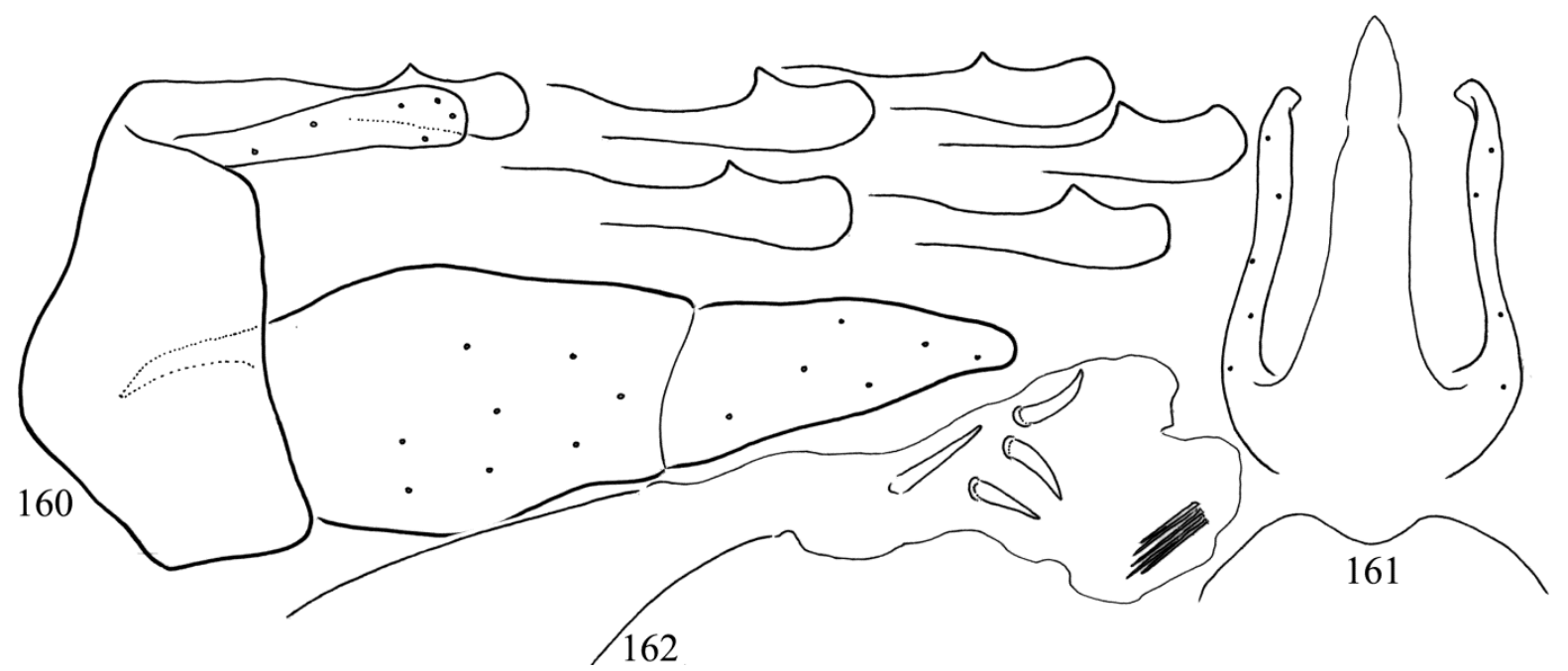

Figures 160-162. Wormaldia homora Oláh, 2014. 160 = male genitalia in left lateral view, $161=$ mesal excision on tergite VIII and segment $\mathrm{X}$ with cerci in dorsal view, 162 = phallic organ with the endothecal spine pattern in left lateral view.

ment X high, not low, apical portion of cerci truncate, not rounded in lateral view and the subapical mesal projection triangular, not rounded lobe in dorsal view; apices of harpago narrowing and downward curving, not broad; endothecal spine structure different."

Wormaldia triangulifera McLachlan, 1878: Kumanski 1969:177, Bulgaria, Pirin, below Vichren, 21.XI. 1967, (1 male, NMNHS). Having only a single male it was not possible to determine the subspecies. Misidentification!

Wormaldia triangulifera asterusia Malicky, 1972: Kumanski 1975:59, Bulgaria, Stara Planina, Belogradchik, 26.VI.1973, leg. A.C. (1 male, NMNHS). Bulgaria, Burgas, VII.1949, leg. A. P. (1 male,
NMNHS). Bulgaria, Micsurin (Tsarevo), 13.VII. 1974, light leg. C.Z. (1 male, NMNHS). Misidentification!

Wormaldia triangulifera asterusia Malicky, 1972: Kumanski \& Malicky 1976:103, "Material aus Bulgarien: Stara Planina, Umgebung von Belogradtschik, 26.VI.1973: 1 $\delta^{\Uparrow}$; Pirin-Gebirge, oberhalb der Hütte Wichren, 2300 m, 21.IX.1967: 1ð’; Küste des Schwarzen Meeres, Burgas, Juli 1949: $1{ }^{\lambda}$, leg. A. Popov; Strandscha-Gebirge, Katschul, 13.VII.1974, 1ठ̃, leg. Zagortschinov. Misidentification!

Wormaldia asterusia Malicky, 1972. Malicky 2018:43, "According to the description and the figures Wormaldia homora (Oláh, 2014) is without doubt 
W. asterusia, a species which lives from Crete in the south to the Bulgarian mountains (Malicky 2005:179), and is common in many sites. Its variability is well known. Wormaldia homora Oláh, 2014 = Wormaldia asterusia Malicky 1972, nov. syn.

Material examined. Holotype: Bulgaria: Eastern Rodopi, near Strazhetz, above the crossroad GugutkaKrumovgrad, 575m, N4121'11" E2550'35", 24.VII. 2012, at lights leg. S. Beshkov \& M. Beshkova, (1 male, NMNHS). Bulgaria, Pirin Mts. below Vichren, 21.XI.1967, leg. K. Kumanski (1 male, NMNHS). Bulgaria, Stara Planina, Belogradchik, 26.VI.1973, leg. A.C. (1 male, NMNHS). Bulgaria: Strandzha Mts., Katschul, 13.VII.1974, leg. Zagortschinov (1 male, NMNHS). Bulgaria: Central Stara Planina Mts. Tchamdzha Reserve near Hristo Danovo Village, 570 m, N4243'59" E2435'37", 31.VII.2014, leg. S. Beshkov (1male, NMNHBAS). Bulgaria, SW Bulgaria, Paril Pass between Alibotush (=Slavyanka) Mts. and S. Pirin Mts. between Paril and Nova Loccha Villages, 756 m, N41 ${ }^{\circ} 25^{\prime} 57^{\prime \prime}$ E2342'02", 17.VI.2013, leg. at lamps and light traps, S. Beshkov \& B. Zlatkov (1male, NMNHS).

Remarks. We have examined the type material of Wormaldia asterusia Malicky, 1972 together with newly collected material from two other regions of Crete and and compared again with the holotype of $W$. homora Oláh, 2014 and with other specimens collected from various mountains in Bulgaria: Pirin, Stara Planina, Strandzha, Alibotush Mountains.

The speciation trait that is the head of segment $\mathrm{X}$ is very stable in all the populations examined from various regions in Crete and from various mountains in Bulgaria. The head of segment $\mathrm{X}$ is short, high with very concave dorsum at $W$. homora and long, low and flat at $W$. asterusia. The endothecal spine pattern is composed of four stout spines in $W$. homora and composed only of two stout spines in $W$. asterusia. There are divergences in neutral traits as well: the apicomesal excision is wide without lateral lobes in $W$. homora and triangular with lateral lobes in $W$. asterusia; apices of harpago narrowing and downward curving in $W$. homora and broad in $W$. asterusia. Here we reinstate the species status of Wormaldia homora Oláh, 2014. Stat. Restit.

\section{Wormaldia subnigra clade}

This species clade is characterized by the combination (1) of the tapering harpago; (2) the terminal of segment $\mathrm{X}$ with elongated and dorsally concave capitate "head", with pronounced dorsal subapical pointed process and (3) of the endothecal spine pattern with just discernible cluster of small spines and with doubled and variously sized spines.

\section{Wormaldia granada Oláh \& Zamora-Muñoz, sp. nov.}

(Figures 163-165)

Material examined. Holotype, Spain, Granada, Monachil village, Cortijo de Diéchar, Rio Monachil, spindle: 30S, X-UTM: 459643, Y-UTM:4106471, $1416 \mathrm{~m}, 6 . X .2008$, leg. C. Zamora-Muñoz (1 male, OPC). Paratypes. Spain, Malaga, Canillas de Albaida village, Fabrica de la Luz, Rio de la Llanada de Turvilla, spindle: 30S, X-UTM: 413487, Y-UTM:408230, $720 \mathrm{~m}, 2-3 . V .2017$, leg. A. Tinaut (1 male, OPC). Spain, Malaga, Canillas de Albaida village, Fabrica de la Luz, Rio de la Llanada de Turvilla, spindle: $30 \mathrm{~S}, \mathrm{X}$ UTM: 413487, Y-UTM:408230, 720m, 15.V.2017, leg. A. Tinaut (1 male, OPC).

Diagnosis. This new species having tapering harpago belongs to the Wormaldia triangulifera species group and having the terminal of segment $\mathrm{X}$ with elongated and dorsally concave capitate "head" with pronounced dorsal subapical pointed process belongs to $W$. subnigra species complex, and having of rather specialised spine pattern of doubled spines belongs to $W$. subnigra species clade. Close to $W$. subnigra, but differs by having the speciation trait that is the head of segment $\mathrm{X}$ elongated very much, especially its dorsal concavity. This concavity is highly stable in all the examined populations both of $W$. granada and of W. subnigra.

Description. Male (in alcohol). Small castanean brown animal. Sclerites medium brown, setal warts both on head and thorax and legs brown. Maxillary palp formula is I-II-IV-III-V. Forewing length $4 \mathrm{~mm}$. Spur formula is 244 . 


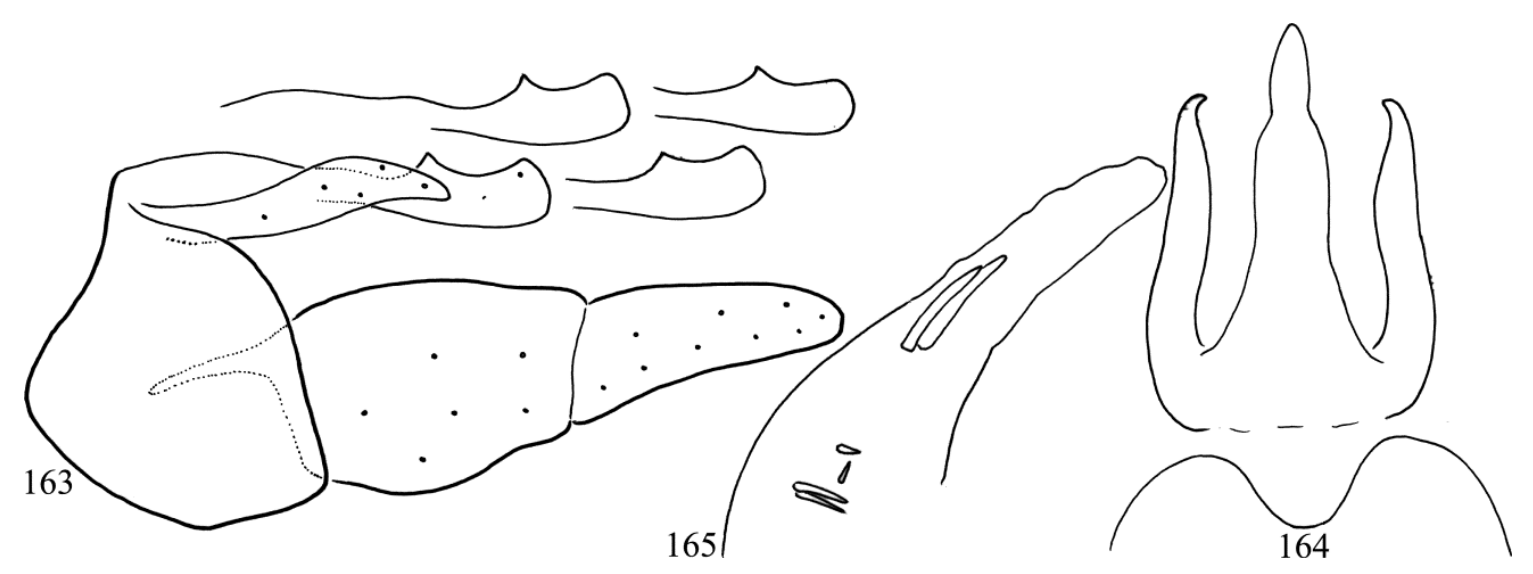

Figures 163-165. Wormaldia granada Oláh \& Zamora-Muñoz, sp. nov. Holotype: 163 = male genitalia in left lateral view with lateral profile of the speciation trait that is the head of segment $\mathrm{X}$ of three more paratypes from another populations, $164=$ mesal excision on tergite VIII and segment X with cerci in dorsal view, $165=$ phallic organ with the endothecal spine pattern in left lateral view.

Male genitalia. Tergite VIII with deep rounded mesal excision on the apical margin. Segment $\mathrm{X}$ characterized by narrowing apex in dorsal view, and by elongated head with long and deep dorsal concavity; the ending is armed with probably specific pattern of sensory structures of sensilla basiconica (pegs) or sensilla coeloconica (pitted pegs). Cerci with downward tapering apex in lateral view; in dorsal view apices slightly mesad directed. Gonopods, with coxopodite equal length to tapering harpago. Phallic organ with eversible membranous endotheca containing adhering doubled stout spines and two pairs of smaller spines.

\section{Etymology. Named after the type locality.}

\section{Wormaldia mediana McLachlan, 1878}

(Figures 166-168)

Material examined. France, Ardennes, Fleigneux, près de l'étang amont, sur la Hatrelle, 6.VIII.1999, sweeping leg. G. Coppa (1 male without phallic organ, OPC). France, Nièvre, Glux-en-Glenne, Yonne, 22. VII.2007, sweeping leg. G. Coppa (2 males, OPC). France, Var, La Martre, torrent Artuby pont romain, 14.VIII.2009, sweeping leg. G. Coppa (2 males, OPC).

\section{Wormaldia nielseni Moretti, 1981 stat. nov.}

(Figures 169-171)

Wormaldia mediana nielseni Moretti, 1981:173-174, „Differs from $W$. mediana in its longer harpago which is less curved at the lower margin and more densely spiney in the inner apical surface (a). The phallus endotheca has ten apical spines arranged in the form of a hair-pin, the last four being longer and irregularly oriented (b). The other spines and the basal indented sclerites as in $W$. mediana mediana (c).“

Material examined. Italy, Basilicata-Potenca, Maratea, Fiume Noce, N39.9574 ${ }^{\circ}$ E15.7709, 30 m, 22. VI.1998, light trap, leg. E. Bertuetti, P. Pantini \& M. Valle, det. Wormaldia mediana E. Bertuetti (4 males, 9 females, CNSMB; 2 males, OPC). Italy, Calabria-Cosenca, Spezzano Piccolo Fallistro, Fiume Neto, $\mathrm{N} 39.323^{\circ} \mathrm{E} 16.475^{\circ}, 1370 \mathrm{~m}, 21 . \mathrm{VIII} .2017$, light trap, leg. S. Scalercio \& M. Infusino, det. M. Valle (2017) as Wormaldia mediana nielseni (5 males, 1 female, CNSMB; 1 male, OPC). Italy, Sicilia-Messina, Roccella Valdemone, Torrente Licopeti-Contrada Revocato, $\mathrm{N} 37.95^{\circ} \mathrm{E} 15.015^{\circ}, 800 \mathrm{~m}, 7 . \mathrm{VII} .2016$, light trap, leg. R. Leotta, det. O. Lodovici (2016) as Wormaldia mediana nielseni (4 males, 2 females, CNSMB; 1 male, OPC).

\section{Wormaldia subnigra McLachlan, 1865}

(Figures 172-174)

Wormaldia triangulifera thasica Malicky, in Çakin \& Malicky, 1983: 270.

Wormaldia triangulifera thasica Malicky, 1983: Malicky 2005: 549, synonym of Wormaldia asterusia.

Wormaldia triangulifera thasica Malicky, 1983. Wormaldia asterusia is a sibling in the $W$. asterusia 
clade. This clade differs from the $W$. subnigra clade by having elongated concave apex of segment $\mathrm{X}$ and endothecal spine pattern without the twin of large spines. Moreover, the shape of the lateral profile of segment $\mathrm{X}$ and the endothecal spine pattern are identical with those of Wormaldia subnigra. Wormaldia triangulifera thasica is a synonym of $W$. subnigra. New Synonym.

Material examined. Albania, Vlore county, Dher$\mathrm{mi}$, Dhermi stream in the village, $139 \mathrm{~m}, \mathrm{~N} 40^{\circ} 09.330^{\prime}$ E19³8.374', 11.III.2008, leg. Sz. Czigány \& D. Murányi (2 males, $\mathrm{HNHM}$ ). Gjirokastër county, Finiq municipality, Syri i Kaltër spring, N39 55'23", E020¹1'30", 155 m, 3.XI.2018, leg. S. Beshkov \& A. Nahirnic (2 males, OPC). Bosnia \& Herzegovina, Sutjeska stream, Klobucarika tributary, 21-23.IX.1988, light/singled leg. J. Oláh (45 males, 2 females; OPC). Bulgaria, Eastern Rhodopi, Byala Reka River, Zhultichalskoto dere near Meden Buk Village, Ivaylovgrad District, 121m, N4122'48" E2601'40", 25.VII.2012, at lamps, light traps leg. S. Beshkov \& M. Beshkova, (2 males, OPC). Easterm Rhodopi Mts, Borovitza Valley, between Duzhdovnitza and Pudartzi, 359m, N41.68591 ${ }^{\circ}$, E25.282159 ${ }^{\circ}$ 13.VI.2018, leg. S. Beshkov, B. Zlatkov, R. Bekchiev (1 male, OPC). Croatia, Plitvicka Jezera N.P. Great Waterfall, 9.VII.2006, leg. L. Dányi (1 male HNHM). Czech Republic, Central Bohemia, Vůznice Reserve, Vůznice stream NW of Nižbor, 15.IX.2006, leg. P. Chvojka (4 males, NMPC; 1 male, OPC). England, Lancashire, Holme, 30.VIII. 1937, leg. W.G. Bainbridge (1 male, MMUE). England, Downham, Lancashire, 17.VII.1960, leg. A. Brindle (1 male, MMUE). Downham, Lancashire, 28.VIII.1932, leg. W. Britten (1 male, MMUE). Greece, Lamia, Sperchias, N38.878 ${ }^{\circ}$ E22.163ㅇ 185 m, 29.VII.2007, leg. M. Bálint (9 males, OPC). 3 km NE Loutro, N38.97, E21.2, $40^{\circ} \mathrm{m}, 30 . \mathrm{VII} .2007$, leg. M. Bálint (23 males, OPC). Italy, Friuli-Venezia, Giulia-Trieste, San Dorligo della Valle, torrente Rosandra, N45.6183을 E13.8737, 170 m, 18.VII.1996, light trap, leg. P. Pantini \& M. Valle (2 males, CNSMB). Montenegro, Sinjajevina Mts. Boan E 7km, brook and its gorge, $1184 \mathrm{~m}, \mathrm{~N} 42^{\circ} 55.616^{\prime} \mathrm{E} 19^{\circ} 16.333^{\prime}$, 10.X.2008, leg. L. Dányi, Z. Fehér, J. Kontschán \& D. Murányi (1 male HNHM). Norway, Vestfold Sandefjord: Andebu, Sukke, 59.363538 ${ }^{\circ} \mathrm{N} 10.134272^{\circ} \mathrm{E}, 13-$ 25.VIII.1974, leg. Arild Fjeldså (12 males, OPC). Serbia, Gamizigrad, Crni Timok River and its gallery, 183 m, N435'5'30.6" E220.7'46.2", 14.X. 2006, leg. L. Dányi, J. Kontschán \& D. Murányi (14 males, 3 females, HNHM). Spain, Cádiz province, Guadalete river basin, Arroyo Gaidóvar. 702m, Grazalema, 27. VI.1995, leg. A. Ruiz Garcia (4 males, OPC). Sweden, Dalarna, Malung-Sälans kommun, Österdalsälven, along road $70,9 \mathrm{~km}$ (air) WSW Idre, $61.8257^{\circ} \mathrm{N}$, $121.8789^{\circ} \mathrm{E}$, 7.VIII.2016, net, leg. K.A. Johanson (1 male, SNHM, C563, NHRS-TOBI 000003740).

Remarks. It is remarkable to recognise how stable is the lateral profile of the head of segment $\mathrm{X}$ that is the speciation trait on the entire distributional area sampled here in thirteen countries: Albania, Bosnia-Herzegovina, Bulgaria, Croatia, Czech Republic, England, Greece, Italy, Montenegro, Norway, Serbia, Spain, and Sweden. Of course every population or even every specimen has its own individual shape, but in a strictly integrated specific range of the species. In Wormaldia subnigra the dorsum of the head is short concave!

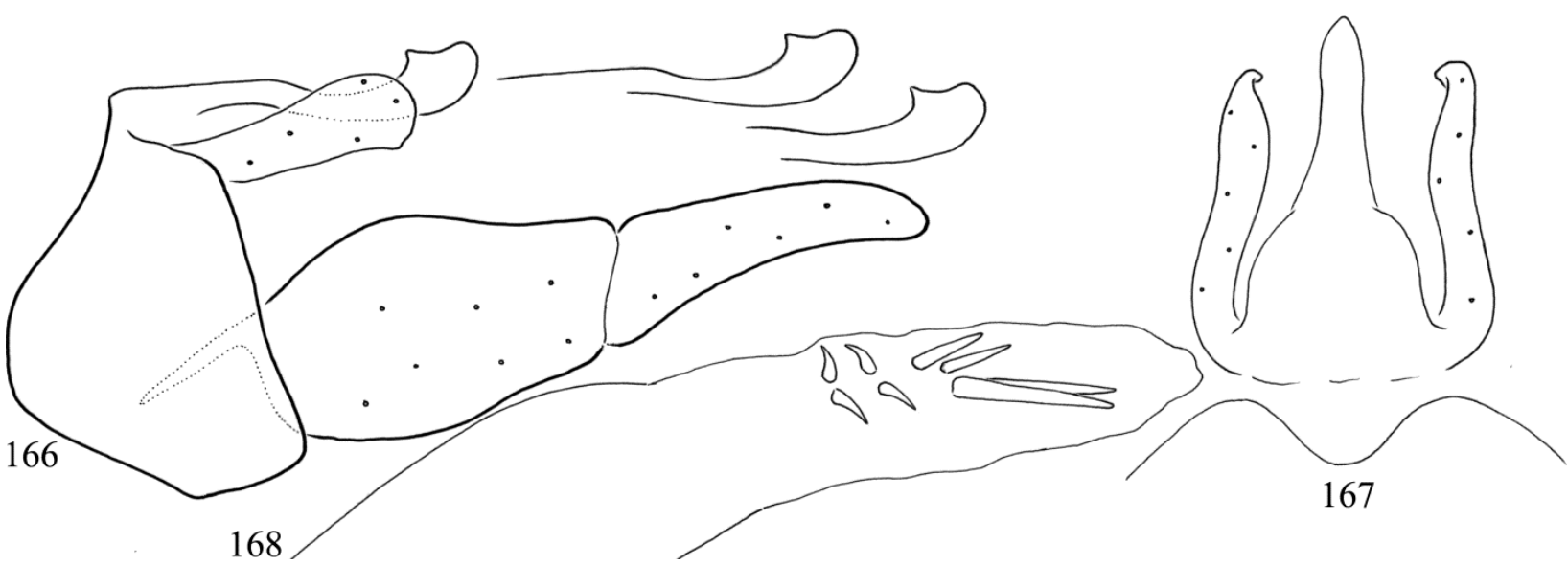

Figures 166-168. Wormaldia mediana McLachlan, 1878. $166=$ male genitalia in left lateral view with lateral profile of the speciation trait that is the head of segment $X$ of two more specimens from another populations, $167=$ mesal excision on tergite VIII and segment X with cerci in dorsal view, 168=phallic organ with the endothecal spine pattern in left lateral view. 


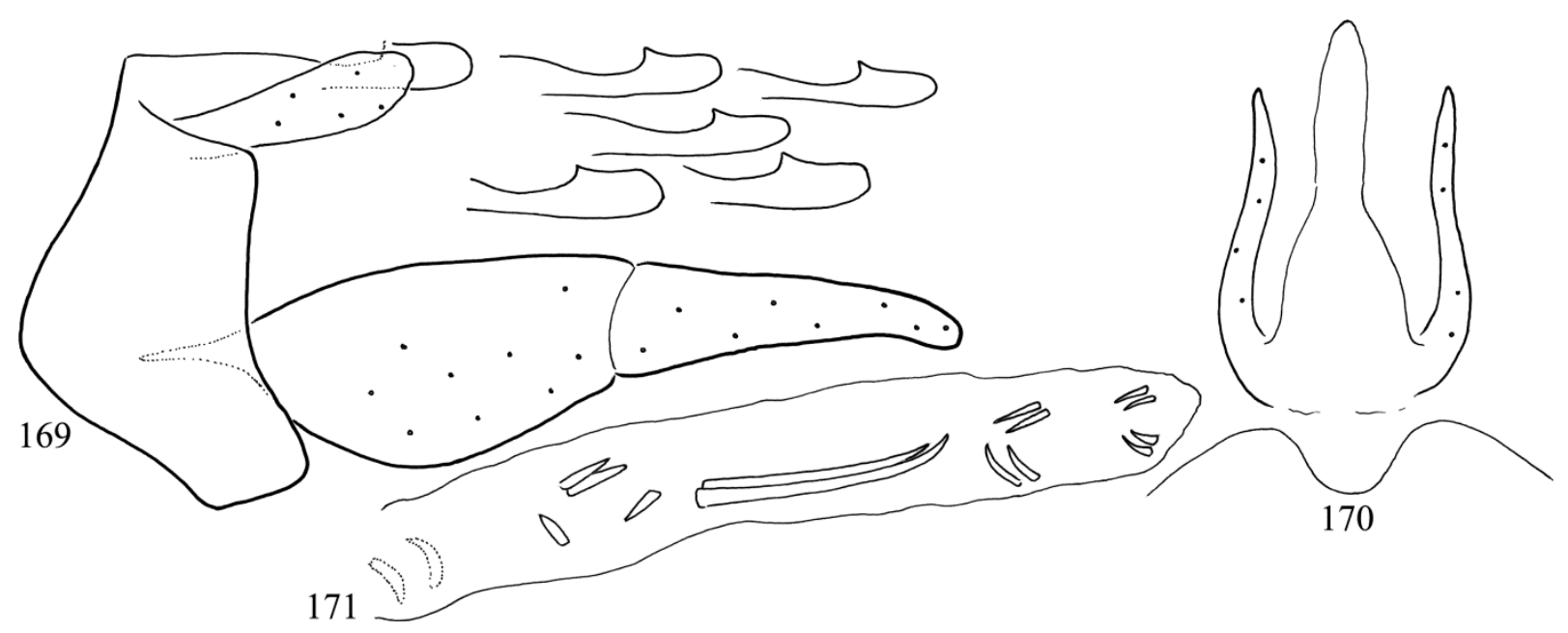

Figures 169-171. Wormaldia nielseni Moretti, 1981. 169 = male genitalia in left lateral view with lateral profile of the speciation trait that is the head of segment $\mathrm{X}$ of five more specimens from another populations, $170=$ mesal excision on tergite VIII and segment $\mathrm{X}$ with cerci in dorsal view, 171 = phallic organ with the endothecal spine pattern in left lateral view.

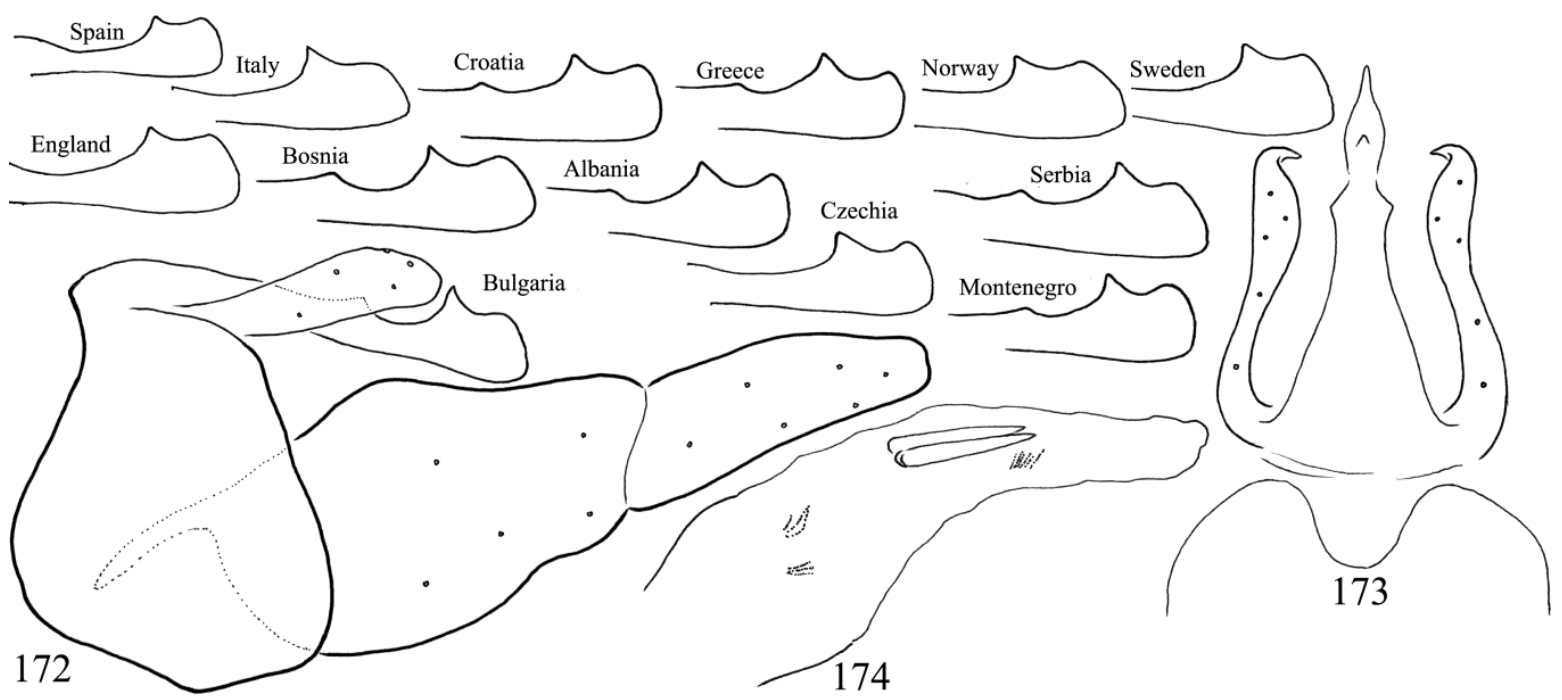

Figures 172-174. Wormaldia subnigra McLachlan, 1865. $172=$ male genitalia in left lateral view with lateral profile of the speciation trait that is the head of segment $X$ of populations from the entire distributional area, $173=$ mesal excision on tergite

VIII and segment X with cerci in dorsal view, 174=phallic organ with the endothecal spine pattern in left lateral view.

\section{Wormaldia vercorsica clade}

This species clade is characterized by the combination (1) of the tapering harpago, (2) the terminal of segment $\mathrm{X}$ with abbreviated, but dorsally concave capitate "head", with dorsal subapical pointed process and (3) the endothecal spine pattern without any cluster of small spines and with 4-6 individual stout spines. This clade is rather incongruent, discordant, chimeric, therefore uncertain to classify. Even the combination of tapering harpago and the concave dorsum of the head of segment $\mathrm{X}$ is not stable. Wormaldia ikizdere, W. malickyi, W. sucranae and the nominal species $W$. vercorsica are with concave dorsum of the head of segment X. The other two species $W$. gattolliati and $W$. telva sp. nov. are almost without any concavity, but has the combination of tapering harpago and four individual spines in the endotheca without any cluster of small spines. 


\section{Wormaldia gattolliati Malicky \& Graf, 2017}

(Figures 175-177)

Material examined. France, Alpes-Maritimes, Saorge, ru de Mairise, 440'46.6N ; 7²7'16.12 E, 1099 $\mathrm{m}$, in Mercantour National Park, 3.VII.2016, leg. G. Coppa (1 male, CPC; 1 male, OPC). Italy, PiemonteCuneo, Ormea, Rio Armella, N44.1639 E7.8821, 1000 m, 29.V.1998, leg. Museo Caffi BG, det. Bianchi as Wormaldia mediana (1 male, CNSMB).

\section{Wormaldia telva Oláh \& Johanson, sp. nov.}

(Figures 178-180)

Material examined. Holotype: Georgia, Marelisi southeast of Surami, N41 ${ }^{\circ} 56^{\prime 22}$.7" $^{\prime \prime}$ E04316'37.3", 693 $\mathrm{m}, 20 . \mathrm{V} .2012$, sweeping leg. O. Kurina (1 male, SMNH, NHRS-TOBI 000003744).

Diagnosis. This new species having tapering harpago belongs to the Wormaldia triangulifera species group. The combination of tapering harpago and four individual spines in the endotheca without any cluster of small spines relates this new species to $W$. vercorsica species clade. It is very close to $W$. gattolliati but distinguished by the higher lateral profile of the head of segment $\mathrm{X}$, the different shape pattern of the four spines as well as the shape of cerci.

Description. Male (in alcohol). Small castanean brown animal. Sclerites medium brown, setal warts both on head and thorax and legs brown. Maxillary palp formula is I-II-IV-III-V. Forewing length $4 \mathrm{~mm}$. Spur formula is 244 .

Male genitalia. Tergite VIII with very shallow mesal excision on the apical margin. Segment $X$ characterized by narrowing apex in dorsal view, and by the rounded elongated head rather high and with pronounced subapical dorsal pointed process; the ending is armed with probably specific pattern of sensory structures of sensilla basiconica (pegs) or sensilla coeloconica (pitted pegs). Cerci with downward tapering apex in lateral view; in dorsal view apices mesad directed. Gonopods, with coxopodite equal length to tapering harpago. Phallic organ with eversible membranous endotheca containing one stout, longer, simple spine and three stout and shorter spines with longitudinal edge.

Etymology. telva, from "telve", full of in Hungarian, refers to the convex dorsum of the apex of segment $\mathrm{X}$.

\section{Wormaldia triangulifera species complex}

This species complex is characterized by the combination (1) of the tapering harpago, (2) of the terminal of segment $\mathrm{X}$ with abbreviated capitate "head", with dorsal subapical pointed process and (3) of the endothecal spine pattern with a pronounced basal spine cluster accompanied by some individual variously sized spines.

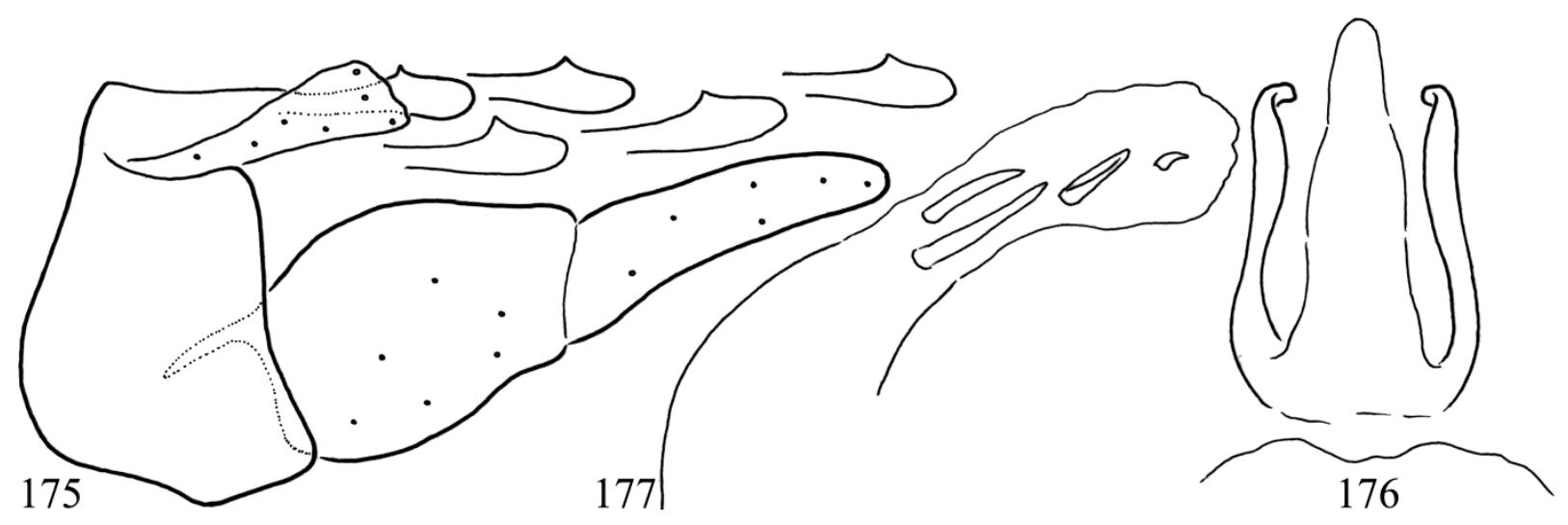

Figures 175-177. Wormaldia gattolliati Malicky \& Graf, 2017. $175=$ male genitalia in left lateral view with lateral profile of the speciation trait that is the head of segment X of populations from France and Italy, $176=$ mesal excision on tergite VIII and segment $\mathrm{X}$ with cerci in dorsal view, 177 = phallic organ with the endothecal spine pattern in left lateral view. 


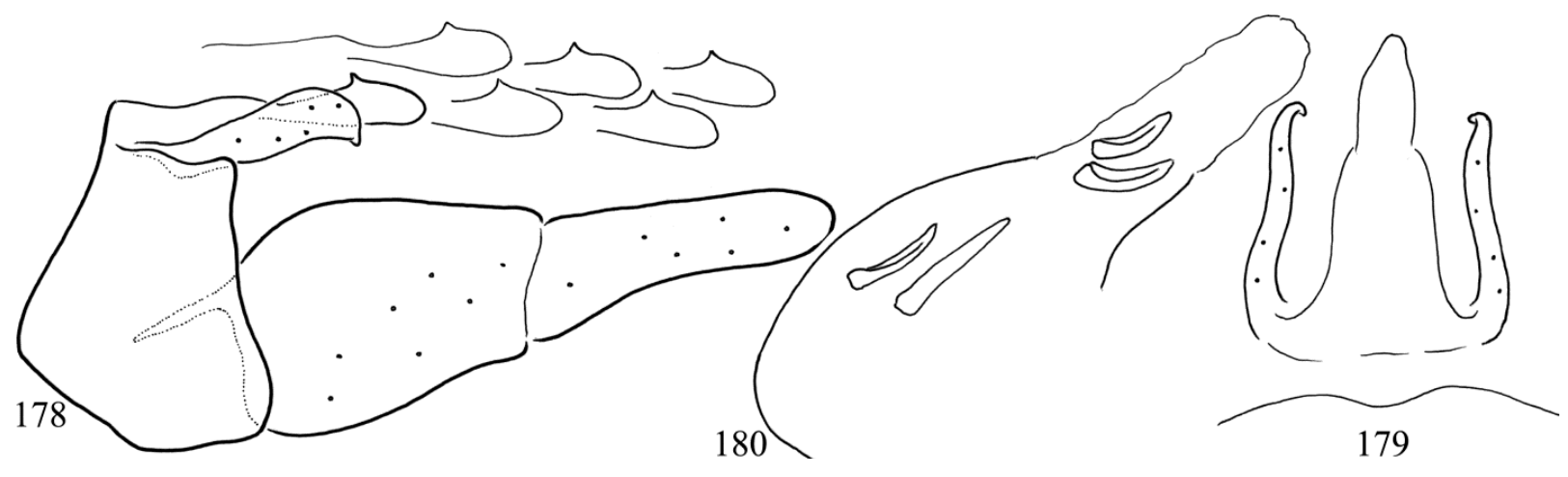

Figures 178-180. Wormaldia telva Oláh \& Johanson, sp. nov. Holotype: $163=$ male genitalia in left lateral view with lateral profile of the speciation trait that is the head of segment $\mathrm{X}$ redrawn five times, $164=$ mesal excision on tergite VIII and segment $X$ with cerci in dorsal view, 165=phallic organ with the endothecal spine pattern in left lateral view.

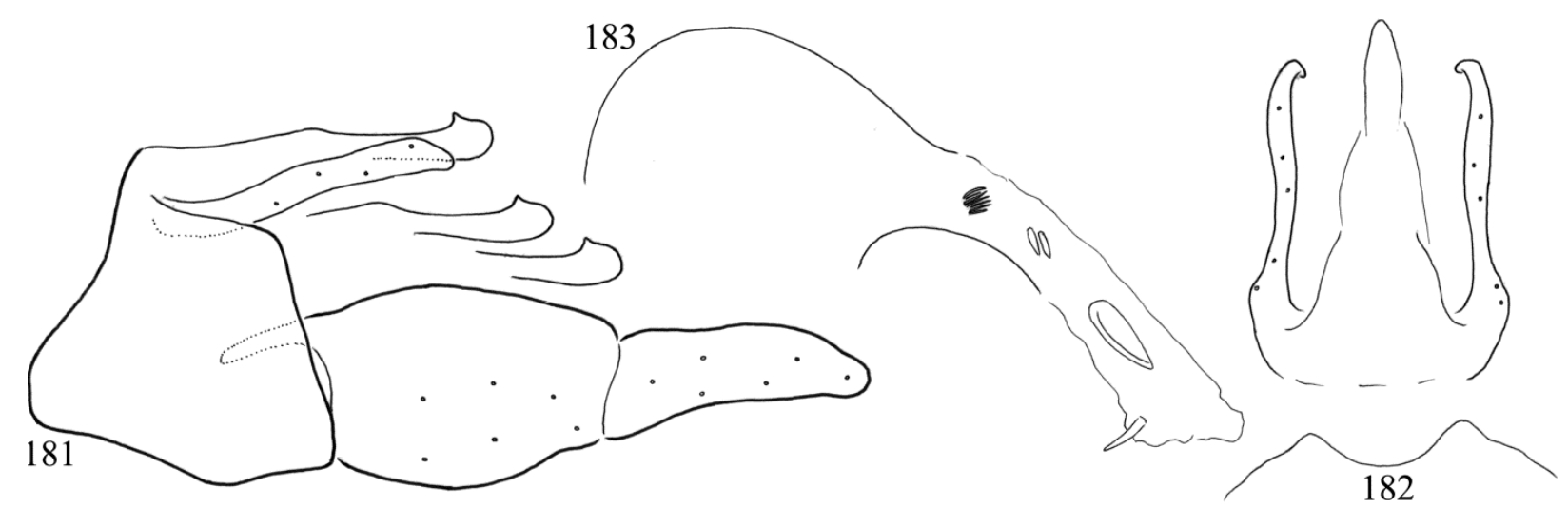

Figures 181-183. Wormaldia cantabrica Gonzalez \& Botosaneanu, 1983. $181=$ male genitalia in left lateral view with lateral profile of the speciation trait that is the head of segment $X$ of two more specimens from another populations, $182=$ mesal excision on tergite VIII and segment X with cerci in dorsal view, 183 = phallic organ with the endothecal spine pattern in left lateral view.

\section{Wormaldia cantabrica Gonzalez \& Botosaneanu, 1983}

(Figures 181-183)

Material examined. Paratypes: Spain, Sierra Segundera, Porto (Zamora), $1200 \mathrm{~m}, 18$. VII.1982, leg. M. Gonzalez (2 males, NBC-ZMAN). Spain, Sierra de Ancares, Lugo, Fuente del Barcal, 14.VIII.1984, leg. and det. M.A. Gonzalez (2 males, OPC).

\section{Wormaldia langohri Botosaneanu \& Giudicelli, 2001}

\section{(Figures 184-186)}

Material examined. France, Lozère, Le Pont-deMontvert, le Mazel route vers l'Hopital suintement, 26.V.2017, leg. G. Coppa (1 male, OPC).

\section{Wormaldia lusitanica Gonzalez \& Botosaneanu, 1983}

\section{(Figures 187-189)}

Material examined. Paratypes: Spain, El Rio (Orense), Rio Barbantiño, $480 \mathrm{~m}, 18 . \mathrm{V} .1974$, leg. M. Gonzalez (5 males, NBC-ZMAN). Spain, NW Spain, Galicia, Orense, Queguas, 14.VII.1988, leg. and det. M.A. Gonzalez (3 males, OPC). Portugal, Boticas Park-Nature e Biodiversity, Relva, 4. VI. 1980, leg. L. Terra, det. M. A. Gonzalez (2 males, OPC).

\section{Wormaldia moselyi Kimmins, 1953}

(Figures 190-192)

Material examined. France, Pyrenees Mts., Atlantic Pyrenees, Nivelle River system, 12-18.VII.1986, singled and light leg. J. Oláh (35 males, OPC). 


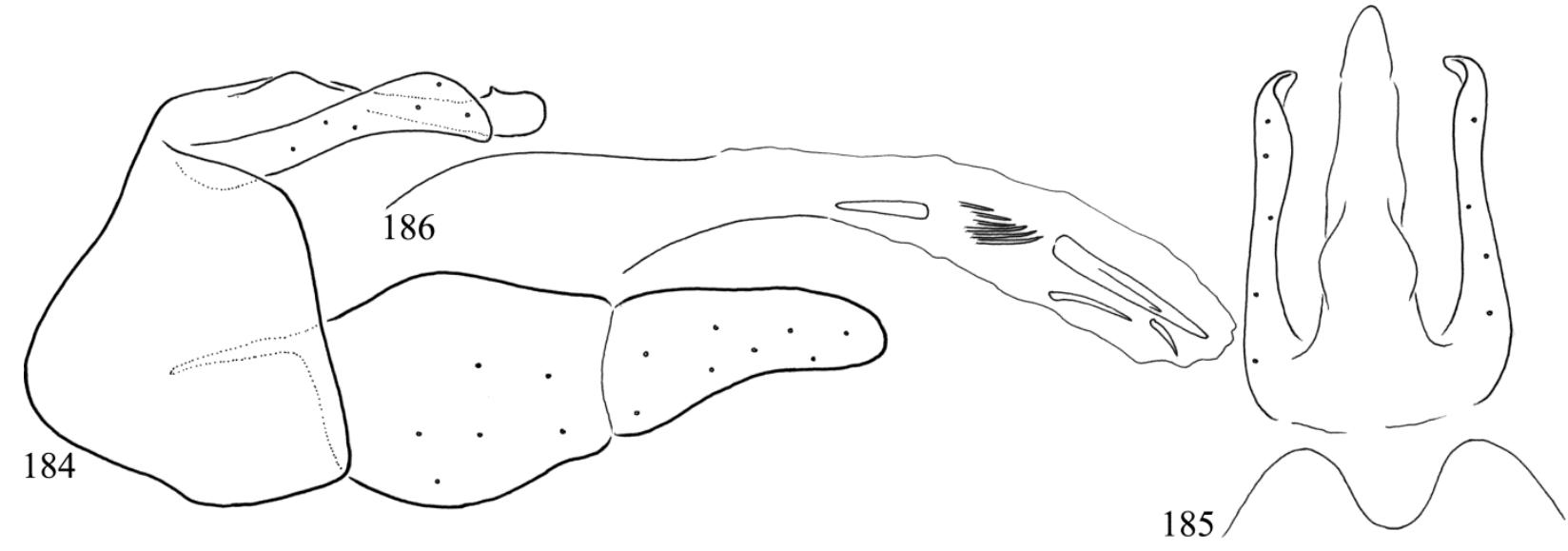

Figures 184-186. Wormaldia langohri Botosaneanu \& Giudicelli, 2001. $184=$ male genitalia in left lateral view, $185=$ mesal excision on tergite VIII and segment X with cerci in dorsal view, 186 =phallic organ with the endothecal spine pattern in left lateral view.

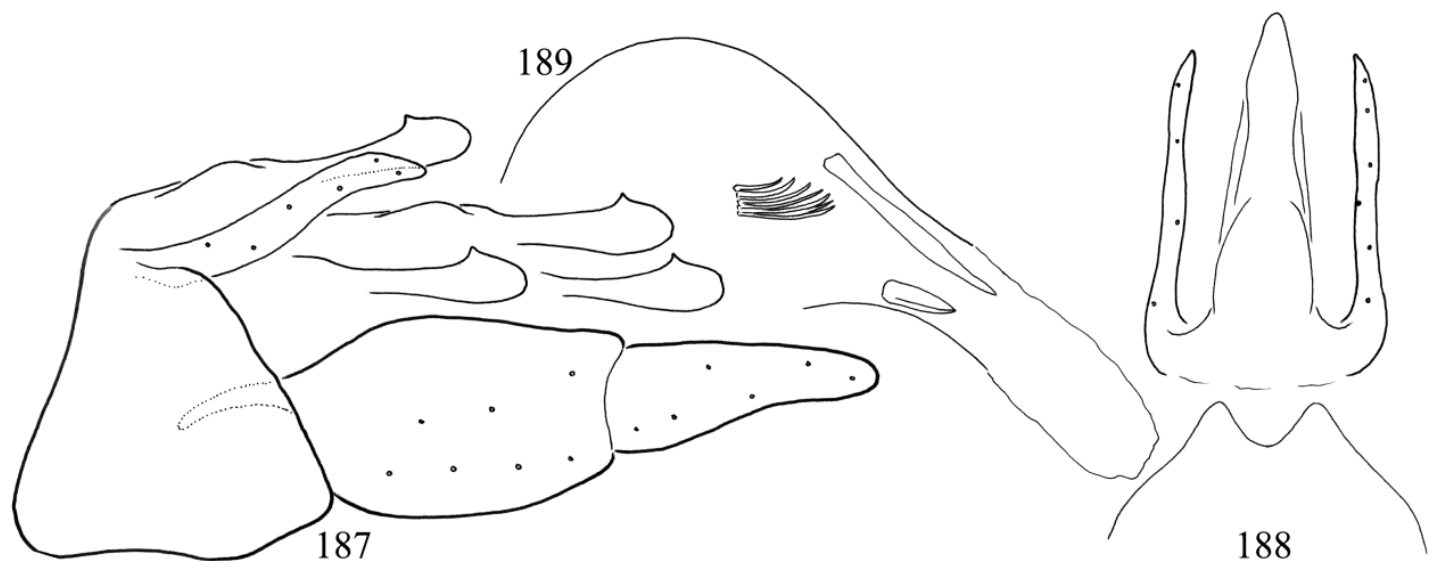

Figures 187-189. Wormaldia lusitanica Gonzalez \& Botosaneanu, 1983. 187 = male genitalia in left lateral view with lateral profile of the speciation trait that is the head of segment X of specimens from Spain and Portugal, $182=$ mesal excision on tergite VIII and segment X with cerci in dorsal view, 183 = phallic organ with the endothecal spine pattern in left lateral view.

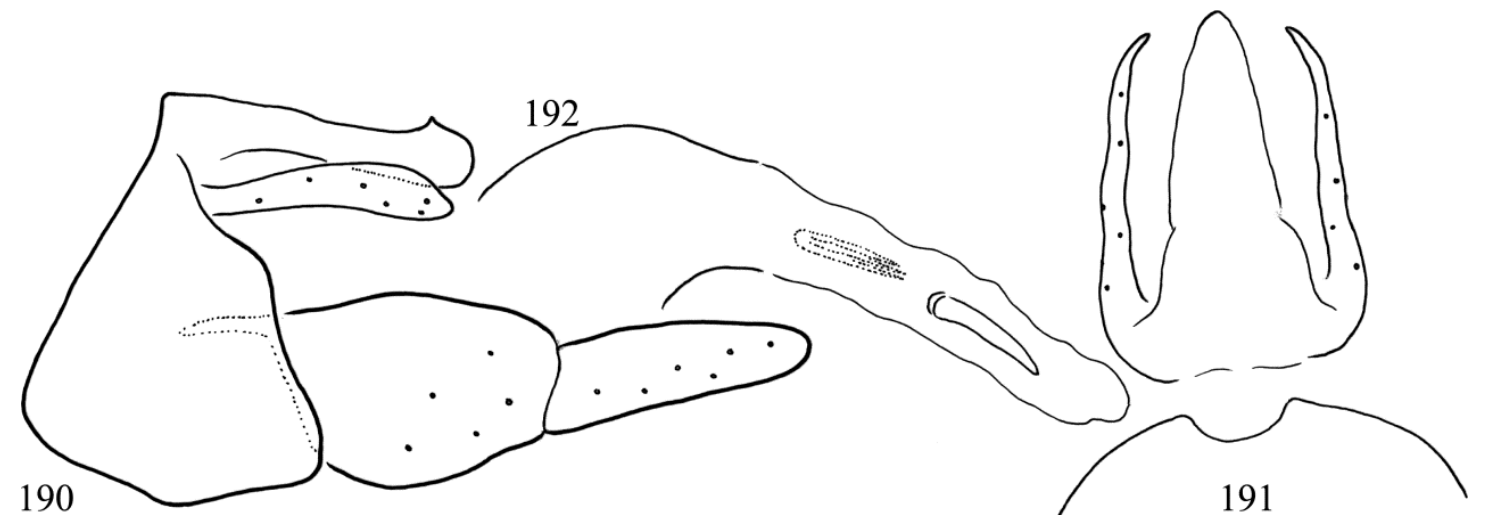

Figures 190-192. Wormaldia moselyi Kimmins, 1953. $190=$ male genitalia in left lateral view, 191=mesal excision on tergite VIII and segment X with cerci in dorsal view, 192 = phallic organ with the endothecal spine pattern in left lateral view. 


\section{Wormaldia triangulifera McLachlan, 1878}

(Figures 193-195)

Material examined. France, Citou, Aude, N43.408 ${ }^{\circ}$ E2.591 ${ }^{\circ}, 906$ m, 14.VII.2007, leg. M. Bálint (12 males OPC). France, Lespinassiére, N43.402 ${ }^{\circ}$ E2.532 ${ }^{\circ}, 450 \mathrm{~m}, 14$.VII.2007, leg. M. Bálint (5 males, 2 females, OPC). Spain, Lerida, Valle de Arán, Font de Savantan, 20. IX. 1986, leg. and det. M. A. Gonzalez (1 male, OPC).

\section{Wormaldia variegata species complex}

This species complex is characterized by the combination (1) of the tapering harpago, (2) of the terminal of segment $\mathrm{X}$ with less capitate, more hook-shaped head, with long or deep subapical depression without pronounced subapical pointed process and (3) of the endothecal spine pattern without spine cluster with some individual variously sized spines.

\section{Wormaldia maclachlani Kimmins, 1953}

(Figures 196-198)

Wormaldia mediana viganoi Moretti \& Taticchi, 1992: 254-256.

Wormaldia viganoi Moretti \& Taticchi, 1992: Malicky
2002:5, removed from $W$. mediana and raised to species rank with stat. nov.

Wormaldia viganoi Moretti \& Taticchi, 1992: Malicky 2005:550, synonymised with $W$. machlachlani.

Material examined. Italy, Piemonte-Biella, Quittengo, Rio Vait, N45.656 ${ }^{\circ} \mathrm{E} 8.0363^{\circ}, 1230 \mathrm{~m}$, 8.VIII. 2012, light trap, leg. O. Lodocici, P. Pantini, M. Valle, det. O. Lodovici (2012) as W. variegata maclachlani (3 males, 6 females, CNSMB; 2 males, OPC). Italy, Lombardia-Bergamo, Valgoglio, Valsanguigno, sorgente con igropetrico, $\mathrm{N} 45.9694^{\circ}$, E9.8897 $, 1250 \mathrm{~m}, 25$.VII. 2009 , light trap, leg. S. Cerea, det. S. Cerea (2009) as $W$. variegata maclachlani (1 male, 1 female, CNSMB; 1 male, OPC).

\section{Wormaldia variegata Mosely, 1930}

(Figures 199-201)

Wormaldia variegate denisi Moretti, 1981:174-175. "This subspecies is similar to $W$. variegate corsicana Vaillant, 1974.” New Synonym!

Material examined. France, Corse du Sud, Quensa, ru de tijeda pont D268, 16.VII.2011, leg. G. Coppa (1 male, OPC). Italy, Sardegne-Cagliari, Maracalagonis, Rio Dominugheddu sopra Geremea, N39.2516 E9.4266 ${ }^{\circ}, 380 \mathrm{~m}, 6 . X I I .2004$, leg. O. Lodovici \& P. Pantini (1 male, CNSMB; 1 male, OPC).

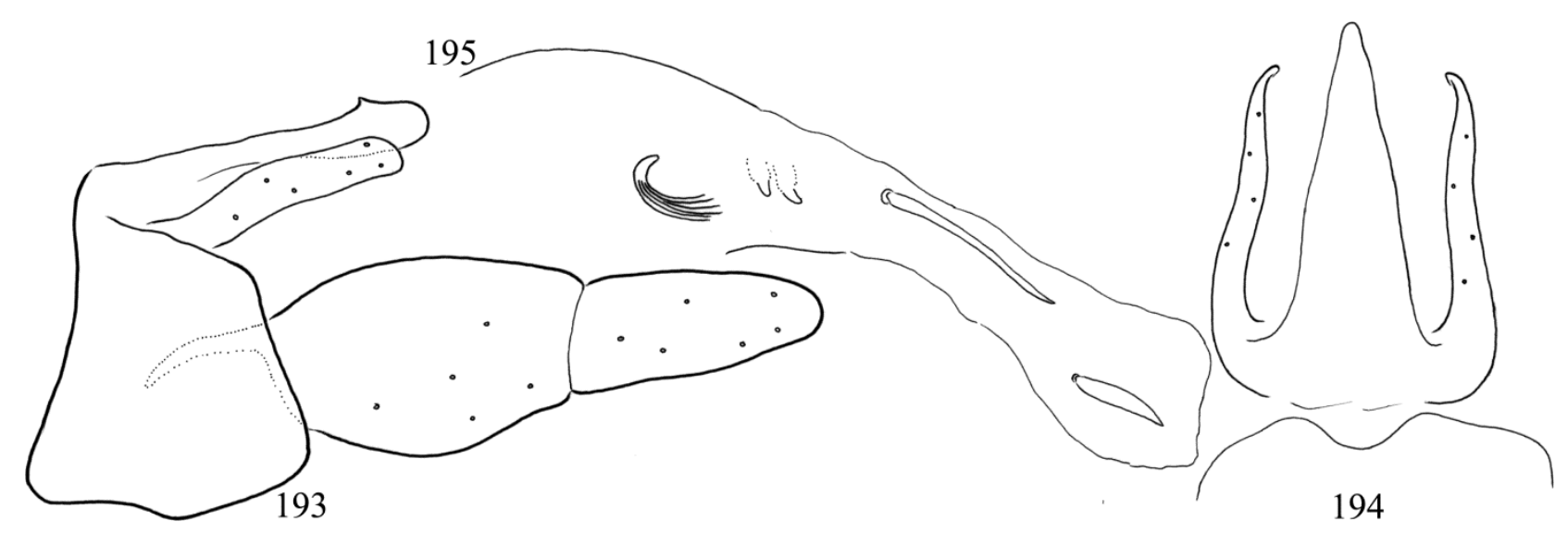

Figures 193-195. Wormaldia triangulifera McLachlan 1878. 193 = male genitalia in left lateral view, 194=mesal excision on tergite VIII and segment X with cerci in dorsal view, 195 = phallic organ with the endothecal pine pattern in left lateral view. 


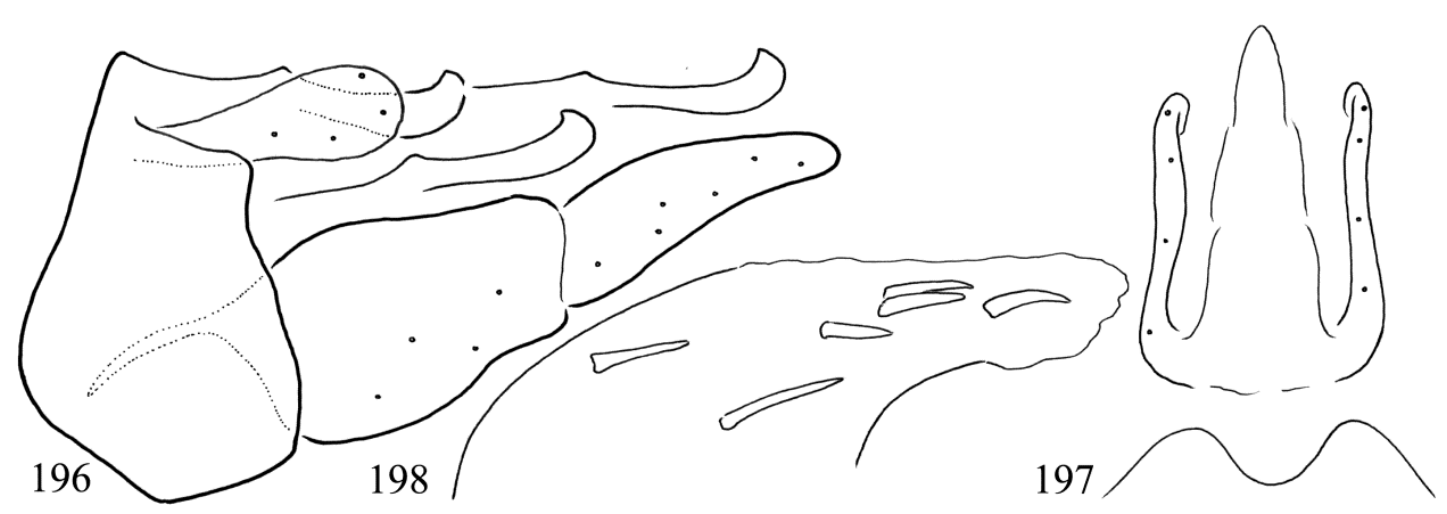

Figures 196-198. Wormaldia maclachlani Kimmins, 1953. 196 = male genitalia in left lateral view with lateral profile of the speciation trait that is the head of segment X of specimens from two populations, 197 = mesal excision on tergite VIII and segment X with cerci in dorsal view, 198 = phallic organ with the endothecal spine pattern in left lateral view.

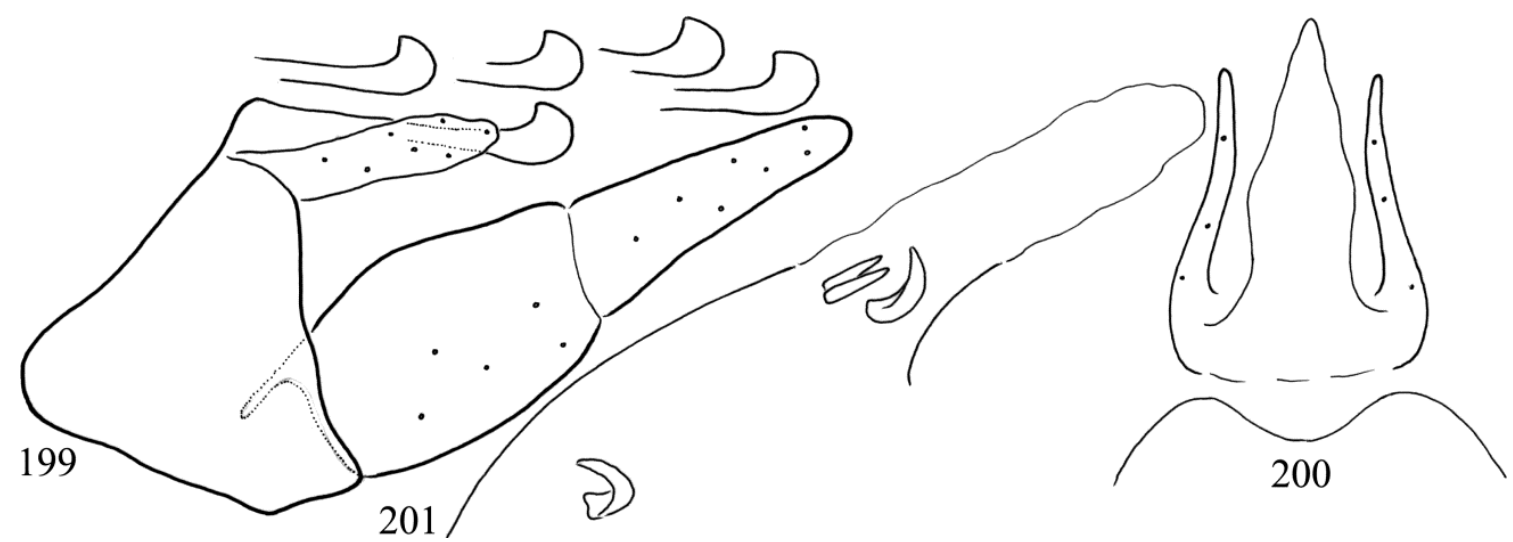

Figures 199-201. Wormaldia variegata Mosely, 1930. $199=$ male genitalia in left lateral view with lateral profile of the speciation trait that is the head of segment $X$ of specimens from France and Italy with redrawing, $200=$ mesal excision on tergite

VIII and segment X with cerci in dorsal view, 201 = phallic organ with the endothecal spine pattern in left lateral view.

Acknowledgements - We appreciate the crucial material provided to our studies by Marcos A. González, Department of Zoology and Physical Anthropology, Faculty of Biology, University of Santiago de Compostela, Spain; Carmen Zamora-Muñoz, Departamento de Zoologia, Universidad de Granada, Granada, Spain; Hallvard Elven, Naturhistorisk museum, Universitetet i Oslo; Tobias Malm, Department of Zoology, Swedish Museum of Natural History; Dmitri Logunov, The Manchester Museum, University of Manchester; Pasquale Ciliberti, Naturalis Biodiversity Center, Leiden, The Netherlands; Pavel Chvojka, Department of Entomology, National Museum, Praha, Czech Republic; the Museo Civico di Scienze Naturali "E. Caffi”, Bergamo, Italy and we are especially thankful to our cooperating colleagues Director Marco Valle and Dr. Omar Lodovici for their permanent support. We are grateful to Peter Neu for providing important comparative materials and for exchanging ideas.

\section{REFERENCES}

ANDERSEN, T. (1983): West Norwegian Wormaldia, with the description of Wormaldia occipitalis trifida ssp. nov. (Trich., Philopotamidae). Aquatic Insects, 5(4): 201-207.

Armitage, B.J. (1983): Diagnostic atlas of North American caddisfly adults. I. Philopotamidae. The Caddis Press (no pagination).

BAPteste, E., VAN IERSEl, L., JANKe, A., KelChNER, S., KelK, S., MCInerney, J.O., Morrison, D.A., NaKhleh, L., Steel, M., Stougie, L. \& WhitFIELD, J. (2013): Networks: expanding evolutionary thinking. Trends in Genetics, 29(8): 439-441. doi: $\underline{10.1016 / \text { j.tig. } 2013.05 .007}$ 
BotosaneAnu, L. (1960a): Trichoptères de Yougoslavie recueillis en 1955 par le D.F. Schmid. Deutsche Entomologische Zeitschrift, Neue Folge, 7(3): 261293.

Botosaneanu, L. (1960b): Révision de quelques espèces de Philopotamus Leach et de Wormaldia McL. (Trichoptera, Philopotamidae). Acta Societatis Entomologicae Ćechosloveniae, 57(3): 223-228.

Botosaneanu, L. (1989): Three western palaearctic caddisflies (Trichoptera) from the British Museum (Natural History) collections. Entomologist's Gazette, 40: 165-169.

BUENO, O. \& VICKERS, P. (2014): Is science inconsistent? Synthese, 191: 2887-2889. doi: $10.100 .1007 / \mathrm{s} 11229-014-0463-9$

BurkhardT, F. \& SECORD, J.A. (Eds.) (2016): The Correspondence of Charles Darwin. Vol. 23. Cambridge University Press, Cambridge, 840 pp.

ÇAKIN, F. \& MALICKY, H. (1983): Neue Köcherfliegen (Trichoptera) aus der Türkei und von der Balkanhalbinsel. Entomologische Zeitschrift, 93(18): 267270 .

DARWIN, C. (1859): On the origin of species by means of natural selection, or the preservation of favoured races in the struggle for life. John Murray, London, 502 pp. doi: $10.5962 /$ bhl.title.82303

DESALLE, R. (2016): What do our genes tell us about our past? Journal of Anthropological Science, 94: 193-200. doi: $10.4436 /$ jass. 94032

Doolittle, W.F. (1999): Phylogenetic classification and the universal tree. Science, 284: 2124-2128. doi: $10.1126 /$ science. 284.5423 .2124

Galtier, N. \& Daubin, V. (2008): Dealing with incongruence in phylogenomic analyses. Philosophical Transactions of the Royal Society B, 363: 40234029. doi: $10.1098 / \mathrm{rstb} .2008 .0144$

GRANT, V. (2003): Incongruence between cladistic and taxonomic systems. American Journal of Botany, 90(9):1263-1270. doi: 10.3732/ajb.90.9.1263

HAHN, M.W. \& NAKHLEH, L. (2015): Irrational exuberance for resolved species trees. Evolution, 70(1): 7-17. doi: $10.1111 /$ evo.12832

JACQUEMART, S. (1962): Deux sous-espéces de Womaldia (Trichopteres, Philopotamides). Bulletin Institut royal des Sciences naturelles de Belgique, 38(32): 1-8.
KIMMINS, D.E. (1953): A key to the European species of Wormaldia (Trichoptera, Philopotamidae), with descriptions of two new subspecies. The Annals and Magazine of Natural History, (twelfth Series) 6(71): 801-808.

KuHARA, N. (2005): A review of Wormaldia McLachlan (Trichoptera: Philopotamidae) in Japan, with redescriptions of eight species. In. TANIDA, K. \& Rossiter, A. (Eds.) Proceedings of the 11 th International Symposium on Trichoptera 2003, Osaka, p. 229-244.

KUMANSKI, K. (1969): Contribution a l'étude des Trichoptères en Bulgarie. II. Bulletin de l'Institut de Zoologie et Musée, 29: 175-181.

KUMANSKI, K. (1975): New trichopterological data from Bulgaria (Insecta, Trichoptera). Acta Zoologica Bulgarica, 2: 58-69.

KUMANSKI, K. (1979): To the knowledge of genus Wormaldia (Trichoptera, Philopotamidae) from the Balkans and Anatolia. Acta Zoologica Bulgarica, 12: $58-66$.

KUMANSKI, K. (1980): A contribution to the knowledge of Trichoptera (Insecta) of the Caucasus. Acta Zoologica Bulgarica, 14: 32-48.

KumAnsKI, K. (1985): Fauna Bulgarica 15, Trichoptera, Annulipalpia. Bulgarian Academy of Sciences, Sofia, 243 pp.

KUMANSKI, K. \& MALICKY, H. (1976): Beiträge zur Kenntnis der bulgarischen Köcherfliegen (Trichoptera). Polskie Pismo Entomologiczne, 46: 95-126.

Larsen, B.B, Miller, E.C., Rhodes, M.K. \& Wiens, J.J. (2017): Inordinate Fondness Multiplied and Redistributed: the Number of Species on Earth and the New Pie of Life. The Quarterly Review of Biology, 92(3): 229-265. doi: 10.1086/693564

LEE, M.S.Y. (2016): Count cryptic species in biodiversity tally. Nature, 534: 621. doi: 10.1038/534621a

MADDISON, W.P. (1997): Gene trees in species trees. Systematic Biology, 46(3): 523-536. doi: $\underline{10.1093 / \text { sysbio/46.3.523 }}$

MADDISON, W.P. (2006): Confounding asymmetries in evolutionary diversification and character change. Evolution, 60(8): 1743-1746. doi: 10.1111/j.0014$\underline{3820.2006 . t b 00517 . x}$

MALICKY, H. (1972): Weitere neue Arten und Fundorten von westpalearktischen Köcherfliegen (Tri 
choptera), vor allem aus dem östlichen Mediterrangebiet. Mitteilungen der entomologischen $\mathrm{Ge}$ sellschaft Basel, 22(2-3): 25-68.

MALICKY, H. (1977): Weitere neue und wenig bekannte mediterrane Köcherfliegen. Nachrichtenblatt der Bayerischen Entomologen, 26(4): 65-77.

MaLICKY, H. (2002): Einige Köcherfliegen (Trichoptera) aus Frankreich und Italien. Entomofauna. Zeitschrift für Entomologie, 23(1): 1-12.

MaLiCKY, H. (2004): Atlas of European Trichoptera. Second Edition. Springer, Dordrecht, The Netherlands, $359 \mathrm{pp}$.

MALICKY, H. (2005a): Ein kommentiertes Verzeichnis der Köcherfliegen (Trichoptera) Europas und des Mediterrangebietes. Linzer biologische Beitrage, 37(1): 533-596.

MaLICKY, H. (2005b): Die Köcherfliegen Griechenlands. Denisia, 17: 1-240.

MALICKY, H. (2014): Comments on two recently published papers on Cheumatopsyche (Hydropsychidae) and Chaetopteryx (Limnephilidae). Braueria (Lunz am See, Austria), 41: 51-53.

MALICKY, H. (2018): Synonyms of some European Trichoptera. Braueria (Lunz am See, Austria), 45: 43-45.

MCLACHLAN, R. (1865): Trichoptera Britannica. A monograph of British species of caddisflies. Transactions of the Entomological Society of London, (3)5: 1-184.

MickeVICH, M.F. (1978): Taxonomic congruence. Systematic Zoology, 27: 143-158. doi: $\underline{10.2307 / 2412969}$

MindELL, D.P. (2013): The Tree of Life: metaphore, model, and heuristic device. Systematic Biology, 62: 479-489. doi: $10.1093 /$ sysbio/sys 115

Moretti, G.P. (1981): New Trichoptera species and subspecies found in Italy. In. MORETTI G.P. (Ed.) Proceedings of the third International Symposium on Trichoptera, Dr W. Junk Publisher, The Hague. Series Entomologica, Vol. 20, p. 165-192.

MoretTi, G. \& TATICCHI, M.I. (1992): Ricerche tricotterologiche sulle Alpi Occidentali negli anni 1964-65. Descrizione di Wormaldia mediana viganoi ssp.n. Biogeographia, 16: 245-256.
Morrison, D.A. (2014): Is the Tree of Life the best metaphore, model, or heuristic for phylogenetics? Systematic Biology, 63(4): 628-638. doi: $\underline{10.1093 / \text { sysbio/syu026 }}$

Muñoz-Quesada F.J. \& Holzenthal, R.W. (2008): Revision of the Nearctic species of the caddisfly genus Wormaldia McLachlan (Trichoptera: Philopotamidae). Zootaxa, 1838: 1-75. doi: 10.11646/zootaxa.3998.1.1

NEU, P.J. (2015): Anmerkungen zu „Wormaldia occipitalis Pictet, 1834" (Trichoptera, Philopotaidae). Lauterbornia, 79: 107-124.

NG, J. \& SMITH, S.D. (2014): How traits shape trees: new approaches for detecting character state-dependent lineage diversification. Journal of Evolutionary Biology, 27(10): 2035-2045. doi: $10.1111 /$ jeb. 12460

NovÁK K. (1971): Beitrag zur Kenntnis der Köcherfliegen Bulgariens (Trichoptera). Acta Faunistica Entomologica Musei Nationalis Pragae, 14(162): 101-114.

OLÁH, J. (2010): New species and new species records of Palearctic Trichoptera in the Hungarian Natural History Museum. Annales historico-naturales Musei nationalis hungarici, 102: 65-117.

OlÁH, J. (2017a): Is the genus Potamophylax (Trichoptera: Limnephilidae) highly polymorphic? Acta Entomologica Musei Nationalis Pragae, 57(1): 253-257

OLÁH, J. (2017b): Trichoptera endemic in the Carpathian Basin and the adjacent areas. Folia Entomologica Hungarica, 78:111-255.

OlÁH, J., KovÁcs, T., Sivec, I., SzIVÁK, I. \& URBANIC, G. (2012): Seven new species in the Chaetopteryx rugulosa species group: applying the phylogenetic species concept and the sexual selection theory (Trichoptera, Limnephilidae). Folia Historico Naturalia Musei Matraensis, 36: 51-79.

OlÁH, J., Ibrahimi, H. \& KovÁcs, T. (2013a): The Chaetopteroides genus (Trichoptera, Limnephilidae) revised by fine structure analysis of parameres. Folia Historico Naturalia Musei Matraensis, 37: 93-108.

Oláh, J., Andersen, T., ChVojKa, P., Coppa, G., Graf, W., Ibrahimi, H., Lodovici, O., Previsic, A. \& VAlle, M. (2013b): The Potamophylax nigricornis group (Trichoptera, Limnephilidae): reso 
lution of phylogenetic species by fine structure analysis. Opuscula Zoologica, Budapest, 44(2): 167200.

OlÁH, J., ChVOJKA, T.P., COPPA, G., GrAF, W., IBrAHIMI, H., LOdOVICI, O., RuIZ Garcia, A., SÁINZBARIÁIN, M., VALle, M. \& ZAMORA-MuÑOZ, C. (2014): The genus Allogamus Schmid, 1955 (Trichoptera, Limnephilidae): revised by sexual selection-driven adaptive, non-neutral traits of the phallic organ. Opuscula Zoologica, Budapest, 45(1): 33-82.

OlÁH, J., ChVoJKa, T.P., COPPA, G., GOdunKO, R.J., LOdOVICI, O., MAJECKA, K., MAJECKI, J., SzCZESNY, B., URBANIC, G. \& VAlle, M. (2015): Limnephilid taxa revised by speciation traits: Rhadicoleptus, Isogamus, Melampophylax genera, Chaetopteryx rugulosa, Psilopteryx psorosa species groups, Drusu bolivari, Annitella kosciuszkii species complexes (Trichoptera, Limnephilidae). Opuscula Zoologica, Budapest, 46(1): 3-117. doi: 10.18348/opzool.2015.1.3

OlÁH, J. \& BeShKOV, S. (2016): New records of Trichoptera in the Balkan Peninsula and Romania, with description of new Rhyacophila sibling species by speciation traits. Folia Entomologica Hungarica, 77: 87-104.

OlÁH, J. ChVojka, P, Ciubuc, C., Coppa, G. \& IBrAHIMI, H. (2016): New incipent species under reinforcement in the Drusus discolor new species complex. Folia Historico-Naturalia Musei Matraensis, 39: 105-130.

OlÁH, J., BeshKov, S., ChVoJKa, T.P., Ciubuc, C., COPPA, G., IBRAHIMI, H., KovÁcs, T., MEY, W. \& OLÁH, J. jr. (2017): Revision of Drusinae subfamily (Trichoptera, Limnephilidae): divergence by paraproct and paramere, speciation in isolation by integration. Opuscula Zoologica, Budapest, 48(S1): 3228. doi: $10.18348 /$ opzool.2017.S1.3

OlÁH, J. \& OlÁH, J. jr. (2017): Fine phenomics applied to the Nectopsyche genus (Trichoptera). Species delineation by speciation traits. Opuscula Zoologica, Budapest, 48(2): 117-184 doi: 10.18348/opzool.2017.2.117

OLÁH J. \& KISS, O. (2018): Splitting by adaptive traits in the Rhyacophila obscura species group (Trichoptera, Rhyacophilidae). Opuscula Zoologica, Budapest, 49(2): 151-161. doi: 10.18348/opzool.2018.2.151
OlÁH, J., KovÁcs, T. \& IBRAHIMI, H. (2018): Agaphylax, a new limnephilid genus (Trichoptera) from the Balkan: Lineage ranking by adaptive paramere. Opuscula Zoologica, Budapest, 49(1): 77-89. doi: $\underline{10.18348 / \text { opzool.2018.1.77 }}$

Oláh, J., Andersen, T., Beshrov, S., Ciubuc, C., COPPA, G., IBRAHIMI, H., KovÁCs, T., OlÁH, J. jr. \& SZCZESNY, B. (2018): Unified phylogenetic species concept: taking subspecies and race out of science: postmodern theory applied to the Potamphylax cingulatus group (Trichoptera, Limnephilidae). Opuscula Zoologica, Budapest, 49(1): 3370. doi: $\underline{10.18348 / \text { opzool.2018.1.33 }}$

OlÁH, J. \& DE VRIES P.J. (2019): New Baliomorpha species (Trichoptera, Hydropsychidae) from Papua, Indonesia, with plesiomorphic state of phallic organ. Suara Serangga Papua (SUGAPA digital), 11(2): 87-93. doi: 10.19269/sugapa2019.11(2).05

RADOVANOVIC, M. (1932): Wormaldia subterranea $\mathrm{n}$. sp., eine neue, in den Höhlen Jugoslawiens aufgefundene Trichopteren-Art. Zoologischer Anzeiger, 100(3-4): 101-108.

Ross, H.H. (1956): Evolution and classification of the mountain caddisflies. The University of Illinois Press, Urbana, 213 pp.

SALTHE, S.N. (1991): Two forms of of hierarchy theory in Western discourses. International Journal of General Systems 18(3): 251-264. doi: $\underline{10.1080 / 03081079108935149}$

SIPAHILER, F. (2017): Variations in the male genitalia of Potamophylax nigricornis Pictet, 1934 in Turkey (Trichoptera, Limnephilidae). Braueria (Lunz am See, Austria), 44: 44.

SIPAHILER, F. (2018): Variations in the male genitalia of Hydropsyche acuta Martynov, 1909 and synonymy with Hydropsyche derek Oláh \& Kiss, 2015 (Trichoptera, Hydropsychidae). Braueria (Lunz am See, Austria), 45: 33-34.

SoBER, E. (2015): Is the scientific method a myth? Perspectives from the history and philosophy of science. Mètode Science Studies Journal, 5: 195199. doi: $10.7203 /$ metode. 84.3883

VAILlant, F. (1974): Quelques Trichoptères Philopotamidae de France et d'Algerie. Annales de la Société Entomologique de France (NS), 10: 969-985. 